\title{
POPULATION STATUS AND ECOLOGY OF TREMBLING ASPEN AND BLACK COTTONWOOD COMMUNITIES ON THE BLACKFEET INDIAN RESERVATION
}

\author{
Prepared for: \\ The Blackfeet Nation- Fish and Wildlife Department \\ and United States Fish and Wildlife Service
}

\author{
Prepared by: \\ Stephen V. Cooper, Vegetation Ecologist \\ Bonnie L. Heidel, Botanist \\ Montana Natural Heritage Program of the Natural Resource Information Systems \\ 1515 East $6^{\text {th }}$ Avenue \\ Helena, MT 59620-1800 \\ (C) 1997 Montana Natural Heritage Program \\ Challenge Cost-Share Agreement No. 14-48-0006-96-3034
}




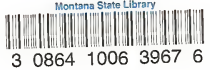




\section{(C) 1997 Montana Natural Heritage Program}

This document should be cited as follows:

Cooper, S. V. and B. L. Heidel. 1997. Population status and ecology of trembling aspen and black cottonwood communities on the Blackfeet Indian Reservation. Montana Natural Heritage Program, Helena, MT. 35 pp. plus appendices. 



\section{EXECUTIVE SUMMARY}

A combined botanical/ecological survey was conducted of the Blackfeet Indian Reservation's aspen parklands, targeting specifically moist to wet habitats thereof. Ecological and botanical data were entered into standard data bases, ECODATA for community attributes and BCD for botanical features, and analyzed by various multivariate techniques. The results should contribute to effective land management by providing for identification of unique habitats, especially those with wetland attributes, and placing information gathered into a statewide and national perspective.

Three plant associations, Populus tremuloides / Osmorhiza occidentalis, P. tremuloides / Cornus stolonifera, and P. tremuloides / Calamagrostis canadensis, are identified, described, rated for rarity and a vegetative key has been constructed for their field identification. One association, P. tremuloides /O. occidentalis, has exemplary representations on reservation lands and is highly likely to be relatively rare across the whole of its distribution; this report contains the most complete ecological description of this type and qualifies its uniqueness.

Structural and population analysis of these moist to wet aspen stands indicate most of them will continue to be dominated by $P$. tremuloides and Populus trichocarpa. These two species are replacing themselves but in certain situations the shade-tolerant Picea spp. and Abies lasiocarpa are entering stands and population trends indicate they will eventually become canopy dominants. Factors favoring the establishment of conifers in aspen stands were not explicitly identified, but cattle use is thought to play a part. Disease, decay and animal impacts to these stands are also described.

These vegetation types constitute a significant source of biodiversity. Though no TES plant species were located in any of the stands sampled, the within plot plant diversity was quite high (>30 species/plot) and the 167 plant species found in these three plant associations is a remarkably high figure for forested environments. For very similar communities and habitats it has been documented that they constitute crucial habitat for neotropical migrant bird species as well as other avians. These moister aspen types also provide an abundant grizzly bear (Ursus horribilis) herbaceous food source in the spring. 



\section{ACKNOWLEDGMENTS}

This project was facilitated by the coordination efforts of Ira Newbreast, Blackfeet Nation-Department of Fish and Wildlife and Mitch King, U. S. Fish and Wildlife Service. Cedron Jones, Montana Natural Heritage Program (MTNHP), digitized sampling locations, placed them in a GIS environment and generated appropriate map products. Scott Lee Chadde (MTNHP) provided guidance on data base structure and statistical procedures. Several Blackfeet Nation wetlands specialists made site visits and assisted in field work, including Mary Clare Weatherwax, Brian Fitzpatrick, and Joseph Butterfly. A challenge cost-share agreement between the U. S. Fish and Wildlife Service and the Montana Natural Heritage Program, augmented by a generous monetary contribution from The Nature Conservancy, funded this project. Blackfeet Nation personnel provided direction and coordination for the project and most especially permission to access their lands. 



\section{TABLE OF CONTENTS}

Page

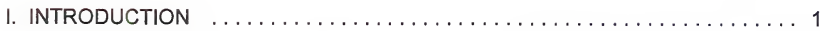

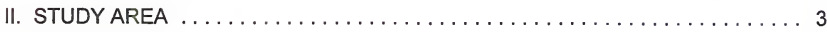

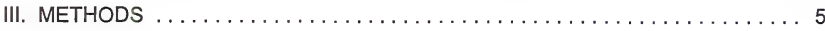

Data Collection . . . . . . . . . . . . . . . . . . . . . . . 5

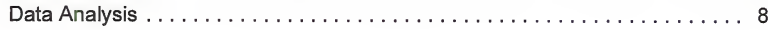

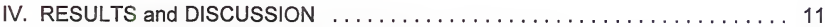

Community Ecology and Classification $\ldots \ldots \ldots \ldots \ldots \ldots \ldots \ldots \ldots \ldots \ldots \ldots$

Wetlands Determinations ........................... 24

Stand Structure and Successional Status . . . . . . . . . . . . . 28

Disease, Defect, and Pests . . . . . . . . . . . . . . . . . . 35

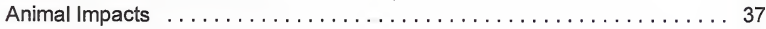

Rare Plant Species/Floristics . . . . . . . . . . . . . . . . . 39

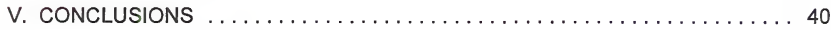

VI. LITERATURE CITED $\ldots \ldots \ldots \ldots \ldots \ldots \ldots \ldots \ldots \ldots \ldots \ldots \ldots \ldots \ldots, 42$

\section{FIGURES}

Figure 1. Trembling aspen ecology: ECODATA sampling plot locations on the Blackfeet Indian Reservation . . . . . . . . . . . . . . . . . 6

Figure 2. Two-dimensional ordination of 37 samples of trembling aspen-black cottonwood forests of the Blackfeet Indian Reservation .......... 12

Figure 3. Key to lifeform groups and selected deciduous forest types of the Blackfeet Indian Reservation . . . . . . . . . . . . . . . . . . 15

Figure 4. Plot of near maximum tree age and tree height (feet) versus tree

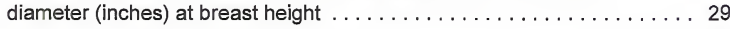

Figure 5. Frequency distributions by species for the largest size class represented within each stand, a) for Populus tremuloides, b) for Populus trichocarpa. 



\section{TABLES}

Table 1. Montana Plant Species of Special Concern documented to occur in or adjoining aspen habitat $\ldots \ldots \ldots \ldots \ldots \ldots \ldots \ldots \ldots \ldots \ldots$

Table 2. Wetland determination results; matrix of sample plots by jurisdictional wetland

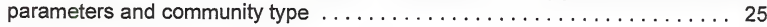

\section{APPENDICES}

Appendix A. Trembling aspen-black cottonwood communities: Cover synthesis, or "Stand" Table.

Appendix B. Trembling aspen-black cottonwood communities: Constancy-Cover Table (constancy, average abundance, and range of cover values).

Appendix C. Scatterplots of stem density by 2 inch size classes without regard to species.

Appendix D. Trembling aspen-black cottonwood tree populations by site and species diameter classes.

Appendix E. Trembling aspen-black cottonwood basal area by site, species, and sampling technique.

Appendix F. Vascular plant species occurring in trembling aspen-black cottonwood stands.

Appendix $G$. Application of comprehensive onsite determination method to selected trembling aspen-black cottonwood stands.

Appendix H. Montana Natural Heritage Program Community Survey Form.

Appendix I. Montana Natural Heritage Program Ocular Plant Species Data Form.

Appendix J. Annotated photographs documenting examples of the Populus tremuloides I Cornus stolonifera, P. tremuloides / Calalmagrostis canadensis and $P$. tremuloides / Osmorhiza occidentalis plant associations 


\section{POPULATION STATUS AND ECOLOGY OF \\ TREMBLING APEN AND BLACK COTTONWOOD COMMUNITIES \\ ON THE BLACKFEET INDIAN RESERVATION}

\section{INTRODUCTION}

Trembling aspen stands on the Blackfeet Indian Reservation (BIR) are among the most extensive, intact, and well-developed in the Northern Rocky Mountains, spanning a continuous gradient of terrestrial-to-wetland conditions in combination with black cottonwood. These stands are pivotal in evaluating the overall status and characteristics of aspen in the Northern Rockies, and their closely-associated wildlife resources.

Staff members of the Montana Natural Heritage Program, U.S. Fish and Wildlife Service, and the Fish and Wildlife Department of the Blackfeet Indian Nation, convened in late winter of 1996 to discuss research and inventory opportunities and priorities on the Blackfeet Indian Reservation (BIR). It was concurred that the wet communities dominated by trembling aspen (Populus tremuloides) and black cottonwood (Populus trichocarpa) are the most vulnerable and least well-documented, as well as having exceptionally high wildlife values. This in turn made them a priority for baseline characterization and management analysis covering wetland delimitation, successional status and condition.

Other studies have documented that the high wildlife values of aspen stands in general, and the wet aspen-cottonwood stands in particular, include disproportionately high Neotropical migrant breeding bird use compared to these stand's areal extent on the landscape, critical spring-early summer foraging grounds for grizzly bear, a buffered travel corridor and cover for big game between the extremes of the plains and the montane forests, and a structural landscape component that enhances overall wildlife diversity. Preliminary evidence has also been compiled that their uniqueness is also reflected in a diverse flora that includes rare plant species.

The seminal work on aspen types of BIR lands was conducted by Lynch (1955), but keys were not developed for the classification, leaving questions of delineation and distinction unresolved among the mesic-wet types. Among the documented plant community types was the trembling aspen - black cottonwood/ western sweet-cicely type (Populus tremuloides-Populus trichocarpa/Osmorhiza occidentalis) that is not known in other states and barely documented in Canada. It is identified as a plant community type which may be imperiled throughout its range (Grossman et al. 1994). It is treated as a wetland type by the Montana Riparian Association (Hansen et al. 1995), with meager information for differentiating it from terrestrial types. 

This study was set up to document the population status and ecology of trembling aspen and black cottonwood communities on the Blackfeet Indian Reservation as a baseline reference and management tool. Specifically, it addresses community classification, wetland delimitation, successional status, vigor and mortality conditions , and rare plant species. 



\section{STUDY AREA}

The aspen parkland of the Blackfeet Indian Reservation (BIR) consists of a distinct zone of parkland-fescue grassland mosaic between the eastern front of the Lewis Range of the Rocky Mountain Cordillera and the Great Plains. The parkland lies principally within the western edge of the BIR but on south slopes of narrow mountain valleys it advances into the eastern edge of adjacent Glacier National Park and on north-facing valley slopes it extends into the plains. This zone characterized by the prevalence of aspen usually does not much exceed 1,000 vertical feet, from 4,500 to 5,750 feet; exceptional stands can be found above and below these limits due to compensating factors (such as moist conditions associated with steep north-facing slopes of ridge systems set in a plains environment).

Its distribution largely corresponds with surficial geology, namely ground moraines deposited by Pleistocene Epoch, Wisconsin Stage glaciers (see maps in Lynch 1955). The St. Mary Glacier was fed by tributary glaciers from drainages in which now flow Divide, Red Eagle, Swiftcurrent, Boulder, and Kennedy Creeks and extended down the St. Mary Valley for some 36 miles. Marking the eastern extremity of the parkland are the lateral moraines on the western slopes of Saint Mary Ridge and which course up the St. Mary Valley to then extend northeastward, passing around the eastern end of Duck and Goose Lake.

Outwash fans consisting of cobbles and other coarse material formed at the Kennedy, Swiftcurrent, Wild and Divide Creeks. The bottom of the valley north of Lower Saint Mary Lake is filled with coarse material similar to that in the outwash fans. Where soils are well-developed or depth to water table is shallow these coarse materials support trembling aspen, but where a thin soil mantle prevails these coarse materials support Fescue (fescue)- and Agropyron (wheatgrass)-dominated grasslands.

From Hudson Bay Divide south, aspen parkland covers Wisconsin-age drift in the valley of Cutbank Creek to a short distance west of the Park boundary. South of Two Medicine Valley the parkland grades into a mixture of communities dominated by aspen, conifers, and herbaceous species. These vegetation types occupy ground moraines deposited by the Two Medicine Glacier, which was fed by glaciers originating in the Two Medicine Valley, Marias Pass, and in the valleys stretching south to Heart Butte.

The parkland, especially the moister sites, occupies primarily troughs and depressions in the ground moraine complex on the lower slopes of the valleys mentioned above and similar habitats at the head of the extensive Milk River drainage system. Argillites and limestones are the primary rock types contributing to the glacial till, whereas the bedrock appears to be Cretaceous sandstone. 

At the drier, plains portion of its distribution the aspen parkland rather abruptly gives way to rough fescue (Festuca scabrella)- and Idaho fescue ( $F$. idahoensis)-dominated grasslands of lower elevation, drier sites having thinner soils. Within predominantly forested landscape aspen stands also have relatively narrow transitions to conifer dominated stands. The conifer dominants range from Douglas-fir (Pseudotsuga menziesii) and lodgepole pine (Pinus contorta), typical of younger stands and drier environments, to subalpine fir (Abies lasiocarpa), Engelmann spruce (Picea engelmannil) and hybrid swarms of Engelmann with white spruce ( $P$. glauca) that characterize older stands and more mesic environments.

Potentially at least, two orders, nine Subgroups, and thirteen series are represented in our sampling, however, almost all of the soil mapping units that include aspen-black cottonwood are complexes and associations (e.g. Nettleton-Mikesell clay loams); thus it is not possible to distinguish even Orders at the plot level without fully describing a profile. The 37 sample plots occurred over 16 different soil mapping units, including one unit that was mapped as unequivocal wetland, Fresh Water Swamp.

A synopsis of the soils (their taxonomy) on which we found aspen parkland well developed is as follows:

\begin{tabular}{|c|c|c|}
\hline Order level & Subgroup level & Series \\
\hline Alfisols & Typic Cryoboralf & Loberg, Mikesell, Swifton \\
\hline Mollisols & $\begin{array}{l}\text { Pachic Cryoboroll } \\
\text { Typic Cryoboroll } \\
\text { Argic Pachic Cryoboroll } \\
\text { Typic Cryaquolls } \\
\text { Boralfic Cryoboroll } \\
\text { Argiaquix Xeric Argialboll } \\
\text { Calcic Cryoboroll } \\
\text { Typic Calciaquolls }\end{array}$ & $\begin{array}{l}\text { Adel, Gallatin, } \\
\text { Babb } \\
\text { Burnette } \\
\text { Gapo } \\
\text { Mord } \\
\text { Nettleton } \\
\text { Hanson, Raynesford } \\
\text { Bear Lake }\end{array}$ \\
\hline & & Fresh Water Swamp \\
\hline
\end{tabular}





\section{METHODS}

\section{Data Collection}

From previous field trips to forested lands of the BIR we were well acquainted with the distribution of trembling aspen and black cottonwood stands with respect to landscape position. Scanning orthophoto quads enabled us to identify areas with relatively extensive mature stands in relatively mesic landscape positions (more mesic than the average trembling aspen stand which generally occupies upland and hillslope positions). At areas of extensive trembling aspen we walked the landscape, focusing our search on positions known, or hypothesized, to be associated with a higher than average soil moisture regime. We sought homogeneity of vegetation composition and structure (across a given position) in selecting a representative plot within the stand. In general we attempted to sample stands that appeared to have a plant composition that indicated higher than average moisture regime. Sampling was spread along the whole of the Reservation's parkland (Figure 1) however, certain areas of extensive parkland, such as the vicinity of Kiowa, were more intensively sampled.

All sample plots were circular (37.2 ft radius), 1/10 acre in area. Information regarding location, abiotic site variables and plant composition (canopy coverage) was collected on the Natural Heritage Program Community Survey Form (Appendices G \& H). The Community Survey Form is a derivation of the General Plot Data and the Ocular Plant Species Data Forms employed by the USDA Forest Service (Northern Region) as a portion of their ECODATA (USDA 1996) community sampling package. We chose this approach because it provides a state-of-the-art relational data base structure for storage, retrieval, and export to analysis programs and is compatible with methods used by various government agencies collaborating with The Nature Conservancy.

The same size plot was also employed to determine diameter class distribution. Tree size and diameter classes employed were those defined by the U. S. Forest Services' Northern Region: seedlings (>6 in., $<4.5 \mathrm{ft}$. or $<1$ in. d.b.h.), saplings ( $>4.5 \mathrm{ft}$. or $>1$ in . and $<5$ in. d.b.h.), pole ( $>5$ in. to $<9.0$ in d.b.h.), mature ( $>9$ in. and $<14$ in. d.b.h.), large mature (> 14 in. d.b.h.). Initially all stems greater than 1 in. d.b.h. were counted by 1 inch diameter classes up to 6 in. in diameter and by 2 inch classes for trees with a greater than 6 in. diameter at breast height; later in the study we changed to tallying by 1 inch classes across all stem sizes, realizing this finer resolution did not slow the process and afforded a fine-scale documentation of size class distributions. The coverage of all vascular undergrowth species was tallied by the following canopy cover classes (percent values, see Daubenmire 1959): $0 ; \mathrm{T}=>0,<1 ; \mathrm{P}=21,<5 ; 1=25,<15$; $2=\geq 15,<25 ; 3=\geq 25,<35 ; 4=235,<45 ; 5=245,<55 ; 6=\geq 55,<65 ; 7=265,<75 ; 8=$ $275,<85 ; 9=\geq 85,<95 ; F=z 95$. Photographs to document the general aspect of stand structure and undergrowth composition were taken for all sites. An examination of the stand was conducted for any indicators of hydrological status (e.g. wrack lines, 

Trembling aspen ecology: ECODATA sampling plot locations on the Blackfeet Indian Reservation

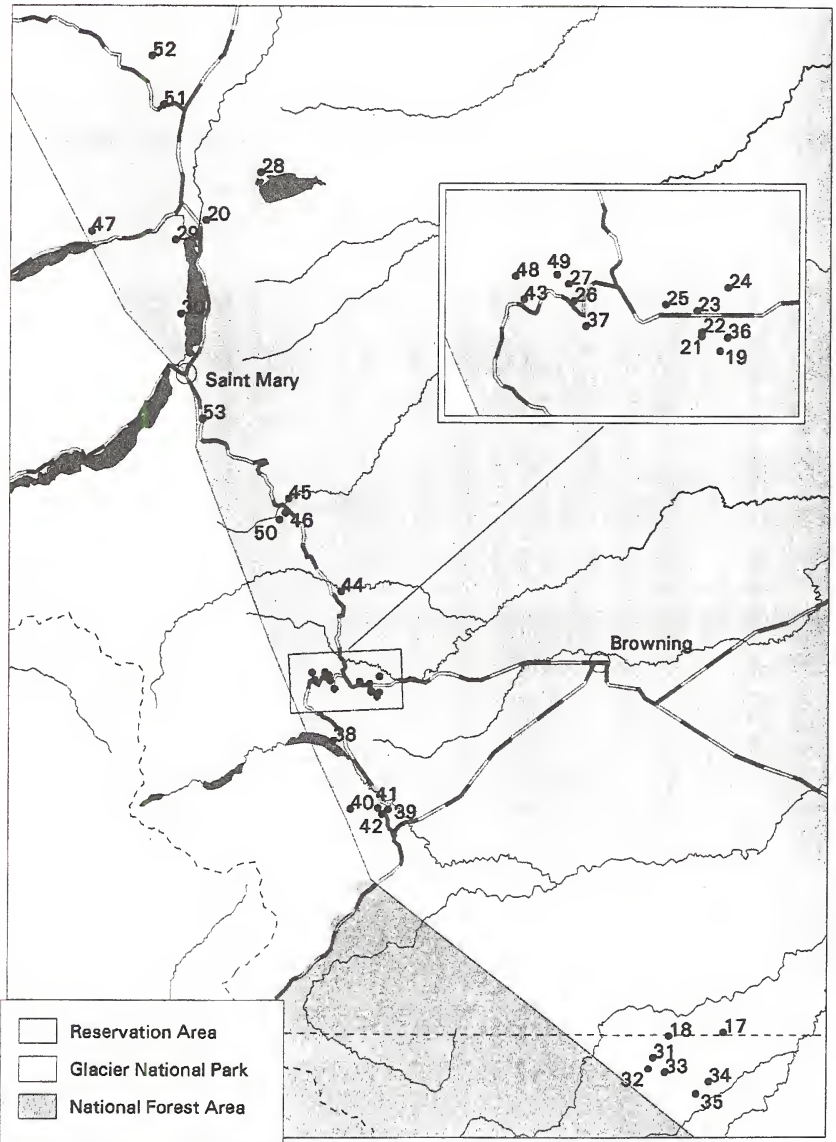

Montana Natural Heritage Program, March 17, 1997 

sediment deposits) as outlined by the "Corps of Engineers Wetlands Delineation Manual" (Environmental Laboratory 1987).

To gain insight as to the time of last major stand disturbance and general age class distribution information we attempted to core at least one healthy appearing (no conks, cankers or obvious signs of root rot) individual from the largest size class represented in the plot; if coring five or six trees on the plot did not result in countable cores we generally discontinued coring. Sometimes coring was continued when healthy specimens, of the same size class as those within the plot, were found outside the plot.

Soil pits were excavated only deep enough to yield information about the degree and extent of soil saturation; generally this was not deeper than $50 \mathrm{~cm}$. (20 inches). The features consistently noted were those pertinent to soil water regime: Distance to and height above water bodies, depth to free water or saturation, whether mottling and gleying were present, the depth at which these phenomena occurred and their strength of expression and depth of calcium carbonate accumulation. Other features were noted as appropriate to the determination of whether soils were hydric or not. Usually these features related to soil texture, shape and strength of peds, and distinctness of horizon boundaries. Soil samples were collected from the following depths (in $\mathrm{cm}$ ) $0-10,10-20$, and when warranted, 20-30. These samples were air dried and stored for later determination of soil color (hue and chroma), $\mathrm{pH}$ and conductivity. Soil series was determined from published soil maps (USDA Soil Conservation Service and USDI Bureau of Indian Affairs 1980) and compared against data collected in the field.

Field notes were taken on types and degrees of diseases and defects present on trees with primary guidance to field identification offered by Hiratsuka et al. (1995), Hagle et al. (1990) and Hinds (1985). Certain of the readily identifiable trunk rots, especially the presence of conks of Phellinus tremulae (syn. Fomes igniarius var. populinus, white trunk rot or white heart rot) and cankers, were systematically noted when tallying trees by size class.

Sensitive plant surveys were conducted on slightly fewer than half the plots inventoried, when a botanist familiar with all search images for sensitive, threatened, and endangered species accompanied the field staff. The process of sensitive species surveys can be summarized as follows; 1) Check for sensitive plant records in and around the project area, 2) Set species search targets and time frames for fieldwork, 3) Survey appropriate habitat at the crucial times of the growing season, 4) Collect information on any sensitive plant populations, also documenting them in photographs and specimens. The Biological Conservation Database (BCD) was searched for all records of special status features, including sensitive species; none of the these species are known to be associated with trembling aspen parkland or black cottonwood stands in Glacier County, although elsewhere Montana Plant Species of Species of Concern have been documented in or adjoining trembling aspen (Table 1). Many of 

Table 1. Montana Plant Species of Special Concern potentially occurring in or adjoining aspen habitat.

\begin{tabular}{|l|l|}
\hline $\begin{array}{l}\text { SPECIES COMMON NAME } \\
\text { (SCIENTIFIC NAME) }\end{array}$ & COUNTIES OF DISTRIBUTION \\
\hline $\begin{array}{l}\text { Round-leaved orchis } \\
\text { (Amerorchis rotundifolia) }\end{array}$ & $\begin{array}{l}\text { Flathead, Glacier, Lewis and Clark, Lincoln, } \\
\text { Pondera, Power, Teton }\end{array}$ \\
\hline $\begin{array}{l}\text { Short-styled columbine } \\
\text { (Aquilegia brevistyla) }\end{array}$ & Judith Basin, Sweetgrass \\
\hline $\begin{array}{l}\text { Sitka columbine } \\
\text { (Aquilegia formosa) }\end{array}$ & Beaverhead \\
\hline $\begin{array}{l}\text { Craw's sedge } \\
\text { (Carex crawei) }\end{array}$ & Cascade, Pondera, Power, Prairie, Teton \\
\hline $\begin{array}{l}\text { Yellow lady's-slipper } \\
\text { (Cypripedium parviflorum) }\end{array}$ & $\begin{array}{l}\text { Flathead, Gallatin, Granite, Judith Basin, } \\
\text { Lake, Lewis \& Clark, Lincoln, Missoula, }\end{array}$ \\
\hline $\begin{array}{l}\text { Buckler fern } \\
\text { (Dryopteris cristata) }\end{array}$ & Flathead, Lake, Missoula, Ravalli \\
\hline $\begin{array}{l}\text { Giant helleborine } \\
\text { (Epipactis gigantea) }\end{array}$ & $\begin{array}{l}\text { Carbon, Cascade, Flathead, Granite, Lake, } \\
\text { Madison, Power, Teton }\end{array}$ \\
\hline $\begin{array}{l}\text { Northern rattlesnake-plantain } \\
\text { (Goodyera repens) }\end{array}$ & $\begin{array}{l}\text { Fergus, Flathead, Judith Basin, Meagher, } \\
\text { Wheatland }\end{array}$ \\
\hline $\begin{array}{l}\text { Green gentian } \\
\text { (Halenia deflexa) }\end{array}$ & Flathead, Lincoln \\
\hline $\begin{array}{l}\text { Heart-leaved buttercup } \\
\text { (Ranunculus cardiophyllus) }\end{array}$ & Hill, Park \\
\hline $\begin{array}{l}\text { Northern buttercup } \\
\text { (Ranunculus pedatifidus) }\end{array}$ & Flathead, Glacier, Granite, Liberty, Toole \\
\hline $\begin{array}{l}\text { Desert groundsel } \\
\text { (Senecio ereophilus) }\end{array}$ & Sweetgrass, Toole \\
\hline
\end{tabular}



these species are boreal at their southern limits and the majority are also wetland species.

Throughout this report the scientific plant names are consistent with the older taxonomic treatment of Hitchcock and Cronquist (1984) to facilitate comparison and use with conventional range management, wildlife and forestry references. The scientific and common names of all species found in sampled plots and a rudimentary attempt to synonomize them with the most recent treatments are presented, alphabetized by scientific name within lifeform, in Appendix F.

\section{Data Analysis}

Analysis included a combination of ordination, to describe general patterns of communities in relation to environmental gradients, and classification, to ascertain and describe community types. Ordination was performed using detrended correspondence analysis (DECORANA, Hill 1979b); the input data being comprised of species cover (the midpoint values of cover classes) by stand. This is an indirect ordination method in that analysis is performed on the species data alone first and then environmental interpretation is made by superimposing environmental data on the ordination plots and examining the overlay for patterns and correlations. All default options were employed when running the ordination algorithm. Because only the moist to wet end of the moisture gradient for a single formation was the object of study, beta diversity was relatively low and there was no need to stratify the data set based on say, dominant lifeform in the undergrowth layer.

We also applied canonical correspondence analysis (CCA) using the computer program CANOCO (ter Braak 1988). CCA differs from the classical indirect ordination approach because it incorporates the correlation and regression between vegetation data and environmental factors within the ordination itself and thus constitutes a direct ordination. The input data consists of a data matrix of species by quadrats (stands) and a second matrix of environmental variables by quadrats (stands). The resulting ordination diagram thus expresses both the patterns of variation in floristic (or stand) composition and the principal relationships between species (or stands) and each of the environmental variables. We restricted our analysis to environmental variables that best capture wetland status, soil mottling and gleying; other important wetland variables expressing hydrologic status, e.g. depth to water table or saturation, registered too many zero observations for their use as statistical predictors.

Objective classification of vegetation was accomplished using two-way indicator species analysis (TWINSPAN, Hill 1979a); No data transformations were employed and all default options in the TWINSPAN algorithm were used, except that pseudospecies cut levels were set at 0, 5 and 20 percent cover. Insights into species occurrence and probable assemblages suggested by TWINSPAN were combined with field insights 

accumulated by the investigator and the plots were then subjectively grouped using STRATA (USDA Forest Service). Existing classifications of vegetation types, particularly of Montana wetland types (Hansen et al. 1995), dictated more the units we recognized than any single source of information. We attempted to make our interpretations fit existing modes of interpretation, in so far as the data would allow.

Analysis of stand structure consisted of plotting frequencies of live and dead stems by size classes to determine visually what might be occurring with tree populations. Patterns of ingrowth and mortality were compared with cases of typical patterns of forest reproduction and senescence (Oliver and Larson 1996) to determine the probable future course of BIR trembling aspen-black cottonwood parkland.

The "Corps of Engineers Wetlands Delineation Manual" (Environmental Laboratory 1987 ) is currently the document used to assess whether a putative wetland in fact meets wetland criteria. Information collected regarding hydrology, soils and vegetation was tabularized and weighed to determine whether the plot (and not necessarily the whole stand) met wetland criteria. 


\section{RESULTS and DISCUSSION}

\section{Community Ecology and Classification}

We present only the CCA ordination results (biplot) in Figure 2 as one result of data exploration, ascertaining the degree to which the only consistently measurable environmental variables were associated with stand (plot) position in vegetation and environmental space. The resulting ordination (biplot) is a product of the variability of the environmental data, the nominal variables gleying and mottling [positive associations GY, MY; negative associations ( $G N, M N)$, the ordinal variables chroma and value and the variability of the plot composition data (species coverages). The ordination diagram (Figure 2) expresses not only the patterns of variation in floristic composition but also demonstrates the principal relationships between stands of vegetation (plots) and each of the environmental variables. The arrows point in the direction of maximum change in these environmental variables across the diagram and their length is proportional to the magnitude of change in that direction.

Thus the plots of the upper left quadrant are positively associated with gleying (GY arrow) and mottling (MY arrow). Note that the plots of this quadrant are all underlined which indicates that they unequivocally satisfy the criteria for "jurisdictional wetland" (see page __ under Wetland Determinations section for explanation of "jurisdictional wetlands"). The arrows for low chroma and low value are weaker and indicate a few true wetlands plots (that have weak indications of mottling and gleying) that possess very dark (low value rating, high organic matter content) and grey soils (low chroma, lacking color). Soils of these plots (numbers $42,48,39$ ) were judged to be incipiently gleyed; they were not actually gleyed or mottled due to their developing on a coarsetextured substrate (sands and sandy loams) wherein gleying seldom develops due to adequate aeration (oxygen supply).

More than forty years have passed since Lynch (1955) conducted his study of trembling aspen "groveland" ecology. His study recognized three trembling aspen- or black cottonwood-dominated plant associations, Populus tremuloides/Symphoricarpos albus, Populus/Aster foliaceus, and Populus / Osmorhiza occidentalis. We have found the latter two of these associations, named only as Populus because they contained both $P$. tremuloides and $P$. trichocarpa, to be undifferentiable and propose merging them. We have documented two additional mesic to wetland associations, $P$. tremuloides / Calamagrostis canadensis and $P$. tremuloides/Cornus stolonifera as defined elsewhere by Hansen et al. (1995). We also observed three other trembling aspen-dominated forest associations in uplands, $P$. tremuloides / Calamagrostis rubescens, $P$. tremuloides / Carex geyeri (Mueggler 1988) and $P$. tremuloides / Symphoricarpos albus (Cooper and Pfister 1981). 



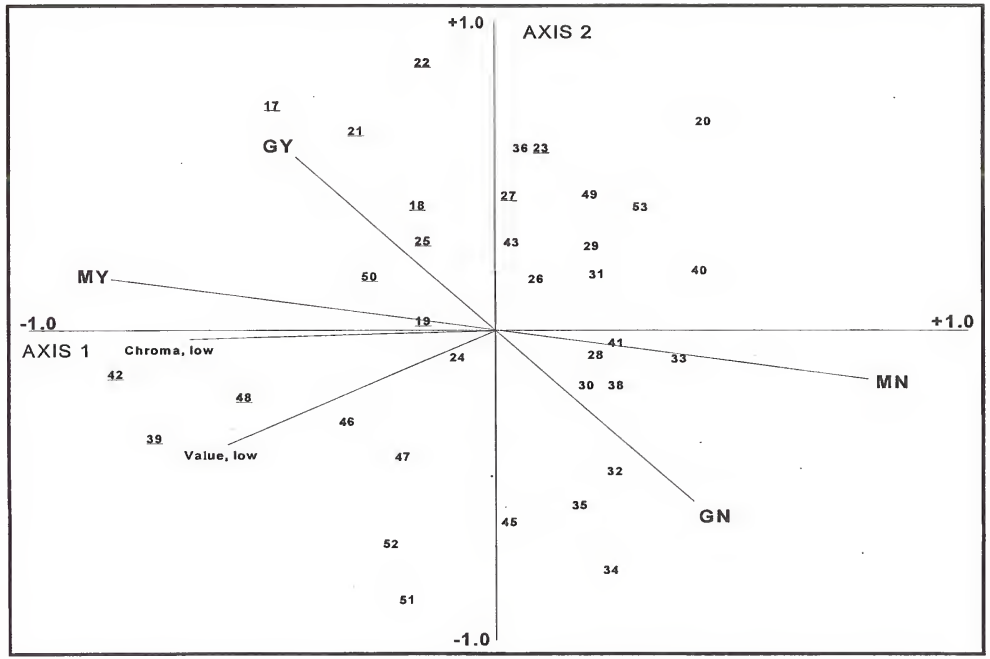

Figure 2. Sample plot/environment CCA biplot ordination of 37 of trembling aspen-black cottonwood-dominated forests of the Blackfeet Indian Reservation. The numbers represent the last two digits of ECODATA plot numbers; those underlined represent plots that unequivocally qualify as jurisdictional wetlands. Arrows representing each environmental variable (GY = Increasing Gleying, $\mathrm{GN}=$ Decreasing Gleying, $M Y=$ Increasing Mottling, $M N=$ Decreasing Mottling) point in the direction of maximum change in that variable across the diagram; the arrow's length is proportional to proportional to the magnitude of change in that direction. 

Lynch did not provide a key for plant association identification. Had he attempted to do so, he well may have experienced the difficulty we encountered in trying to separate his types on the landscape. We often encountered stands of pure $P$. tremuloides with Symphoricarpos albus dominant in the undergrowth, but mesic- to wet-site indicators (e. g. Angelica arguta, Geum macrophyllum, Viola canadensis, and Calamagrostis canadensis) also present and occasionally abundant. Is this a $P$. tremuloides/S. albus or a $P$. tremuloides/O. occidentalis plant association? Lynch did not employ the indicator concept, that the coverage or mere presence of certain plants is indicative of certain site conditions. Building upon Lynch's work and operating from a much expanded data base of vegetation stands and soils information we are proposing a revision of aspen and black cottonwood synecology for this area. For instance, Lynch did not note finding Angelica arguta, Festuca subulata or Schizachne purpurascens, all of which are important components of many stands we sampled; his sampling intensity or time of sampling was such that these species went unrepresented in the data base. He listed 36 species occurring in the $P$. tremuloides/Osmorhiza occidentalis p.a., whereas we have documented, based on 18 more plots than Lynch sampled, an additional 111 species for roughly the same portion of the environmental gradient. Our revision is in the best tradition of "successive approximation" (Poore 1962) that holds ecological conceptions regarding an area can be fine-tuned with additional sampling and analysis as an incremental approach to the most appropriate description or model.

We chose to focus on the wetter end of the moisture gradient represented by the Populus/O. occidentalis, Populus/A. foliaceus plant associations because these appeared to be problem areas for type recognition. Lynch recognized the importance of these two plant associations being capable of supporting both $P$. trichocarpa and $P$. tremuloides. He differentiated these two community types based on species dominance in the undergrowth layer, with the stands having greater importance (a higher "index value $^{\text {"1) }}$ ) for a suite of species defining a particular plant association and distinguishing it from other stand groupings with other suites of species having high index values .

Our analysis indicates that whatever composition might be considered typical for the Populus/Aster foliaceus p.a. is not borne out in the ordinations (Figure 2); there is no cluster of stands within the ordination that would be defined by the $A$. foliaceus union of species as described by Lynch (1955). Lynch characterizes the landforms or positions occupied by both Populus-dominated plant associations as having considerable overlap, including inter-morainal troughs and depressions in glacial drift. Because no indicator species or suite of species or environmental parameters could be identified as unique to this type it was merged with what Lynch termed Populus / Osmorhiza occidentalis and Cooper and Pfister (1981) described as Populus tremuloides-Populus trichocarpa / O. occidentalis. Populus trichocarpa is recognized in the latter association as an important and distinctive component. In this report we have equated it to the name $P$. tremuloides / Osmorhiza occidentalis following Hansen et al (1995), who dropped the dual tree designation in their statewide monograph of wetland community 

types. We have also accepted the lead of Hansen et al. (1995) in placing $P$.

tremuloides before $P$. trichocarpa in the key to plant communities. However, judging by our data and that of others, we perceive that $P$. trichocarpa is more strongly associated with hydric conditions than is $P$. tremuloides and therefore should come first in the key. Hansen et al [1995] have generally constructed their keys on the premise that the wettest types are identified first; perhaps they recognized the fact that $P$. tremuloides is more widespread than $P$. trichocarpa in giving it priority.

${ }^{1}$ Index value is a weighted measure of frequency and vitality, the $\%$ of plots in which species is flowering. 

What follows is a key to the moist to wet trembling aspen- and black cottonwooddominated communities of the BIR. Immediately following the key are the descriptions of the moist to wet site plant associations. The written descriptions attempt to characterize the environmental setting, overall composition and structure of the plant associations however, the composition of individual plots can be found in Appendix A, (stand table), the overall average composition for the plant association in Appendix B, (constancy-coverage table), and photographs of representative stands in Appendix J. These appendices employ six letter acronyms, the first three letters of the genus followed by the first three of the specific epithet, as shorthand for the scientific name.

Figure 3. KEY TO LIFEFORM GROUPS AND SELECTED DECIDUOUS FOREST TYPES OF THE BLACKFEET INDIAN RESERVATION

[Plant associations described in this document are in bold; their order of presentation in the text follows the order in which they occur in the key. Other wetland/riparian associations are found in Hansen et al 1995, or as noted]

1. Tree canopy cover, single species or combined cover, at least $25 \% \ldots \ldots \ldots \ldots 2$

1. Tree canopy cover, single species or combined cover, less than $25 \% \ldots \ldots \ldots \ldots$. $\ldots \ldots \ldots \ldots \ldots \ldots \ldots$ Non-forested types, not treated in this document

2. Coniferous trees present and reproducing successfully (10 or more trees per acre or canopy cover of seedlings/sapling $>5 \%$ ) . . . . . . Coniferous Forest Types (see Hansen et al. 1995 or Pfister et al. 1977)

2. Coniferous trees absent, or if present, then not reproducing successfully or restricted to microsites

3. Populus tremuloides (trembling aspen) present and reproducing successfully . . . 4

3. Populus tremuloides absent or, if present, not reproducing successfully ...... 8

4. Cornus stolonifera (red-osier dogwood) or wet site Salix spp. (willows, not including $S$. scouleriana) having at least $5 \%$ canopy cover, individually or in combination

Populus tremuloides/Cornus stolonifera plant association

4. Cornus stolonifera and wet site Salix spp., individually or in combination, having

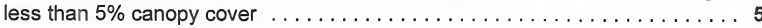

5. Calamagrostis canadensis (bluejoint reedgrass), C. stricta (narrow-spiked reedgrass), Alopecurus alpinus (alpine foxtail) or A. pratensis (meadow foxtail) either singly or their combined canopy cover at least $5 \%$ Populus tremuloides/Calamagrostis canadensis Plant Association 

5. Calamagrostis canadensis, C. stricta, Alopecurus alpinus, or A. pratensis either singly or their combined cover less than $5 \% \ldots \ldots \ldots \ldots \ldots \ldots \ldots \ldots$

Figure 3. Continued.

6. Osmorhiza occidentalis (western sweet-cicely), Angelica arguta (sharptooth angelica), Viola canadensis (Canada violet), Heracleum lanatum (cow-parsnip), Veratrum vinide (green false hellebore), Actaea rubra (baneberry), Galium triflorum (sweetscented bedstraw) individually, or in any combination, having at least $5 \%$ canopy cover

Populus tremuloides/Osmorhiza occidentalis Plant Association

6. Site lacking at $5 \%$ canopy cover, either singly or in any combination, of the following species, Osmoshiza occidentalis, Angelica arguta, Viola canadensis, Heracleum lanatum, Veratrum vinide, Actaea rubra, Galium triflorum ........... 7

7. Poa pratensis (Kentucky bluegrass), Phleum pratense (common timothy), or Agrostis stolonifera (redtop), their individual or combined canopy coverages at least $5 \% \ldots \ldots \ldots \ldots$. . . . . . . . . 7. Not as above ............ Populus tremuloides-dominated community types *

8. Populus trichocarpa (black cottonwood), $P$. angustifolia (narrowleaf cottonwood), or $P$. deltoides (Great Plains cottonwood) with a greater canopy cover than other individual tree species

8. Populus trichocarpa, $P$. angustifolia, and $P$. deltoides having less canopy cover than other individual tree species . (see Hansen et al. 1995 for further coverage)

9. Populus trichocarpa with greater canopy cover than either $P$. angustifolia or $P$. deltoides ........... Populus trichocarpa-dominated community types* 9. $P$. angustifolia or $P$. deltoides with greater canopy cover than $P$. trichocarpa ......

*Other $P$. tremuloides- and P. trichocarpa-dominated plant communities (e.g. P. tremuloides/ Symphoricarpos albus) do occur on the BIR and their description can be found in Hansen et al. 1995 or Cooper and Pfister 1981. 



\section{Populus tremuloides / Cornus stolonifera Plant Association \\ (POPTRE/CORSTO; trembling aspen/red osier dogwood; 3 plots; \\ WHTF ${ }^{1}$ designation POPTRE / Cornus sericea)}

Environment: This is the wettest of deciduous forest types we inventoried on the BIR and is the wettest vegetation type, when present, in local landscapes. It was seldom found in patches greater than an acre, though in its stringer form along steams and other water bodies its collective area is clearly greater. Small patches are also located in inter-morainal troughs. Very small fragments were found on mid-, lower-slope, and toe-slope positions; there was no obvious explanation for the high cover of $C$.

stolonifera at these positions except to invoke a subsurface source of water due to the complexity of water channeling in slump surfaces. Soils show strong gleying and mottling (except for the sideslope oddities). Adjacent communities were Salixdominated on wetter positions and Populus tremuloides / Calamagrostis canadensis or $P$. tremuloides / Osmorhiza occidentalis on drier, or at least slightly upslope positions.

Vegetation: It is important to note that our key to this community type differs, at least in defining species, from that described by Hansen et al. (1995). We recognize only Cornus stolonifera (FACW, see Appendix F) with at least $5 \%$ canopy cover as a significant indicator of wetland conditions, but two of the other shrub species (Prunus virginiana, Amelanchier alnifolia) listed in the key of Hansen et al. (1995) are not associated with wetlands, but rather uplands (Appendix $F$ ). For instance, accepting $A$. alnifolia as an indicator would broaden the concept of this type to include relatively dry upslope conditions. C. stolonifera cover varies widely and it appeared the higher coverages are associated with wetter conditions. More appropriate alternative indicators for this type are the various wetland Salix spp., e.g. S. boothii, S. bebbiana, S. geyeriana, which occur with coverages up to $10 \%$ and are definitely associated with wetland conditions.

The overstory is usually dominated by varying proportions of $P$. trichocarpa and $P$. tremuloides, but at least one stand was sampled, and others noted, having $P$.

tremuloides as the monospecific dominant. $P$. trichocarpa has a higher cover in POPTRE/CORSTO than in the other moist types, indicating that these sites are in fact wetter. [lt should be noted here that we have followed the lead of Hansen et al. (1995) in constructing our key so that $P$. tremuloides comes off before $P$. trichocarpa. But we feel this prioritization is inappropriate because of the two species, $P$. trichocarpa is more strongly associated with wetland conditions (see Appendix F) however, we have bowed to priority and followed Hansen's lead, not wanting to create competing classifications. Where drainages flow out onto the plains there are pure $P$. trichocarpa stands, however, these were not sampled, being beyond the parkland environment. For the mixed species stands there is no clear indication in size class structure of eventual

${ }^{1}$ Western Heritage Task Force of The Nature Conservancy 

domination by either species. In sampled stands Picea spp. and Abies lasiocarpa evidenced only very scattered seedlings and saplings, their cover not amounting to more than $5 \%$. However, during reconnaissance we noted several stands at the prairieforest juncture having at least $50 \%$ cover of coniferous species, predominantly Picea spp and low vigor Abies lasiocarpa, indicating that at least some of these sites may be climax in shade-tolerant conifers and constitute the Picea / Cornus stolonifera habitat type.

The graminoid component is invariably dominated by Elymus glaucous (blue wildrye) and Festuca subulata (bearded fescue) with Bromus ciliata (fringed brome), Alopecurus (foxtail) spp. and Calamagrostis canadensis (bluejoint reedgrass) occurring sporadically with high coverages (Appendix A). It should be noted that E. glaucous is the most ubiquitous graminoid of trembling aspen stands across the Intermountain West and Northern Rocky Mountains; often it has the highest cover of any graminoid present. Aggressive, weedy grasses apparently do very poorly here despite the fact that opportunities abound for animals, both domestic and natives, to introduce these species. There are a number of forbs with $100 \%$ constancy including Thalictrum occidentale, O. occidentalis, Viola canadensis, Sanicula marilandica, and Geranium richardsonii. A considerable variety of wetland herbs are present with varying constancy and cover; surprisingly Angelica arguta exhibited low constancy but very high coverage for those stands in which it occurred. The only forbs present associated with livestock use or disturbance are Prunella vulgaris and Urtica dioica.

Other Studies: As we have defined this plant association there are no other comparable regional types described. If one accepts $A$. alnifolia as an alternative indicator of the type as do Hansen et al. (1995), then there are vast extents of the Northern Rocky Mountains and Intermountain West dominated by various permutations of $P$. tremuloides / C. stolonifera (see Mueggler 1988). Of these combinations, the $P$. tremuloides / A. alnifolia/Tall Forb c.t. described by Mueggler (1988) is compositionally most similar to POPTRE/CORSTO, but it is far from being a wetland c.t. as described here. Both Bird (1961) and Moss (1955) indicate that Populus trichocarpa, Cornus stolonifera and Vibumum opulus are commonly associated with moist to wet aspen of southwestern Alberta but neither author provides plant association level descriptions. Almost certainly this plant association is present in southern Alberta, but given the intensive grazing pressure, seeding to introduced pasture grasses and habitat fragmentation associated with oil field development that has transpired in this region almost certainly stand condition has been negatively impacted.

Natural Heritage Program Rank: G3/S3 (Unchanged from Bourgeron \& Engelking 1994) 



\section{Populus tremuloides/Calamagrostis canadensis Plant Association (POPTRE/CALCAN; trembling aspen/bluejoint reedgrass; 11 plots)}

Environment: POPTRE/CALCAN is a minor type on the BIR and would appear to be associated with landscape positions as wet as those for POPTRE/CORSTO, but only infrequently were the two community types noted to occur in a mosaic pattern on the same landscape. Though Hansen et al. (1995) note both types to be well aerated, we speculate that the POPTRE /CALCAN p. a. is less so, occupying finer, more poorlydrained soils. The largest extents of the type were found bordering herbaceous- or Salix-dominated wetlands; other positions included inter-morainal troughs, alluvial benches and even toeslopes speculated to receive appreciable subsurface flow. Soils were predominantly loams, silt loams and silty clay loams, usually gleyed (or mottled) to within 15 to $20 \mathrm{~cm}$ of the surface.

Vegetation: The usual condition is a closed canopy overstory dominated by $P$. tremuloides, with $P$. trichocarpa being a considerable component on three fourths of the stands; in only two stands did $P$. trichocarpa exceed $P$. tremuloides in importance (canopy cover and basal area). Lynch (1955) also noted that $P$. trichocarpa was not present in all moist-site stands, observing that there was no apparent difference in site parameters and attributing the difference to local stochastisity in seed distribution at the time of establishment. In stands where both species are well represented there is no consistent indication one or the other gaining dominance. $P$. trichocarpa attains larger stem diameters but ultimate heights for both species asymptotically approach about 60 ft. P. trichocarpa also seems to be more infested with heart-rot fungal pathogens.

Shrubs are generally poorly represented in the undergrowth, with the exception of Symphoricarpos albus and Rosa woodsii, the average covers of which are 8 and $4 \%$, respectively. Shrubs with wetland indicator value include Salix boothii, S. bebbiana, $S$. geyeriana, Ribes americanum, $R$. setosum and Cornus stolonifera, but the coverages are low $(<5 \%)$ and constancy does not exceed $36 \%$ for any one of these species.

The predominant aspect of these stands is that of graminoid dominance with the wetland indicators Calamagrostis canadensis, C. stricta, Alopecurus alpinus and A. pratensis contributing more than half the cover and Elymus glaucous, Festuca subulata, and Phleum pratense contributing most of the rest. Other wetland graminoids sampled only in this type include Glyceria striata, Carex microptera, C. hoodii, C. brevior, and C. rostrata (syn. C. utriculata). This type differs from POPTRE/CORSTO by having disturbance increasers, Poa pratensis, Poa palustris, and Phleum pratense as a significant undergrowth component in some cattle-influenced stands. Some stands had an appreciable forb component with Angelica arguta, Arnica chamissonis, Epilobium ciliatum, Geum macrophyllum, Senecio foetidus, Aster laevis, Geranium richardsonii, Pedicularis bracteosa, Smilacina stelllata, Lathyrus ochroleucus, Galium boreale, G. triflorum and Fragaria virginiana having their highest constancy within this plant 

association; constancy for the listed species ranged from 36 to $100 \%$. The first five listed forbs are rated by US Fish and Wildlife Service as FACW' ${ }^{1}$ or wetter.

Other Studies: Other than the description in Hansen et al. (1995) the POPTRE/CALCAN plant association has not been described elsewhere within the region (Northern Rocky Mountains), but it has been described for both Colorado's Front Range (Mutel 1973) and the mountains of the state's south-central area (Powell 1988). Judged on a regional basis it appears to be an incidental type; even two of the six stands attributed by Hansen et al. (1995) to the type have 20\% cover of Alnus incana making the stands members of POPTRE/CORSTO, rather than POPTRE/CALCAN, in their taxonomy.

Natural Heritage Program Rank: G3/S3 (POPTRE?CALCAN is a relatively uncommon association but threats to it are minimal, at least to the Montana examples, even from overgrazing by ungulates. We have noted few weed problems with the exception of Urtica dioica. Poa pratensis can also form aggressive clones on these moist to wet sites. )

${ }^{1} \mathrm{FACW}$ is wetland indicator status designation assigned by US Fish \& Wildlife Service indicating a facultative wetland species that usually occurs in a wetland, i.e. with an estimated probability of $67-99 \%$, but is occasionally found in non-wetlands 



\section{Populus tremuloides/Osmorhiza occidentalis Plant Association}

(POPTRE/OSMOCC; trembling aspen/western sweet-cicely; 23 plots)

Environment: POPTRE/OSMOCC is the driest community type of the aspen parkland's mesic to hydric associations. It most usually grades to POPTRE/ Symphoricarpos albus of drier exposures and to POPTRE/CALCAN, POPTRE/ CORSTO, or Salix-dominated wetlands of moister sites. This plant association occupies a wider range of landscape positions and soils (or positions on soil catena) than either of the associations described previously. The driest positions occupied were sideslopes, from midslope to just below the shoulder break.; these sites are seldom found to have wetland soils. Ostensibly they do not possess wetland hydrology by virtue of their position, but the possibility of subirrigation is present in landscapes possessing slumps and clay lenses (such as the Kiowa area). The moistest positions were stream terraces where POPTRE/OSMOCC exists in complex mosaics with the two wetter trembling aspen types.

All the soils were silt loams or sandy loams and more than $80 \%$ of them had negligible rock in the upper 20 to $30 \mathrm{~cm}$ of the profile, where $80 \%$ of the root mass is concentrated. Several profiles were notably rocky to just below a 3-5 cm thick organic horizon, but these rocky substrates did not condition a distinct vegetation. As observed in the "Jurisdictional Wetlands" section these sites are overwhelming not jurisdictional wetlands, but the rank vegetation often gives an impression to the contrary.

One of the study's goals was to identify easily inventoried features such as wetland indicator plants (or their quantitative representation), perhaps in conjunction with landscape position, that would unequivocally identify wetland sites within this single broadly-defined plant association. Such a suite of species/landscape positions would provide for convenient inventory of wetland (jurisdictional) sites. Unfortunately no such suite of species or site features was identified.

Vegetation: The closed-canopy overstory is usually dominated by $P$. tremuloides with variable amounts of $P$. trichocarpa; in only five stands did $P$. trichocarpa have higher coverage than $P$. tremuloides, whereas in six stands it was completely lacking. Thus the constancy for $P$. trichocarpa is about the same in this association as the others, but its cover agerages at least $20 \%$ less. It is in this somewhat drier type that Picea is incrementally more successful, but still coverages did not exceed $13 \%$. In the course of tree coring we gained the impression more sound trees were found in this type than the others.

That this type is transitional to the distinctly upland type POPTRE/SYMALB is seen in the shrub composition where the cover or constancy, or both, is high for a number of upland shrubs, including Symphoricarpos albus, Rubus parviflorus, Rosa woodsii, Amelanchier alnifolia, and Salix scouleriana. A number of upland shrubs occur only in 
this of the three mesic to wet plant associations, including, but not confined to, Berberis repens, Juniperus communis, Potentilla fruticosa, Spiraea betulifolia, Sorbus scopulina, and Shepherdia canadensis.

This association is similar to POPTRE/CALCAN and POPTRE/CORSTO In composition by dominant graminoids (excepting wetland indicators), including Elymus glaucous, Bromus ciliatus and Festuca subulata. However, there are a number of upland graminoids recorded only for POPTRE/OSMOCC, including Calamagrostis rubescens, Stipa occidentalis, Melica subulata, Bromus pumpellianus and Dactylis glomerata. Species richness of the forb layer is high (73 species). Those species having their highest coverages or constancy in this type are Veratrum viride, Senecio pseudaureus, Actaea rubra, Aster engelmannii, Castilleja miniata, Disporum hookeri, Erythronium grandiflorum, Hackelia floribunda, Osmorhiza occidentalis, Smilacina racemosa, and Viola canadensis; only the first two named species are typical of wetlands (FACW or wetter, Appendix F). Two other wetland species, Angelica arguta ( $90 \%$ constancy, $5 \%$ c.c.) and Geum macrophyllum (72 \% constancy, $3 \%$ c.c.) are important across most of the stands of this type. As discussed In more detail in the "Jurisdictional Wetlands" section, despite the dominance of wetland vegetation as determined by the Corps of Engineers method, soils and hydrology more often than not fail to corroborate that these sites are in fact wetlands.

Other Studies: Lynch (1955) was the first to describe the POPTRE/OSMOCC plant association (as Populus spp./Osmorhiza occidentalis). Cooper and Pfister (1981) slightly augmented the description (calling the type POPTRE-POPTRI/OSMOCC) and provided an initial dichotomous key to forested plant associations, including deciduousdominated, on the BIR. Hansen et al. (1995) have devised a comprehensive classification for all of Montana's wetland types, of which POPTRE/OSMOCC was considered one; their description was based on 15 plots distributed across western Montana, but centered on the East Front of the Rocky Mountains.

In both site parameters and composition POPTRE/OSMOCC also bears a strong resemblance to the most commonly encountered trembling aspen type in the Intermountain Region, POPTRE/ Tall Forb (Mueggler 1988). Of the nine forb species Mueggler included in the Tall Forb Group (also referred to as guild or union) five (Aster engelmannii, Hackelia floribunda, Heracleum lanatum, Senecio serra, and Osmorhiza occidentalisa) also occur regularly in POPTRE/OSMOCC. Mueggler (1988) considers $10 \%$ canopy cover of any one of the Tall Forb Guild species or combination of these species to be sufficient for recognition of the community type. As in

POPTRE/OSMOCC the most important graminoid in POPTRE/Tall Forb is Elymus glaucous, followed by Bromus ciliatus and Poa pratensis. Mueggler speculated that many of the communities sampled in this tall forb type constitute a near-climax condition; in other words, the majority of these stands are self-perpetuating as those of the BIR are hypothesized to be. The Intermountain Region tall forb type differs from 

POPTRE/OSMOCC in lacking both POPTRI as a co-dominant and any wetland indicator species with a value of FACW or greater. These two types may simply represent regional expressions of a common type or at least define overlapping portions of the environmental gradient with POPTRE/OSMOCC, as defined, extending to wetter conditions on the soil moisture catena.

Natural Heritage Program Rank: G3/S3 (This is a common type within the trembling aspen parklands on the Blackfeet Indian Reservation and extending into the Canadian parklands [though possibly in a somewhat impacted condition with composition altered by the incursion of weedy and non-native species]. Continued threats to the association come from grazing (alteration of composition) and fragmentation through land development and oil exploration and development.) 



\section{Wetlands Determinations}

We were requested by several BIR resource staff members to make some general observations that might bear on the wetland status of BIR deciduous forests. It appeared that National Wetland Inventory (NWI) maps possibly overlooked their presence in the landscape. Determination of jurisdictional wetlands involves the evaluation of three parameters, soils, vegetation and hydrology; we applied the Corps of Engineers 1987 Manual (Environmental Laboratory 1987) methodology to determine wetland status.

Table 2 and Appendix $G$ (more detailed than Table 2) represent the data transcription of wetland species from raw data forms to synopsis form, treating wetland vegetation by the categories obligate, facultative wet and merely facultative (see Appendix $F$ for full species name, common and scientific, and an explanation of wetland indicator categories), whether soils are hydric or not, and whether or not hydrology is indicative of wetland functions. It should be appreciated that a one-time site visit, especially at the end of summer, is usually insufficient to effectively evaluate some parameters, particularly hydrological ones. Whether the hydrology is that of a wetland is often arrived at through circular reasoning or surrogate variables and not by direct observation of hydrological conditions at the site at a critical time in the cycle. Of the 37 stands inventoried $46 \%$ met wetland criteria, though some were borderline cases generally due to uncertainties about either soils or hydrology; some borderline cases were encountered when the wetland vegetation indicators present just met the $50 \%$ cutoff mark.

There are some clear trends present in percentages of wetlands present when sites are stratified by vegetation type. Sites typified as POPTRE/CORSTO possessed unequivocal indications of wetland soils, with mottling and gleying always present. The wetland vegetative indicators averaged $68 \%$ (range 60 to $72 \%$ ) of the dominant species, of which on average $26 \%$ (range 14-43\%) were FACW class or greater. The landscape settings were primarily adjacent to stream courses and could be inferred to meet hydrological criteria with overbank flow (evidence in wrack lines and silt deposits) and saturated soils for a prolonged period during spring runoff.

Within the POPTRE/CALCAN plant association $27 \%$ of the sites are unequivocal wetlands, $64 \%$ equivocal wetands (91\% wetlands of some status) and $9 \%$ nonwetlands. Of the dominant species, wetland indicators comprise from 36 to $100 \%$ and average $68 \%$; the percentage of species FACW or greater ranges from 18 to 57 and averages 42 . Only two stands (18\%) within this grouping did not meet the vegetation criteria of more than $50 \%$ of the dominants being wetland species; one of these sites was clearly not wetland but the other lacked only the vegetation criteria, though in terms of indicator species (and not their cover weighted \%) a wetland condition clearly 

Table 2. Wetland determination results; matrix of sample plots by Jurisdictional Wetland parameters and community type Vegetation (\% by Class)

Hydrophytic Hydric WetlandJurisdictional

Total Percent Vegetation Soils HydrologyWetland

Plot Number Community Type OBL FACW FAC/FAC+ Wetland Species Y, N, ?

\begin{tabular}{|c|c|c|c|c|c|c|c|c|c|}
\hline & & & & & & & & & \\
\hline $96 \mathrm{SC} 0017^{*}$ & POPTRE/CORSTO & 0 & 20 & 40 & 60 & $\mathrm{Y}$ & $\mathrm{Y}$ & $\mathrm{Y}$ & Y: no question \\
\hline $96 \mathrm{SC} 0018$ & POPTRE/OSMOCC & 0 & 12 & 50 & 62 & $\mathrm{Y}$ & $?$ & $\mathrm{Y}$ & Y: \\
\hline $96 \mathrm{SC} 0019$ & POPTRE/CORSTO & 0 & 14 & 57 & 71 & $\mathrm{Y}$ & $\mathrm{Y}$ & $\mathrm{Y}$ & Y: unequivocal \\
\hline $96 \mathrm{SC} 0020$ & POPTRE/OSMOCC & 0 & 14 & 57 & 71 & $\mathrm{Y}$ & $\mathrm{N}$ & $\mathrm{N}$ & $\mathrm{N}:$ \\
\hline $96 \mathrm{SC} 0021$ & POPTRE/CALCAN & 0 & 50 & 20 & 70 & $\mathrm{Y}$ & $\mathrm{Y}$ & $\mathrm{Y}$ & Y: unequivocal \\
\hline $96 \mathrm{SC} 0022$ & POPTRE/CORSTO & 0 & 43 & 29 & 72 & $\mathrm{Y}$ & $\mathrm{Y}$ & $\mathrm{Y}$ & Y: unequivocal \\
\hline $96 \mathrm{SC} 0023$ & POPTRU/CALCAN & 0 & 50 & 20 & 70 & $\mathrm{Y}$ & $\mathrm{Y}$ & $\mathrm{Y}$ & Y: unequivocal \\
\hline $96 \mathrm{SC} 0024$ & POPTRE/CALCAN & 0 & 36 & 27 & 63 & $\mathrm{Y}$ & $\mathrm{Y}$ & $\mathrm{Y} ?$ & Y: questionable \\
\hline $96 \mathrm{SC} 0025$ & POPTRE/CALCAN & 0 & 29 & 36 & 72 & $\mathrm{Y}$ & $\mathrm{Y}$ ? & $\mathrm{Y} ?$ & Y: questionable \\
\hline $96 \mathrm{SC} 0026$ & POPTRE/OSMOCC & 0 & 25 & 50 & 75 & $\mathrm{Y}$ & $\mathrm{N}$ & $\mathrm{N}$ & $\mathrm{N}:$ \\
\hline $96 \mathrm{SC} 0027$ & POPTRE/OSMOCC & 10 & 20 & 40 & 70 & $\mathrm{Y}$ & $\mathrm{Y}$ & $\mathrm{Y}$ & Y: unequivocal \\
\hline $96 \mathrm{SC} 0028$ & POPTRE/OSMOCC & 0 & 0 & 50 & 50 & $\mathrm{Y} / \mathrm{N}$ & $\mathrm{N}$ & $\mathrm{N}$ & $\mathrm{N}:$ \\
\hline $96 \mathrm{SC} 0029$ & POPTRE/OSMOCC & 0 & 0 & 57 & 57 & $\mathrm{Y} / \mathrm{N}$ & $\mathrm{N}$ & $\mathrm{N}$ & $\mathrm{N}:$ \\
\hline $96 \mathrm{SC} 0030$ & POPTRE/OSMOCC & 0 & 11 & 33 & 44 & $\mathrm{~N}$ & $\mathrm{~N}$ & $\mathrm{~N}$ & $\mathrm{~N}:$ \\
\hline $96 \mathrm{SC} 0031$ & POPTRE/OSMOCC & 0 & 28 & 28 & 57 & $\mathrm{Y}$ & $\mathrm{Y}$ & Y? & Y: (equivocal) \\
\hline $96 \mathrm{SC} 0032$ & POPTRE/OSMOCC & 0 & 20 & 50 & 70 & $\mathrm{Y}$ & $\mathrm{N}$ & $\mathrm{N}$ & $\mathrm{N}:$ \\
\hline $96 \mathrm{SC} 0033$ & POPTRE/OSMOCC & 0 & 25 & 37 & 62 & $\mathrm{Y}$ & $\mathrm{N}$ & $\mathrm{N}$ & $\mathrm{N}:$ \\
\hline $96 \mathrm{SC} 0034$ & POPTRE/OSMOCC & 0 & 12 & 25 & 37 & $\mathrm{~N}$ & $\mathrm{~N}$ & $\mathrm{~N}$ & $\mathrm{~N}:$ \\
\hline
\end{tabular}

* Numbering of BIR aspen-black cottonwood plots began at 0017 and extended through 0053 

Table 2(Continued). Matrix of sample plots by Jurisdictional Wetland parameters and community type Vegetation (\% by Class)

Hydrophytic Hydric WetlandJurisdictional

Total Percent Vegetation Soils HydrologyWetland

Plot Number Community Type OBL FACW FAC/FAC+ Wetland Species Y, N, ?

$\mathrm{Y}, \mathrm{N}$, ? $\quad \mathrm{Y}, \mathrm{N}$, ? $\quad \mathrm{Y}, \mathrm{N}$, ?: why

\begin{tabular}{|c|c|c|c|c|c|c|c|c|c|}
\hline $96 \mathrm{SC} 0035$ & POPTRE/OSMOCC & 0 & 0 & 40 & 40 & $\mathrm{~N}$ & $\mathrm{~N}$ & $\mathrm{~N}$ & $\mathrm{~N}:$ \\
\hline $96 \mathrm{SC} 0036$ & POPTRE/CALCAN & 0 & 33 & 33 & 67 & $\mathrm{Y}$ & $?$ & Y & Y: equivocal \\
\hline $96 \mathrm{SC} 0037$ & POPTRE/OSMOCC & 0 & 12 & 50 & 62 & $\mathrm{Y}$ & $\mathrm{Y}$ & $\mathrm{Y} ?$ & Y: equivocal \\
\hline $96 \mathrm{SC} 0038$ & POPTRE/OSMOCC & 0 & 0 & 60 & 60 & $\mathrm{Y}$ & $\mathrm{N}$ & $\mathrm{N}$ & $\mathrm{N}:$ \\
\hline $96 \mathrm{SC} 0039$ & POPTRE/CALCAN & 0 & 57 & 29 & 86 & $\mathrm{Y}$ & $?$ & $\mathrm{Y}$ & Y: equivocal \\
\hline $96 \mathrm{SC} 0040$ & POPTRE/OSMOCC & 0 & 0 & 42 & 42 & $\mathrm{~N}$ & $\mathrm{~N}$ & $\mathrm{~N}$ & $\mathrm{~N}:$ \\
\hline $96 \mathrm{SC} 0041$ & POPTRE/OSMOCC & 0 & 12 & 37 & 50 & $\mathrm{Y} / \mathrm{N}$ & $\mathrm{N}$ & $\mathrm{N}$ & $\mathrm{N}:$ \\
\hline $96 \mathrm{SC} 0042$ & POPTRE/CALCAN & 0 & 50 & 50 & 100 & $\mathrm{Y}$ & $\mathrm{Y}$ & $\mathrm{Y}$ & Y: unequivocal \\
\hline $96 \mathrm{SC} 0043$ & POPTRE/OSMOCC & 0 & 14 & 43 & 57 & $\mathrm{Y}$ & $\mathrm{Y}$ & $\mathrm{N}$ & $\mathrm{N}$ : borderline \\
\hline $96 \mathrm{SC} 0044$ & POPTRE/OSMOCC & 0 & 12 & 25 & 37 & $\mathrm{~N}$ & $\mathrm{Y} ?$ & $\mathrm{Y} ?$ & $\mathrm{~N}:$ \\
\hline $96 \mathrm{SC} 0045$ & POPTRE/OSMOCC & 0 & 33 & 11 & 44 & $\mathrm{~N}$ & $Y ?$ & $\mathrm{Y} ?$ & $\mathrm{~N}:$ \\
\hline $96 \mathrm{SC} 0046$ & POPTRE/CALCAN & 0 & 36 & 9 & 45 & $\mathrm{~N}$ & $\mathrm{Y} ?$ & $\mathrm{Y}$ & Y: equivocal \\
\hline $96 \mathrm{SC} 0047$ & POPTRE/OSMOCC & 0 & 20 & 20 & 40 & $\mathrm{~N}$ & $\mathrm{~N}$ & $\mathrm{~N}$ & $\mathrm{~N}:$ \\
\hline $96 \mathrm{SC} 0048$ & POPTRE/CALCAN & 0 & 57 & 29 & 86 & $\mathrm{Y}$ & $\mathrm{Y}$ & $\mathrm{Y}$ & Y: \\
\hline $96 \mathrm{SC} 0049$ & POPTRE/OSMOCC & 0 & 12 & 50 & 62 & $\mathrm{Y}$ & $\mathrm{N}$ & $\mathrm{N}$ & $\mathrm{N}:$ \\
\hline $96 \mathrm{SC} 0050$ & POPTRE/OSMOCC & 0 & 20 & 40 & 60 & $\mathrm{Y}$ & $\mathrm{Y}$ & $\mathrm{Y}$ & Y; \\
\hline $96 \mathrm{SC} 005 \mathrm{I}$ & POPTRE/CALCAN & 0 & 42 & 8 & 50 & $\mathrm{Y} / \mathrm{N}$ & $\mathrm{Y}$ & $?$ & Y: equivocal \\
\hline $96 \mathrm{SC} 0052$ & POPTRE/CALCAN & 0 & 18 & 18 & 36 & $\mathrm{~N}$ & $\mathrm{~N}$ & $\mathrm{~N}$ & $\mathrm{~N}:$ \\
\hline $96 \mathrm{SC} 0053$ & POPTRE/OSMOCC & 0 & 0 & 50 & 50 & $\mathrm{~N}$ & $\mathrm{~N}$ & $\mathrm{~N}$ & $\mathrm{~N}:$ \\
\hline
\end{tabular}


obtained. This association represents the strongest expression of wetland plant species, though a small percentage of sites were in fact not jurisdictional wetlands. Some of these sites possessed soils with stronger gleying and mottling and with these conditions occurring closer to the soil surface than was expressed in the POPTRE/CORSTO association. It is quite possible that POPTRE/CALCAN spans, in terms of duration of soil saturation (and associated anoxic conditions), a broader environmental range than does the POPTRE/CORSTO association; clearly this type is found in a greater variety of landscape positions than is POPTRE/CORSTO, ranging from streamside stringers of alluvial terraces to subirrigated toeslopes to glacial depressions.

POPTRE/OSMOCC is cited as a major wetland vegetation type by Hanson et al. (1995), but our sampling of this type indicates that only $22 \%$ of the sites were wetlands, some equivocally so; only 3 sites ( $13 \%$ ) were unequivocal wetlands. If vegetation (wetland indicator species) alone is the criterion, then $65 \%$ of the sites qualify as wetlands. This vegetation type had the lowest percentage of wetland indicator species, averaging $55 \%$ of dominant species and ranging from 36 to $75 \%$. It also had, by far, the lowest average percent composition (13\%) of indicators that were at least FACW and 5 sites had no FACW species at all. This vegetation type occupies the widest range of environments, from hill sideslopes to toeslopes to alluvial bottoms. The hillslope positions obviously are not expected candidates for possessing wetland hydrology, unless subirrigation could be inferred from the presence of restrictive layers (e.g. clay lenses) causing near-surface flow. Only one hillslope site had evidence (mottling) of seasonally high water and no obvious soil feature (in a $1.1 \mathrm{~m}$ deep soil pit) could account for water perching at this position.

Implications of this inventory's results regarding NWI mapping and the extent of jurisdictional wetlands on BIR lands are several. In a quick scan of NWI maps we noted that none of the first 12 sites we had sampled and identified as wetlands were included as palustrine forested wetlands in the NWI mapping. We suggest that, based on community type present and landscape position alone, wetlands maps could be corrected to reflect the much greater contribution of forested wetlands on the BIR; this approach would obviate the excavation of soil pits and hypothesizing about hydrologic regime. It is with a relatively high degree of certainty ( $85 \%$ plus) that the presence of POPTRE/CORSTO and POPTRE/CALCAN associations indicate wetlands and polygons in which these plant communities occur can be so labeled. The POPTRE/OSMOCC association presents no unequivocal answer that a wetland is present but at least it indicates areas where soil pits should be excavated and the hydrologic regime investigated. 



\section{Stand Structure and Successional Status}

Figure 4 shows the results of tree coring to establish the age of stand dominants. Populus tremuloides and $P$. trichocarpa were not distinguished on this plot due to strong similarities in their height and diameter growth patterns (Moss 1932) and the fact that only two $P$ trichocarpa were successfully bored and counted (with great difficulty). About three quarters of the stands were successfully cored for at least one tree age. To the extent that coring attempted on 5 to 7 dominant trees resulted in failure to extract a readable core, then approximately one quarter of the stands had significant heart rot or other wood defects. Even coring at breast height, as Lynch (1955) cited doing to avoid basal heart rot, was not successful. Coring of $P$. trichocarpa usually resulted in being squirted with a stream of watery fluid in which were borne the core fragments when the extractor was withdrawn.

Populus tremuloides under current climatic conditions in the Intermountain West is known to reproduce via adventitious shoots from roots (sucker shoots) only (exceptions to this reproductive mode are so unusual as to be documented in notes to various botanical journals). Conventional wisdom holds that aspen groves throughout this region have been in place for possibly thousands of years, establishing sometime in late Pleistocene times, or sometime thereafter, when pluvial climates were still in force.

Thus ages from trees of the largest size class may represent time since last disturbance or they may simply represent the oldest tree still standing (see discussion of reverse Jshaped curve of size class structure); they do not represent time since stand establishment.

Populus trichocarpa also is also known as a colonizer of disturbed surfaces, usually associated with riparian environments, preferentially establishing as seedlings on fresh alluvium, on point bars or other recently deposited surfaces. Though this species is most commonly found on the BIR in riparian environments, it has a notable presence in the aspen parkland and this is a distinctly uncommon habitat for its occurrence, a pattern generally not found elsewhere in its distribution. It is also capable of reproducing via root sprouting within established stands, though not so prolifically as $P$. tremuloides.

Figure 4 indicates that tree height is moderately correlated with diameter breast height. Tree height, for both $P$. tremuloides and $P$. trichocarpa, even for the largest diameter size classes in the 18 to 24 inch range never exceeded 60 feet. Size classes greater than 18 inches are not shown on Figure 4 because readable cores could never be extracted from specimens this large, almost invariably $P$. trichocarpa. In Lynch's study (1955) of BIR parklands for the $P$. tremuloides/ Osmorhiza occidentalis plant association the average height of $P$. trichocarpa was 56 feet and $P$. tremuloides 45 feet. From Figure 4 it can be inferred, at least for $P$. tremuloides, that there has been little height growth on a per stand basis in the intervening 45 years between Lynch's study and ours. In fact, average stand height may have decreased due to wind damage. West of Glacier National Park at the same latitude and elevation as the BIR parklands aspen of 

Figure 4. Plots of near maximum tree age and height (feet) versus tree diameter at breast height.

Plots of Tree Height and Age versus Dlameter Breast Height

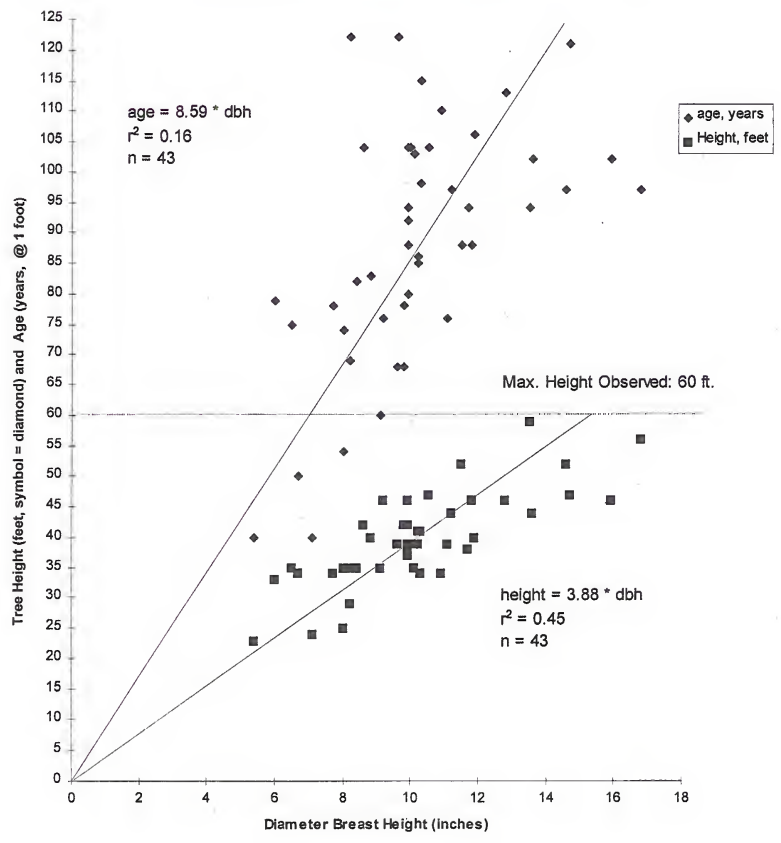



70 to 80 feet tall are common. We cite wind as the primary factor influencing tree height because further north (central Alberta) Moss (1932) found on the better sites dominant trees at only 50 years (index age) to be 50 to 60 feet tall, heights never attained at this age by BIR aspen (or black cottonwood). Though Chinook winds blow along the whole of the eastern front of the Rocky Mountain the greatest frequency and strength is registered from Browning to just north of Lethbridge, Alberta (Yoshino 1975); the dessicating and trimming effects of these winds may account for the relatively short stature of BIR aspen stands.

Lynch (1955) cited the mean dbh for dominants of the $P$. tremuloides/Osmorhiza occidentalis plant association to be 7.7 and 12.8 inches for $P$. tremuloides and $P$. trichocarpa respectively. From the $P$. tremuloides histogram (Figure $5 a$ ) it is clear that this species has matured considerably and of the three stands with the largest size class represented of 7 inches or less, two have $P$. tremuloides as the tree species growing into a $P$. trichocarpa-dominated stand. This leaves but one $P$. tremuloidesdominated stand wherein its largest size class is the same or smaller than the average size dominant reported by Lynch (1955). In the intervening 45 years from Lynch's study to ours it is well within the bounds of extrapolation to project these dominant trees putting on from 2 to 8 inches of diameter growth. From this pattern we can infer there has been little stand structure disturbance overall in the parkland since Lynch's 1952 study (reported in 1955), assuming that neither Lynch nor ourselves have biased sampling by selecting stands with regard to stem size criteria and that both our samples reflect the parkland structure as it then and now exists.

Lynch's average age of dominant $P$. tremuloides in the POPTRE/Osmorhiza occidentalis plant association was 78 years in 1952 ; it is tempting to extrapolate and say that the average age of today's dominants should be 122, plus or minus a few years, but such extrapolation is not justified. It is this oldest/largest class of trees that yielded few readable cores due to heart rot and other maladies and that would have experienced the greatest mortality in the intervening years. We often had to core smaller and ostensibly younger trees to obtain a countable core, hoping it would at least give us a minimum age since disturbance or stand "age". Moss (1932) states that "rarely" do $P$. trichocarpa and $P$. tremuloides exceed 135 and 120 years, respectively; these ages come from trees growing in more favorable environments (inferred from greater tree heights).

The histogram (Figure $5 \mathrm{~b}$ ) showing largest size classes of $P$. trichocarpa present in a stand is bimodal and indicates through the presence of several small size classes that there are some stands with ingrowth of this species into $P$. tremuloides-dominated stands. Lynch (1955) gives no indication of the distribution of maximum dbh size classes, only the average of 12.8 inches; we must infer that the stands with $15,17,21$, and 23 inch classes present represent those with the expected subsequent diameter increase since Lynch's (1955) study. 

Figure 5. Frequency distributions by species for the largest size class represented within each stand, a) for Populus tremuloides, b) for Populus trichocarpa.

Frequency distribution; largest Populus tremuloides size class represented for each stand

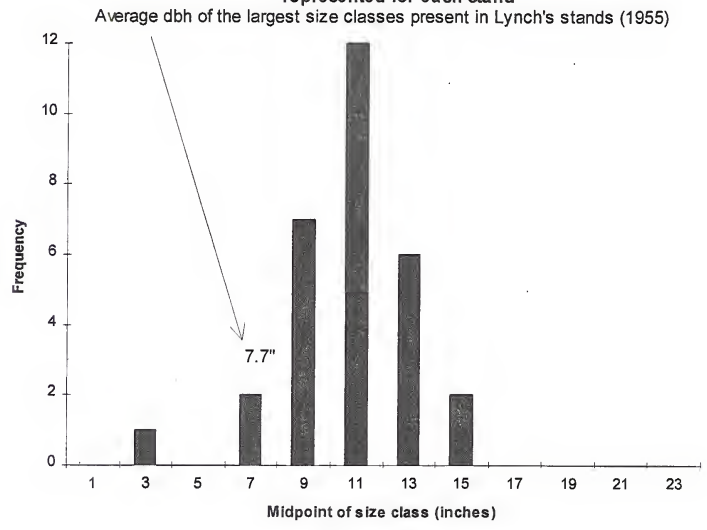

Frequency distribution; largest Populus trichocarpa size class represented for each stand

Average dbh of the largest size classes present in Lynch's stands (1955)

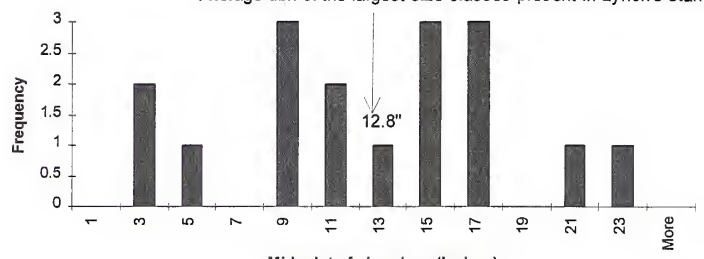

Midpoint of size class (inches) 

Appendices $\mathrm{C}, \mathrm{D}$, and $\mathrm{E}$ display the results of the tree species population inventory (tallied by 1 inch size classes In the field) converted to 2 inch classes for ease of presentation and interpretation. The scatterplots (Appendix $\mathrm{C}$ ) of stem/acre against $\mathrm{dbh}$ size classes ( 2 inch increments) are most easily examined for repeating patterns of reproduction and stand structure; Appendices $D$ and $E$ simply present the same data as Appendix $C$, but with more detail such as stem number or basal area by species and diameter class.

The most common pattern of size class structure, a negative exponential, or, as referred to colloquially in the literature reverse J-shaped curve (Oliver \& Larson 1992), is exemplified by stands $24,28,30,35,36,39,50$ and others (Appendix C), though not with so classical a curve form. Within this group of stands are represented all three plant associations and the full range of the wetland gradient. For this set of stands stem numbers per acre are high in the smaller diameter classes and decline precipitously with increasing size classes. Note that the smallest size class spans a range of only 1 inch (breast height diameters $>1$ and $<2$ inches) and therefore potentially encompasses many fewer stems than the size classes spanning 2 inches. The narrow span of this class centered on 1.5 inch midpoint accounts for several of the graphs not peaking in the smallest size class as would be expected for this type of distribution. It is these stands with the reversed J-shape frequency-by-size-class structure that often have the largest size classes represented, but with very few stems per acre.

Of all the stands sampled these most closely approximate what may be termed "old growth" or "mature" structure, though stem ages did not exceed 122 years (certainly not old when compared to age potentials of conifers native to BIR lands). This size class structure pattern is also known as "stable" because of an somewhat constant recruitment of stems into the smallest (youngest) classes and a consistent rate of mortality by class. This structure is that expected from self-replacing stands; it is the structure exhibited by mixed-species or monospecific dominant old-growth stands of shade-tolerant conifers. However, the case with Populus tremuloides and $P$. trichocarpa is quite different from that of climax conifers because both species are notably shade-intolerant and short lived. Virtually all the stems (the individual trees, known technically as ramets) originating in an aspen stand represent the production of one genetic entity and constitute a clone. Black cottonwood is not as strongly clonal in nature. As mortality claims the older (larger) stems in a stand apical dominance is weakened and the root systems send up suckers; in general, the greater the motality and lessening of apical dominance, the greater the suckering response.

The other textbook structural pattern evident in our data is the even-sized (even-aged) development exemplified by stands 17, 20,29,33, 34, 40, 50 and others (Appendix C). All three plant associations and the full spectrum of wetland conditions are represented in this group of stands. Stem density peaks in one or two size classes; increment coring shows that stems from these highest density size classes (or even three classes) are essentially even-aged, being within 1-12 years of one another; stand ages of the abovecited six stands were respectively, 62, 122, 69, 42, 54, and 96 (no age stand 20) based 

on the largest size class with near peak population size. With the exception of stands 29 and 51 (122 and 106 yrs.) these are among the youngest stands In our sample. Mortality has not yet begun to thin out the older age classes (see Appendix A, dead stem density); most mortality is in younger suppressed size classes, which are themselves not very densely populated due to apical dominance of the mature stems. Comparing the oldest stands, 29 (122 yrs) and 51 (106 yrs.), that still exhibit the pulse of post-disturbance reproduction it appears that the greater stem density of stand 29 is responsible for the continued suppression of root sprouting. In contrast stand 51 shows low density in the large classes (half that of stand 29) and moderate mortality across all size classes that possibly accounts for the spurt in suckering.

This successional development in aspen is analogous to classic cases, such as post burn succession with lodgepole pine giving rise to even-aged, sometimes "doghair" dense, stands. The only troubling aspect to the aspen scenario on the BIR is the general lack of evidence for fire, both in the soil (charcoal) and above ground (stumps and downed boles). We speculate that in these moist environments decay of these nutrient-rich softwoods is accelerated relative to what would be expected with conifers, leaving little or no evidence after 50 or more years since the disturbance. Another possibility is that certain of these stands were harvested for firewood; leaving no evidence in the soil or above ground (save for stumps which decay quickly due to their continued connection to the moist soil column).

There are other patterns exhibited in the size class data, such as rather flat curves where numbers drop only slowly with increasing size (age) classes, exemplified by stands $26,37,42$, and 43 among others. Other stands, such as 19 , show spikes in particular size classes for no obvious reasons. One can speculate that some past event may have weakened apical dominance, for example several consecutive years infestation by the western tent caterpillar (Malacosoma californicum), allowing a cohort of suckers to become established. Sampling error is another possibility for injecting spikes and valleys in the data; $1 / 10$ acre plots are perhaps undersized for sampling population structure when stem numbers are low or when formerly relatively homogeneous stands begin to fragment with patches of mortality.

An occasional cone bearing Engelmann spruce (Picea engelmannii) or hybrid with white spruce ( $P$. glauca) was found in these stands but, despite the considerable seed rain, spruce seedling density was generally in the range of only $1-50$ per acre. The per stand basal area contribution of spruce was much less than 1 percent. The establishment of Abies lasiocarpa (subalpine fir) and Pseudotsuga menziesii (Douglas-fir) is occurring at even slower rates than for spruce. At these rates of establishment it would take many hundreds to thousands of years without disturbance for succession to result in spruce or mixed conifer stands.

Most of these moist to wet aspen- and black cottonwood-dominated stands should be viewed as self-replacing. In the wetter of the three plant associations, POPTR/CORSTO and POPTRE/CALCAN, P. trichocarpa has higher canopy cover in 

the stands in which it is present than it does in the drier POPTRE/OSMOCC plant association. Of the stands wherein both species are present in the seedling to sapling size classes (up to 5 inches dbh) $22 \%$ of the stands show $P$. trichocarpa to have higher stem counts, indicating it could possibly be the canopy dominant at a future date. However, scanning the mortality plots (Appendix $C$ ) it is obvious that mortality can take out whole size classes, rendering moot speculations about eventual dominance in these mixed species stands. For almost $90 \%$ of the stands sampled $P$. tremuloides appears to be the species most successfully replacing itself, regardless of plant association involved.

It should be added parenthetically that in the course of conducting 1997 field investigations relating to grassland ecology that we encountered several mature, moist to wet, aspen-dominated stands on the eastern fringe of the aspen parkland sites wherein Picea and Abies lasiocarpa were clearly establishing successfully and population structure indicated their eventual site dominance. Thus it appears that with or without periodic disturbance, aspen and non-riparian black cottonwood groves will continue to flourish, but that certain of these trembling aspen-black cottonwood groves will succeed to conifer dominance. At this time we have not identified those predictors that would distinguish climax aspen habitats from those successional to conifers.

One of the more puzzling aspects of the aspen parkland, at least concerning mesic sites, is why rock content is so uniformly low ( $<5 \%)$, often completely lacking, in the upper portions (upper $20-30 \mathrm{~cm}$ ) of soil profiles. For mesic sites, virtually all parkland soils (which we textured only by feel) were silt loams to loams, at least in the upper 30 $\mathrm{cm}$ of the profile. Some of these rock-free soils may be attributed to resorted glacial deposits which have been deposited along old glacial drainage courses or in lakes or depressions near the retreating ice. However, many of the upslope soils are virtually rock-free as well. We hypothesize that the lack of rock in these profiles (rock is present in conifer-dominated stands and drier aspen stands) is attributable to the upper profile being composed largely of aeolian materials, including volcanic ash. Both Mt. Mazama and Glacier Peak volcanic events are post-Pleistocene and could have contributed ash. Another, much greater source of aeolian material is the glacial drift surfaces that would have been newly created the north and west. In the pluvial climates of post-Pleistocene (post-Glacial) times aspen and black cottonwood, with their cottony, wind disseminated seeds that require prolonged moisture, could have been among the early colonizers of freshly created substrates. These groves would likely have been the tallest and densest vegetation in the landscape; their canopies would have served to create eddy currents and resulted in airborne particles coming out of suspension. The Canadian literature also contains speculations that these sites were first stabilized by grasslands and evolved to aspen forest. 



\section{Disease, Defect, Pests}

Preliminary data on forest disease and defect was collected following the guide of Hiratsuka et al. (1995) and descriptions of Hinds (1985). No trees were sectioned or their bases excavated to make more definitive identification of agents responsible for heart rots, cankers or insect damage. In the narrative that follows we describe various fungal and bacterial conditions as though they occurred one to a tree but in reality there is generally a complex of infestations associated with a tree; in many cases these infestations have been shown to follow a somewhat predictable successional sequence (Hinds 1985).

Though not explicitly tallied, it is safe to say virtually all cored trees showed some degree of discoloration and softening of interior wood, which can be interpreted as resulting from some form of fungal (or possibly bacterial) infestation. Only two specimens of $P$. trichocarpa were successfully cored and even these had some punky wood. By far the most common bole defect encountered in $P$. trichocarpa we would describe as "wetwood" analogous to this condition as described for $P$. tremuloides (Hinds 1985); this malady was noted very infrequently in $P$. tremuloides cores. Wetwood is caused primarily by invasion of sapwood by bacteria, presumably from initial root infections. In specimens we cored, copious bleeding of a watery sap followed core extraction; we presume that water pools in lumina created from the mass destruction of xylem cells. Other disease symptoms associated with wetwood include branch dieback, crown wilting and premature death.

Phellinus tremulae, the predominant trunk rot or white heart rot fungus of Populus spp. in North America, is probably the easiest of the wood decay agents to identify with its distinctive $7-20 \mathrm{~cm}$ wide conk having a purplish-brown undersurface. If its presence is accounted for only by conks, then this pathogen occurred in about $32 \%$ of the stands, usually on larger ( $\left.>9^{\prime \prime} \mathrm{dbh}\right) P$. tremuloides and infested from 10 to $100 \%$ of this species within a given stand. Because sporophores form on only a small fraction of the trees infected (Lynch 1955) it is difficult to gauge the incidence of infestation. In Ontario, 28 to $70 \%$ of the trees in 60 to 70 years old stands were infected (Hinds 1985). Its presence renders age coring virtually impossible as the decay column continues for most of the main stem's length; usually the wood is so soft it cannot even be used for pulping. Conks of the $P$. tremulae type were not noted on $P$. trichocarpa.

Only one instance of Armillaria "root rot" was found as indicated by honey colored mushrooms and rhizomorphs in the soil and rotted wood at the base of the tree. The mushrooms are produced only in late summer and early fall; the black stringy rhizomorphs (black-string root rot) are always present but for proper identification require excavation in the vicinity of the tree base; basal excavation was beyond the scope of our work and thus this pathogen could have had a much greater presence than we recorded. This pathogen produces rot in roots and tree butts and could explain part of the lack of success in basal tree coring. 

Trunk canker is the most obvious disease problem of aspen in the West (Hinds 1985). We noted trunk canker symptoms (lesions, formation of callus tissue, dead bark sloughing, often in long stringy strips, blackened and sooty bark, concentric stem girdling) on many dead and dying $P$. tremuloides and $P$. trichocarpa trees of all size classes, but particularly on smaller to mid-size dbh classes. We made no attempt to identify the fungal species causing these symptoms. This broad group of fungal diseases is cited as the major cause of aspen mortality but we had no way of knowing which among the wide range of fungal diseases present in the sampled stands, including heart rots, root rots, was actually responsible for the deaths of individual trees.

The canopy of one stand was noted to be producing an extremely fine exudate dispersed into the air and deposited on the undergrowth and aspen seedlings. Neither the exact source or causative agent of the aerosol, nor consequences to the stand could be determined.

At the time of sampling none of the sampled stands were infested by western tent caterpillar (Malacosoma califomicum) and this insect pest was not noted in general reconnaissance. Severe outbreaks have been noted on the BIR with multiple year defoliation, but it is our impression these infestations have not resulted in wholesale mortality. 



\section{Animal Impacts}

At grove margins some stems has been gnawed by either porcupine (Erethizon epixanthum) or snowshoe rabbits (Lepus americanus). The aspen groves of the BIR are obviously not under native ungulate pressure, most especially not from elk (Cervus canadensis), of the type that has resulted in the wholesale loss of aspen stands in western Wyoming and Yellowstone National Park (Krebill 1972, Kay and Wagner 1994). Even with the extensive Yellowstone fires of 1988 aspen stands have not been able to establish suckers greater than 2 meter in height and are still a target for browsing elk. The situation appears to be quite different on the BIR with the only positive evidence of animal induced mortality to aspen being from beaver (Castor canadensis) gnawing and felling trees.

The abrasion of antler felt was the elk (Cervus canadensis) damage most frequently observed. This activity left almost all trees of particular stands with wounds to trunks and branches. We also observed wounding to the main stem from gnawing and in several cases mortality resulted from stem girdling. With the exception of girdling, this wounding apparently does not immediately result in loss of stand vigor or health. However, wounding of any kind, from any source, that breaches the bark potentially constitutes an entry point for disease vectors, most especially a whole host of pathogenic fungi. Stands with elk damage had no obviously greater incidence of heart rot or cankers.

It would appear that the very scattered seedlings of Abies lasiocarpa (subalpine fir) present in these aspen stands are browsed (portion above snowpack) by some agent, most likely moose (Alces alces). The consequence for aspen stands is that this browsing retards the rate, apparently quite slow anyway, at which stands succeed to conifer dominance.

Cattle pressure on stands of these moist environments in late summer can be appreciable; they seek and find both thermal cover and forage. Their impacts constitute the single greatest threat to maintenance of this vegetation type for its biodiversity value, that of a relatively unaltered state. A synopsis of field notes indicates that by mid-August most stands have been entered and trampled. It appears certain that localized areas, including but not restricted to e.g. South Fork of Milk River mostly east of Hw. 89 and lower elevations in the vicinity of Kiowa, have experienced continuous and heavy grazing, which results in yearly forage removal of $80 \%$ plus of the standing crop in forb-dominated undergrowth conditions.

We speculate that this intense grazing pressure is responsible for the highly, altered composition of the aspen parkland in certain localities, even of these moist to wet stands. In the most highly affected areas we noted the rhizomatous, non-native grasses Poa pratensis (Kentucky bluegrass) and Phleum pratense (timothy) to have become undergrowth dominants, to the near exclusion of all but relatively unpalatable vegetation such as Symphoricarpos albus (common snowberry), Ribes setosum (Missouri 

gooseberry), Achillea millefolium (common yarrow), Geranium richardsonii (Richardson's geranium), Geranium viscossisimum (sticky geranium), Ranunculus uncinatus (little buttercup). In small disturbed areas dense patches of weeds such as Urtica dioica (stinging nettle) and Cirsium anvense (Canada thistle) have developed.

Field notes taken in the summer of 1996 confirmed previous impressions that several forbs are grazed preferentially by cattle, these being Angelica arguta (sharptooth angelica), Osmorhiza occidentalis (western sweetcicely), Heracleum lanatum (cow parsnip) and Veratrum viride (green false hellebore). Based on their position in the landscape we have reason to believe that the areas referred to in the paragraph above would have supported extensive populations of the above-named species, whereas portions of these areas are now converted to a less desirable status. Though coincidental, it is none the less significant that all these heavily-grazed species constitute grizzly bear (Ursus arctos) forage as well, their importance varying by season. There is clear overlap in the diets of cattle and grizzly bears and management strategies should address these conflicting needs.

Lynch (1955) speculated that the high sheep numbers that apparently were present in earlier times were responsible for aspen never getting beyond the root sprout stage in aspen openings and at the edge of groves and thus prevented parkland expansion. Though purely speculative, it is quite conceivable that intensive sheep grazing in previous times could be responsible for missing age (size) classes in some stands. We found no sheep pellets in our stands or in the vicinity and noted no evidence for their browsing on aspen sprouts and thus presume sheep numbers have been reduced; we took no data that bear on parkland expansion, or lack therof. 



\section{Rare Plant Species/Floristics}

We did not find threatened, endangered, or sensitive plant species in trembling aspen habitat, but do not rule out the possibility. The fieldwork focus on sampling homogeneous stands may overlook the microhabitat features that rare species occupy, inset within the stands and the overall landscape.

Eight tree species, 29 shrub species, 28 graminoids and 82 forbs, ferns, and fern allies combine for a total of 147 vascular plant species found on the sample plots (complete list Appendix F), which is fewer than the number of species than can be expected for the aspen parkland as a whole (considering that the more xeric portions of the moisture gradient were not sampled). Species richness averaged 38 species per plot, which is quite high for forest vegetation east of the Continental Divide in Montana. Coniferous forest types in this same landscape average between $15-27$ species per plot. Within drier aspen types, generally fewer than $\mathbf{2 4}$ species are recorded per plot. In terms of preserving the diversity of forested habitats, the moist to wet segment of the BIR parkland is a highly significant component of the Rocky Mountain Front. 



\section{CONCLUSIONS}

In the course of a partial summer's field sampling we acquired a data base sufficient to permit refining of the deciduous dominated forest portions of three previous community classifications (Lynch 1955, Cooper and Pfister 1981, Hansen et al. 1995); our classification circumscribes three most mesic to wet community types of the BIR, Populus tremuloides / Cornus stolonifera, P. tremuloides / Calamagrostis canadensis and $P$. tremuloides / Osmorhiza occidentalis. The BIR wetlands and moist uplands dominated by trembling aspen and black cottonwood communities are uncommon regarding their composition and possibly unique because of the generally high quality of their occurrences. Plant associations characteristic of the wettest sites, P. tremuloides / Cornus stolonifera and $P$. tremuloides / Calamagrostis canadensis, are rated by the Heritage Program as S3 and G3 regarding their rarity, with threats to their long-term existence factored in as well.

The POPTRE/OSMOCC association, rated G2/S2, is ostensibly the most geographically restricted and exceptional of the three community types and also under the greatest threat. Regarding composition and condition we have not established unequivocally that POPTRE/OSMOCC is unique (this would require sampling in the Canadian portion of the parkland) and in fact this community type bears a strong floristic and structural resemblance to and occupies similar habitats, soils, and positions in the landscape as does the $P$. tremuloides / tall forb community type of the Intermountain Region defined by Mueggler (1988). There is approximately a 250-300 mile gap between the northernmost example of $P$. tremuloides / tall forb in the Middle Rocky Mountains and the southernmost occurrence of $P$. tremuloides / Osmorhiza occidentalis in the Northern Rocky Mountains. There is a steep floristic cline over this considerable geographic expanse. Despite the more than superficial ecological resemblance of the two communities we believe they are sufficiently different, especially in regard to geographic setting and floristic composition, to regard them as unique types.

Cattle, through excessive grazing, trampling, and weed introduction, have negatively impacted some POPTRE/OSMOCC sites and constitute the greatest ongoing threat to this community, but overall these moister sites are in good condition. We suggest that establishing cattle exclosures, appropriately placed and sized so a to capture a range of aspen-black cottonwood habitat conditions, would be effective in estimating both the impact of cattle through vegetation trends and the overlap between cattle and ungulate or grizzly bear use.

All three community types are climax associations to a degree that appears inversely related to increasing dryness on the moisture gradient. We noted in passing that the drier upland aspen-dominated communities had much more evidence of the incursion of conifers, mostly Douglas-fir (Pseudotsuga menziesii). These aspen and black cottonwood stands are self-perpetuating, their tree populations apparently being longterm stable. This is not a unique condition for aspen but is definitely the exception to most successional scenarios in this vegetation type. Fungal and bacterial diseases and 

insect pathogens are ubiquitous and limit tree longevity and stand productivity (the tree portion thereof) but the suckering ability of both Populus spp. provides a relatively constant source of recruitment to the canopy layer.

An examination of reports and classifications from adjacent areas, which have been less intensively sampled and with somewhat different techniques, indicates that the aspen parkland of the BIR has a relatively severe climate as reflected by the short, wind-trimmed trees and that the undergrowth is especially forb-rich. Species richness averaged 38 species per plot, which is high for forested types. Coniferous community types in this same landscape average between 15 and 27 species per plot. In terms of preserving the diversity of forested habitats alone, this BIR parkland should be a strong focus of efforts.

Additionally, much of the aspen lowland is both subirrigated and in position to receive overland flow and could constitute an appreciable area of palustrine, broad-leaved deciduous, forested wetland in the Cowardin et al. (1977) classification and a "jurisdictional wetland" in the scheme of the "Corps of Engineers Wetlands Delineartion Manual" (Environmental Laboratory 1987). We have documented that two plant associations, $P$. tremuloides/Comus stolonifera and $P$. tremuloides/Calamagrostis canadensis, are almost invariably associated with wetland conditions. The third association, $P$. tremuloides / Osmorhiza occidentalis, occurs as a jurisdictional wetland in about $20 \%$ of the cases. The fact that these plant associations are so predictably associated with jurisdictional wetlands makes them valuable surrogates for mapping wetlands without having to resort to excavating soil pits or hypothesizing about hydrologic regimes. Values typically associated with such wetlands include flood mitigation (floodwater storage), water quality improvement (capture of nutrients and erosion from uplands), storm abatement and aquifer recharge, aesthetics, and perhaps most importantly critical wildlife habitat.

This moist to wet habitat is potentially critical to avian productivity (Tewksbury 1997). It also contains an abundance of grizzly bear foods (herbs), such as sharptooth angelica (Angelica arguta), western sweet-cicely (Osmorhiza occidentalis), cow-parsnip (Heracleum lanatum), glacier lily (Erythronium grandiflorum), field horsetail (Equisetum arvense). In light of the demise of many stands of whitebark pine (Pinus albicaulis) in adjacent Glacier National Park, these aspen parklands may sustain more pressure from the grizzly bear population, though aspen parkland stands generally serve as springearly summer forage sites and not fall sites, as do the whitebark pine stands. Other wildlife species frequent these habitats but determination of intensity and types of use were beyond this study's scope. 


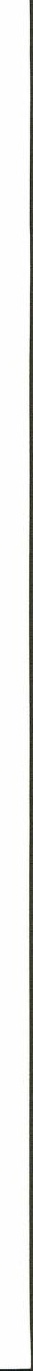




\section{LITERATURE CITED}

Bird, R. D. 1961. Ecology of the aspen parkland of western Canada. Contribution No. 27, Research Station, Canada Department of Agriculture. Winnipeg. Manitoba, Canada. $155 \mathrm{pp}$.

Daubenmire, R. 1959. Canopy coverage method of vegetation analysis. Northwest Science 33: 43-64.

Environmental Laboratory. 1987. Corps of Engineers wetlands delineation manual. Technical Report Y-87-1. U. S. Army Engineer Waterways Experiment Station, Vicksburg, MS. $100 \mathrm{pp}$.

Hagle, S. K., S. Tunnock, K. E. Gibson and C. J. Gilligan. 1990. Field guide to diseases and insect pests of Idaho and Montana forests. Publication No. R1-8954. U. S. Department of Agriculture, Forest Service, State and Private Forestry, Northern Region, Missoula, MT. 123 pp.

Hansen, P. L, R. D. Pfister, K. Boggs, B. J. Cook, J. Joy, and D. K. Hinckley. 1995. Classification and management of Montana's riparian and wetland sites. Miscellaneous Publication No. 54, Montana Forest and Conservation Experiment Station, School of Forestry, University of Montana, Missoula, MT. 646 pp.

Hill, M. O. 1979a. DECORANA-A FORTRAN Program for detrended correspondence analysis and reciprocal averaging. Ithaca, NY: Cornell University.

Hill, M. O. 1979b. TwINSPAN - A FORTRAN program for arranging multivariate data in a ordered two-way table by classification of the individuals and attributes. Ithaca, NY. Cornell University.

Hinds, T. E. 1985. Diseases. In Aspen: Ecology and Management in the western United States. Eds. N.V. DeByle and R. P. Winokur. U. S. Forest Service, General Technical Report RM-119, Rocky Mountain Forest and Range Experiment Station, Fort Collins, CO. pg. 87-106.

Hiratsuka, Y., T. Stokes, P. Chakravarty, and D. J. Morgan. 1995. A field guide to classify and measure aspen decay and stain. Special Report 4, Canadian Forest Service Northwest Region, Northern Forestry Centre, Edmonton, Alberta, Canada. . $27 \mathrm{pp}$.

Hitchcock, C. L. and A. Cronquist. 1973. Flora of the Pacific Northwest. University of Washington Press, Seattle. 730 pp. 

Kay, C. E. and F. H. Wagner. 1994. Historical condition of woody vegetation on

Yellowstone's Northern Range: A critical evaluation of the "natural regulation" pardigm. Ed. D. G. Despain. In Plants and their environments: Proceedings of the first biennial scientific conference on the Greater Yellowstone Ecosystem. Technical Report NPS/NRYELL/NRTR-93/XX. 15

Lynch, D. 1955. Ecology of the aspen groveland in Glacier County, Montana. Ecological Monographs 25 (4): 321-344.

Moss, E. H. 1955. The vegetation of Alberta IV. The poplar association and related vegetation of central Alberta. Journal of Ecology 20: 380-415.

Mueggler, W. F. 1988. Aspen community types of the Intermountain Region. U. S. Department of Agriculture, Forest Service General Technical Report INT-250. Intermountain Research Station, Ogden, UT. $135 \mathrm{pp}$.

Mutel, C. F. 1973. An ecological study of the plant communities of certain montane meadows in the Front Range of Colorado. Unpublished Thesis, University of Colorado, Boulder. $77 \mathrm{pp}$.

Oliver, C. D. and B. C. Larson. 1996. Forest stand dynamics. John Wiley \& Sons, Inc. $520 \mathrm{pp}$.

Pfister, R. D., B. L. Kovalchik, S. F. Arno, and R. C. Presby. 1977. Forest habitat types of Montana. U. S. Department of Agriculture, Forest Service General Technical Report INT-34. Intermountain Forest and Range Experiment Station, Ogden, UT. $175 \mathrm{pp}$.

Powell, D. C. 1988. Aspen community types of the Pike and San Isabel National Forests in south-central Colorado. U. S. Department of Agriculture, Forest Service, Rocky Mountain Region, Report R2-ECOL-88-01. 254 pp.

Reed, P. B. Jr. 1988a. National list of plant species that occur in wetlands: North Plains (Region 4). U. S. Fish and Wildlife Service Biological Report 88 (26.4). U. S. Department of Interior, Fish and Wildlife Service, Research and Development, Washington, DC. 64 pp.

Reed, P. B. Jr. 1988b. National list of plant species that occur in wetlands: Norhtwest (Region 9). U. S. Fish and Wildlife Service Biological Report 88 (26.9). U. S. Department of Interior, Fish and Wildlife Service, Research and Development, Washington, DC. 89 pp.

Tewksbury, J. 1997. Riparian forests and avian productivity. Report prepared for U. S. Forest Service, Intermountain Research Station, Missoula, MT. 61 pp. 


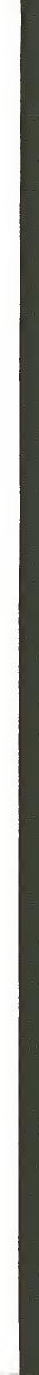


USDA Soil Conservation Service and USDI Bureau of Indian Affairs. 1980. Soil Survey of Glacier County Area and Part of Pondera County, Montana. Bozeman, MT. 161 pp plus maps and plates. 

APPENDIX A. BLACKEEET INDIAN RESERVATION TREMBLING ASPEN-BLACK COTTONWOOD COMMUNITIES $\star$ Cover Synthesis (Stand) Table $\star$

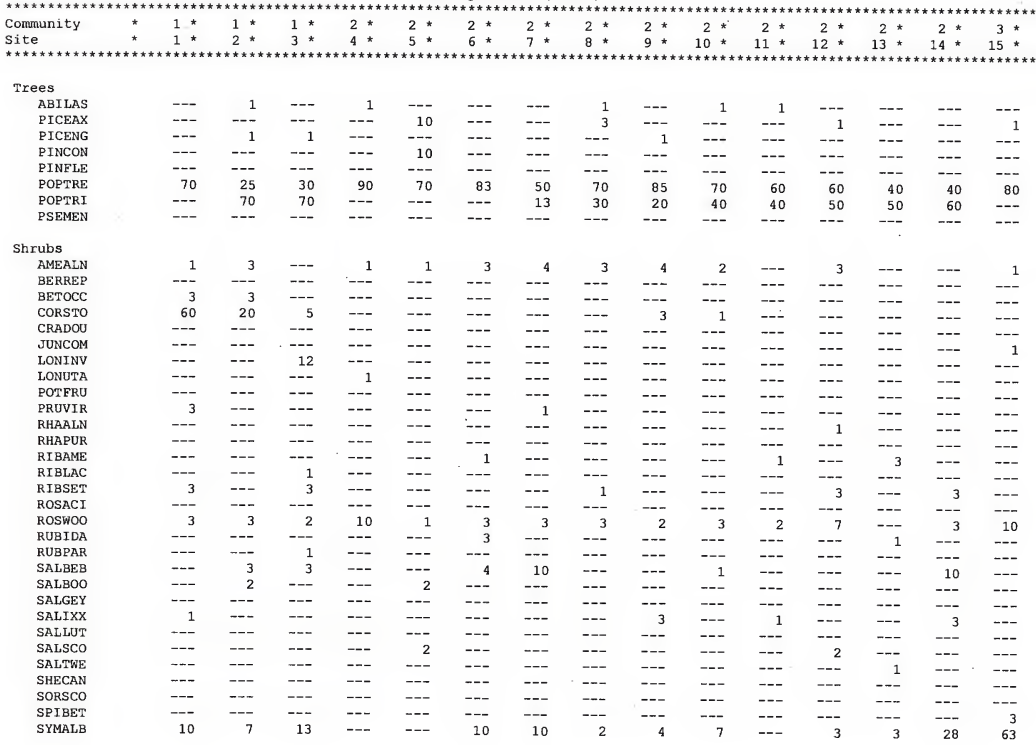


APPENDIX A. BLACKEEET INDIAN RESERVATION TREMBLING ASPEN-BLACK COTTONWOOD COMMUNITIES * Cover Synthesis (Stand) Table *

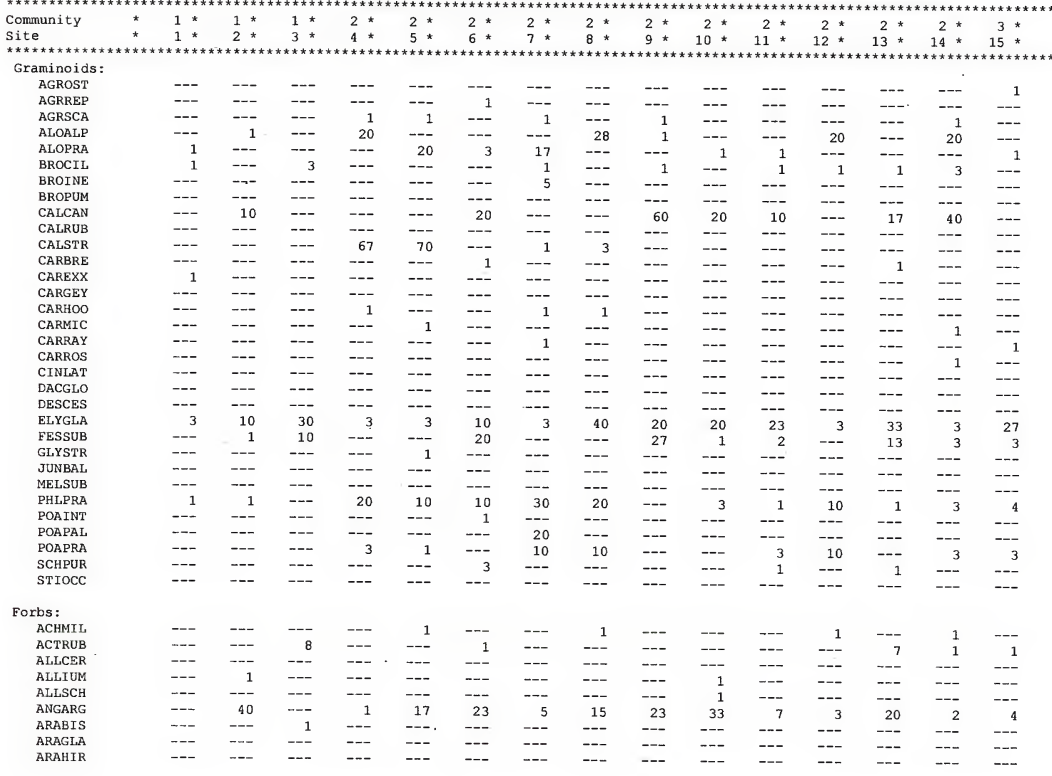



APPENDIX A. BLACKEEET INDIAN RESERVATION TREMBLING ASPEN-BLACK COTTONWOOD COMMUNITIES * Cover Synthesis (Stand) Table *

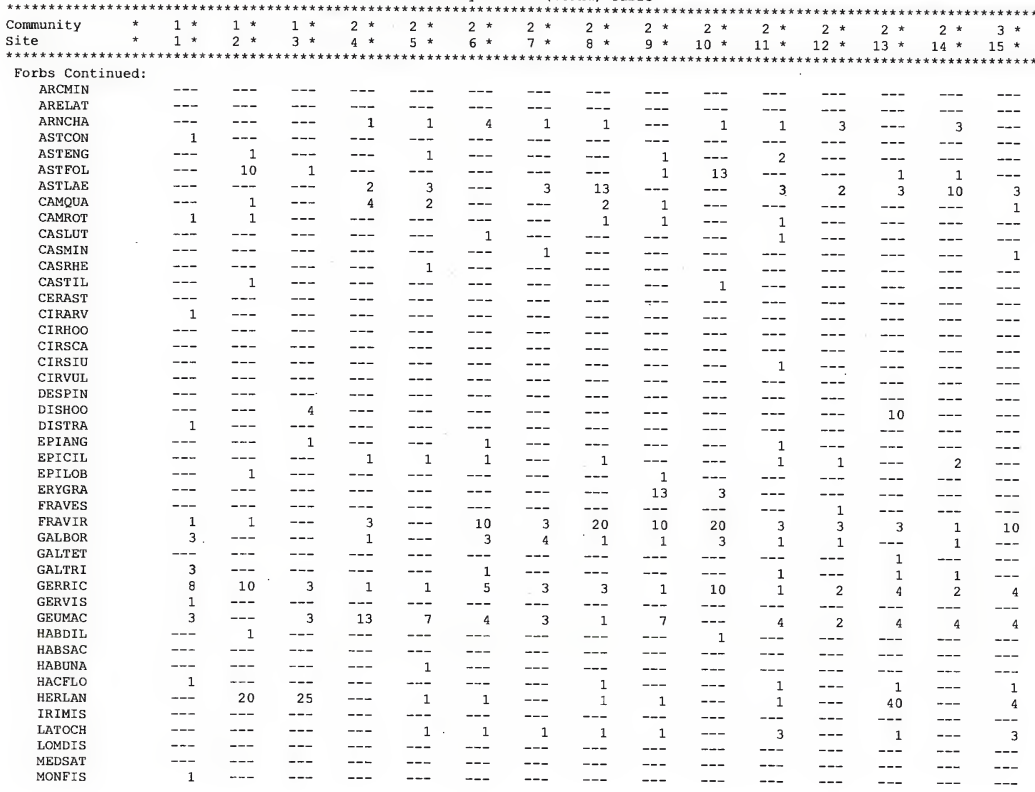



APPENDIX A. BLACKFEET INDIAN RESERVATION TREMBLING ASPEN-BL.ACK COTTONWOOD COMMUNITIES * Cover Synthesis (Stand) Table *

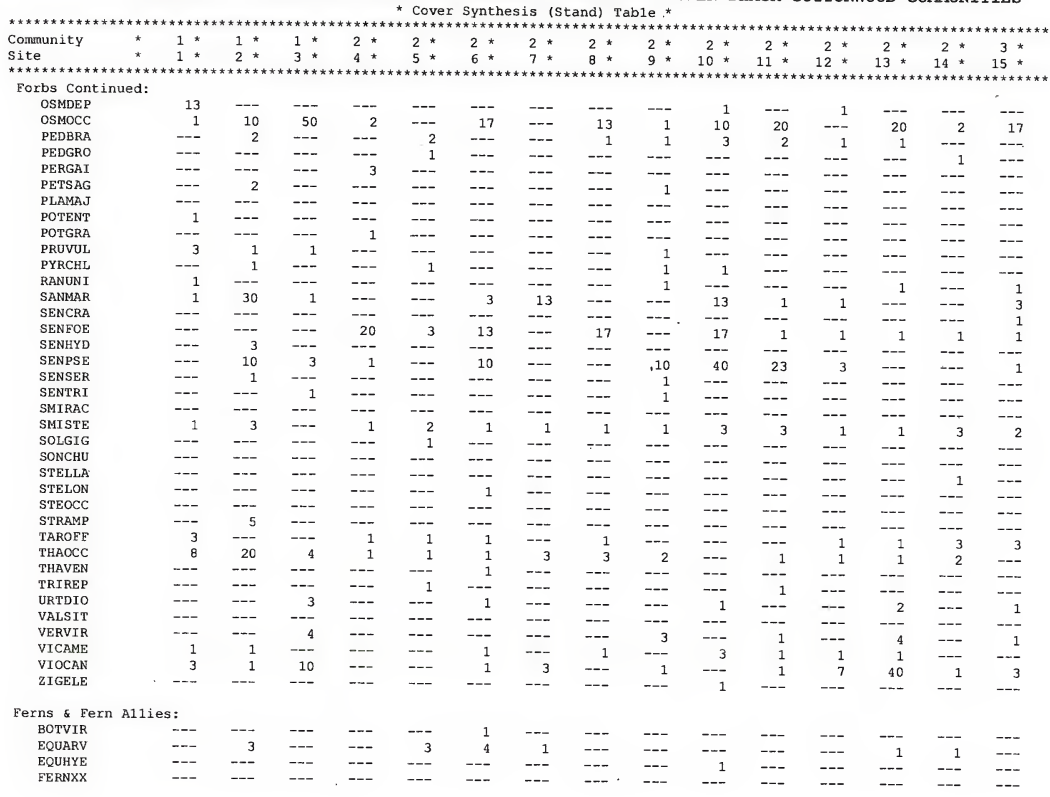



APPENDIX A. BLACKEEET INDIAN RESERVATION TREMBLING ASPEN-BLACK COTTONWOOD COMMUNITIES * Cover Synthesis (Stand) Table*

\begin{tabular}{|c|c|c|c|c|c|c|c|c|c|c|c|c|c|c|c|}
\hline Community & $3 *$ & $3 *$ & $3 *$ & 3 * & $3 *$ & $3 *$ & 3 & $3 *$ & 3 * & $3 \star$ & $3 *$ & 3 * & $3 *$ & $3 *$ & * \\
\hline site & $16 *$ & $17 \star$ & 18 & 19 * & $20 *$ & $21 *$ & 22 & $23 *$ & 24 * & $25 *$ & 26 * & $27 *$ & $28 *$ & $29 *$ & 30 \\
\hline & & & & & & & & 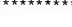 & 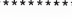 & $\hbar \star \star \star$ & 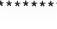 & ఓ $\star \star$ & 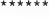 & $* * *$ & \\
\hline \multicolumn{16}{|l|}{ Trees: } \\
\hline ABI LAS & 3 & --- & --- & --- & --- & -- & 1 & --- & --- & -- & 1 & 1 & -- & --- & --- \\
\hline PICEAX & 1 & 1 & -- & 1 & 1 & -- & -- & --- & 1 & -- & 3 & 2 & --- & -- & --- \\
\hline PICENG & -- & --- & -- & --- & --- & 3 & -- & 13 & --- & -- & --- & --- & -- & --- & --- \\
\hline PINCON & -- & --- & -- & --- & --- & --- & --- & -- & --- & -- & $\therefore-$ & -- & --- & --- & --- \\
\hline PINFLE & -- & -- & --- & -- & --- & -- & -- & --- & --- & --- & --- & 1 & --- & --- & --- \\
\hline POPTRE & 90 & 80 & 83 & 83 & 83 & 80 & 55 & 73 & 80 & 50 & 83 & 90 & 50 & 50 & 38 \\
\hline POPTRI & -- & --- & --- & 1 & 1 & 1 & 1 & 2 & 10 & 10 & 20 & 23 & 30 & 20 & 30 \\
\hline PSEMEN & -- & --- & --- & 3 & --- & --- & --- & --- & -- & -- & --- & --- & -- & --- & -- \\
\hline \multicolumn{16}{|l|}{ Shrubs: } \\
\hline AMEALN & 2 & -- & 3 & 3 & 13 & 2 & --- & 1 & 3 & 23 & 1 & 1 & --- & 1 & --- \\
\hline BERREP & --- & --- & --- & -- & 3 & 1 & --- & --- & 1 & 1 & 4 & 4 & --- & 1 & -- \\
\hline BETOCC & -- & -- & --- & --- & -- & -- & --- & 2 & -- & --- & -- & 1 & --- & --- & 1 \\
\hline CORSTO & --- & --- & -- & --- & 1 & 1 & 1 & $-r-$ & --- & -- & 2 & --- & -- & --- & 3 \\
\hline CRADOU & -- & --- & --- & --- & -- & -- & -- & --- & --- & 3 & -- & --- & -- & --- & $-\cdots$ \\
\hline JUNCOM & -- & --- & --- & -- & --- & --- & $\rightarrow-$ & 1 & -- & --- & --- & $-\cdots$ & --- & -- & $-\cdots$ \\
\hline LONINV & -- & -- & -- & --- & --- & -- & --- & -- & --- & -- & --- & --- & 1 & --- & --- \\
\hline LONUTA & $-\infty$ & --- & --- & --- & --- & --- & --- & --- & --- & --- & --- & --- & --- & --- & -- \\
\hline POTFRU & -- & 1 & --- & --- & --- & --- & --- & --- & --- & --- & --- & --- & -- & -- & --- \\
\hline PRUVIR & -- & -- & -- & --- & 1 & -- & --- & --- & --- & --- & --- & --- & --- & --- & -- \\
\hline RHAALN & --- & --- & --- & --- & --- & --- & --- & --- & --- & --- & --- & --- & $-\infty$ & --- & --- \\
\hline RHAPUR & -- & -- & --- & --- & -- & --- & --- & --- & --- & 1 & --- & --- & 1 & --- & --- \\
\hline RIBAME & $-\cdots$ & --- & --- & -- & -- & --- & --- & --- & -- & --- & --- & -- & 1 & --- & -- \\
\hline RIBLAC & -- & -- & --- & -- & -- & --- & --- & --- & --- & -- & --- & --- & --- & --- & -- \\
\hline RIBSET & --- & --- & -- & 3 & --- & --- & --- & --- & --- & --- & --- & --- & --- & --- & -- \\
\hline ROSACI & -- & --- & -- & -- & --- & 1 & --- & --- & --- & 1 & --- & --- & --- & --- & -- \\
\hline ROSWOO & 3 & 13 & 1 & -- & 10 & $-m-$ & -- & 13 & 13 & -- & 20 & 10 & --- & 3 & 1 \\
\hline $\begin{array}{l}\text { RUBIDA } \\
\text { RUBPAR }\end{array}$ & 40 & $\begin{array}{l}--- \\
---\end{array}$ & --- & --- & -- & -- & --- & --- & --- & -- & -- & --- & 1 & --- & -- \\
\hline $\begin{array}{l}\text { RUBPAR } \\
\text { SALBEB }\end{array}$ & --- & $-\cdots$ & -- & --- & --- & -- & 27 & -- & -- & -- & --- & --- & -- & --- & 30 \\
\hline SALBOO & --- & 2 & -- & -- & --- & --- & -- & --- & --- & -- & --- & -- & -- & -- & $+m$ \\
\hline SALGEY & -- & 2 & --- & -- & --- & -- & --- & -- & -- & --- & --- & $\begin{array}{r}1 \\
---\end{array}$ & -- & --- & -- \\
\hline SALIXX & --- & -- & --- & --- & 17 & --- & 3 & 3 & -- & - & -- & -- & -- & 1 & -- \\
\hline SALLUT & --- & --- & -- & --- & -- & -- & -- & $\ldots$ & 1 & -- & -- & -- & 3 & $\begin{array}{r}1 \\
--\end{array}$ & -- \\
\hline SALSCO & -- & --- & 3 & --- & --- & --- & --- & 3 & -- & --- & 7 & 2 & -- & -- & 1 \\
\hline SALTWE & --- & -- & $-\cdots$ & $\cdots$ & --- & --- & --- & --- & --- & --- & -- & -- & -. & -- & -- \\
\hline SHECAN & $m$ & $-\cdots$ & --- & --- & 3 & --- & --- & 1 & --- & -- & 1 & 1 & -- & --- & --- \\
\hline SORSCO & 1 & -- & --- & -- & -- & -- & --- & --- & --- & --- & --- & --- & --- & --- & -- \\
\hline SPIBET & --- & --- & -- & -- & -- & 7 & --- & --- & --- & 13 & --- & --- & --- & 1 & -- \\
\hline SYMALB & 40 & -- & 30 & 60 & 50 & 30 & 2 & 30 & 30 & 50 & 50 & 60 & 3 & 17 & \\
\hline
\end{tabular}



APPENDIX A. BLACKFEET INDIAN RESERVATION TREMBLING ASPEN-BLACK COTTONWOOD COMMUNITIES * Cover Synthesis (Stand) Table *

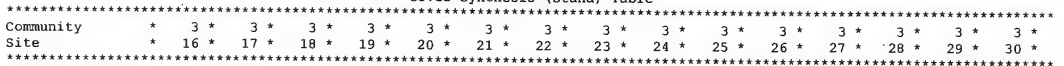

\begin{tabular}{|c|c|c|c|c|c|c|c|c|c|c|c|c|c|c|c|}
\hline \multicolumn{16}{|l|}{ Graminoids : } \\
\hline AGROST & -- & --- & -- & -- & --- & --- & --- & --- & --- & --- & --- & --- & --- & --- & $-\cdots$ \\
\hline AGRREP & --- & --- & -- & -- & --- & --- & --- & --- & --- & -- & 1 & --- & --- & -- & --- \\
\hline AGRSCA & $-\infty$ & --- & --- & -- & -- & -- & --- & --- & -- & --- & --- & --- & --- & -- & -- \\
\hline ALOALP & -- & 13 & --- & --- & --- & -- & --- & -- & --- & --- & --- & -- & -- & -- & --- \\
\hline ALOPRA & -- & --- & --- & -- & -- & -- & -- & -- & 1 & -- & -- & --- & --- & -- & --- \\
\hline BROCIL & 1 & 3 & 3 & 2 & 2 & 1 & 1 & --- & 1 & 3 & 1 & 1 & 1 & 20 & --- \\
\hline BROINE & --- & --- & -- & --- & --- & --- & 1 & --- & --- & --- & --- & --- & --- & -- & -- \\
\hline BROPUM & -- & --- & 1 & -- & -- & --- & -- & --- & -- & --- & --- & -- & -- & -- & --- \\
\hline CALCAN & -- & --- & 1 & --- & -- & 3 & -- & --- & --- & 3 & --- & --- & 3 & 2 & -- \\
\hline CALRUB & --- & $-\cdots$ & 1 & --- & 3 & --- & -- & --- & --- & 1 & --- & 23 & --- & -- & --- \\
\hline CALSTR & --- & --- & --- & -- & --- & --- & -- & --- & --- & --- & --- & 1 & -- & --- & --- \\
\hline CARBRE & --- & --- & -- & --- & -- & --- & --- & -- & --- & --- & --- & -- & -- & $\cdots$ & -- \\
\hline CAREXX & $\cdots$ & --- & 1 & --- & 1 & -- & --- & 1 & --- & -- & --- & --- & -- & -- & --- \\
\hline CARGEY & 1 & -- & -- & -- & -- & --- & --- & --- & --- & -- & --- & -- & -- & -- & --- \\
\hline CARHOO & --- & -- & --- & --- & --- & --- & --- & --- & --- & -- & --- & -- & -- & -- & --- \\
\hline CARMIC & -+- & -- & -- & -- & -- & --- & --- & --- & -- & --- & -- & 1 & -- & -- & -- \\
\hline CARRAY & --- & --- & --- & $-\infty$ & -- & --- & -- & -- & --- & --- & --- & --- & --- & --- & --- \\
\hline CARROS & -- & -- & --- & --- & -- & --- & --- & --- & --- & --- & --- & --- & --- & -- & $\cdots$ \\
\hline CINLAT & -- & -- & -- & $-\cdots$ & --- & -- & -- & -- & --- & --- & --- & --- & 1 & -- & --- \\
\hline DACGLO & -- & -- & -- & -- & -- & 1 & --- & --- & -- & --- & --- & --- & --- & $\cdots$ & -.- \\
\hline DESCES & -- & -- & -- & $-\overline{30}$ & --- & $-\cdots-$ & -- & 1 & --- & --- & --- & --- & $-\cdots$ & -- & $\cdots$ \\
\hline ELYGLA & 7 & 20 & 4 & 30 & 10 & 20 & 40 & 3 & 17 & 20 & 10 & 7 & 27 & 10 & 3 \\
\hline FESSUB & 2 & -- & --- & 3 & -- & 10 & 3 & --- & -- & 13 & 2 & 3 & 13 & 1 & 1 \\
\hline GLYSTR & -- & $\cdots$ & --- & -- & --- & --- & --- & --- & --- & -- & --- & --- & --- & -- & -- \\
\hline JUNBAL & -- & -- & -- & --- & -- & -- & --- & -- & --- & --- & -- & --- & --- & $\cdots$ & $-\cdots$ \\
\hline MELSUB & -- & -- & 13 & --- & --- & -- & --- & --- & -- & -- & --- & -- & --- & -- & --- \\
\hline PHLPRA & 1 & 15 & 1 & 10 & 10 & --- & 10 & 3 & 3 & -- & --- & -- & -- & 3 & -- \\
\hline POAINT & -- & $\cdots$ & 1 & -- & -- & -- & -- & -- & -- & --- & --- & -- & --- & $\cdots$ & -- \\
\hline POAPAL & --- & $-\overline{20}$ & --- & -- & - & -- & --- & 1 & -- & -- & -- & --- & $\cdots$ & -- & --- \\
\hline POAPRA & -- & 20 & -- & 10 & 10 & 1 & -- & 3 & -- & -- & 1 & 10 & -- & 1 & -- \\
\hline SCHPUR & $\begin{array}{r}1 \\
--\end{array}$ & --- & --- & $\begin{array}{r}1 \\
--\end{array}$ & 1 & -- & 1 & -- & 17 & 3 & 1 & 3 & 1 & $\cdots$ & $\cdots$ \\
\hline STIOCC & $\cdots$ & $\cdots$ & $\cdots$ & --- & -- & --- & --- & --- & -- & --- & --- & 1 & --- & -- & -- \\
\hline \multicolumn{16}{|l|}{ Forbs: } \\
\hline ACHMIL & --- & 1 & 1 & 1 & -- & --- & 1 & 1 & 1 & --- & --- & 1 & --- & $\cdots$ & -- \\
\hline ACTRUB & $\cdots$ & - & 1 & --- & --- & 3 & --- & --- & --- & 1 & --- & --- & 1 & 1 & 7 \\
\hline ALLCER & -- & 1 & -- & -- & -- & -- & --- & --- & $\begin{array}{r}1 \\
---\end{array}$ & -- & -- & --- & --- & $\cdots$ & $\cdots$ \\
\hline ALLIUM & -- & --- & --- & -- & --- & -- & --- & -- & -- & -- & -- & -- & --- & $\cdots$ & --- \\
\hline ALLSCH & $-\overline{1}$ & $--\overline{3}$ & -- & $-\overline{3}$ & $-\overline{15}$ & $--\overline{7}$ & ,-- & $\overline{10}$ & --- & -- & --- & --- & --- & -- & --- \\
\hline ANGARG & $\begin{array}{r}1 \\
---\end{array}$ & $\begin{array}{r}3 \\
--\end{array}$ & 4 & 3 & $\begin{array}{r}15 \\
---\end{array}$ & 7 & 15 & 10 & 1 & 1 & 4 & 4 & 7 & 3 & 1 \\
\hline $\begin{array}{l}\text { ARABIS } \\
\text { ARAGLA }\end{array}$ & -- & --- & 1 & -- & --- & --- & --- & -- & --- & --- & $-\overline{-}$ & -- & -- & -- & -- \\
\hline $\begin{array}{l}\text { ARAGLA } \\
\text { ARAHI R }\end{array}$ & -- & -- & $\begin{array}{r}1 \\
---\end{array}$ & -- &.-- & 1 & -- & --- & --- & $--\overline{1}$ & --- & --- & -- & $\cdots$ & -- \\
\hline & & & & & & & -- & . & . & 1 & -+ & $\cdots$ & -- & $\cdots$ & --- \\
\hline
\end{tabular}



APPENDIX A. BLACKFEET INDIAN RESERVATION TREMBLING ASPEN-BLACK COTTONWOOD COMMUNITIES * Cover Synthesis (Stand) Table *

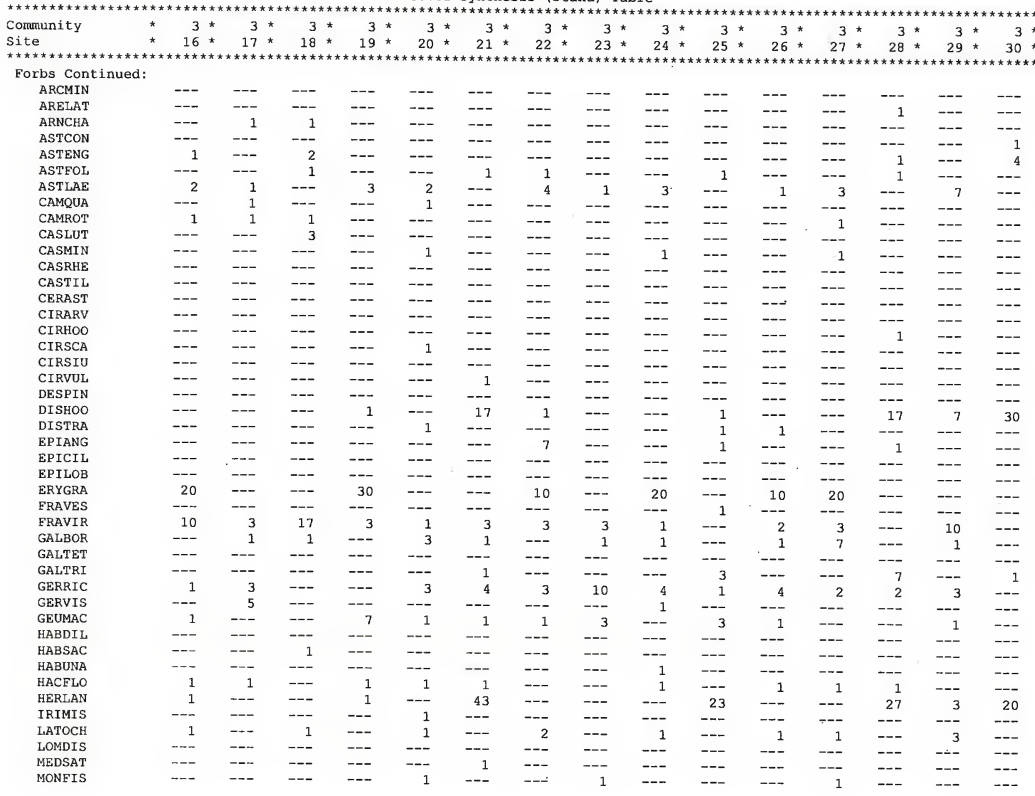



APPENDIX A. BLACKFEET INDIAN RESERVATION TREMBLING ASPEN-BLACK COTTONWOOD COMMUNITIES * Cover Synthesis (Stand) Table *

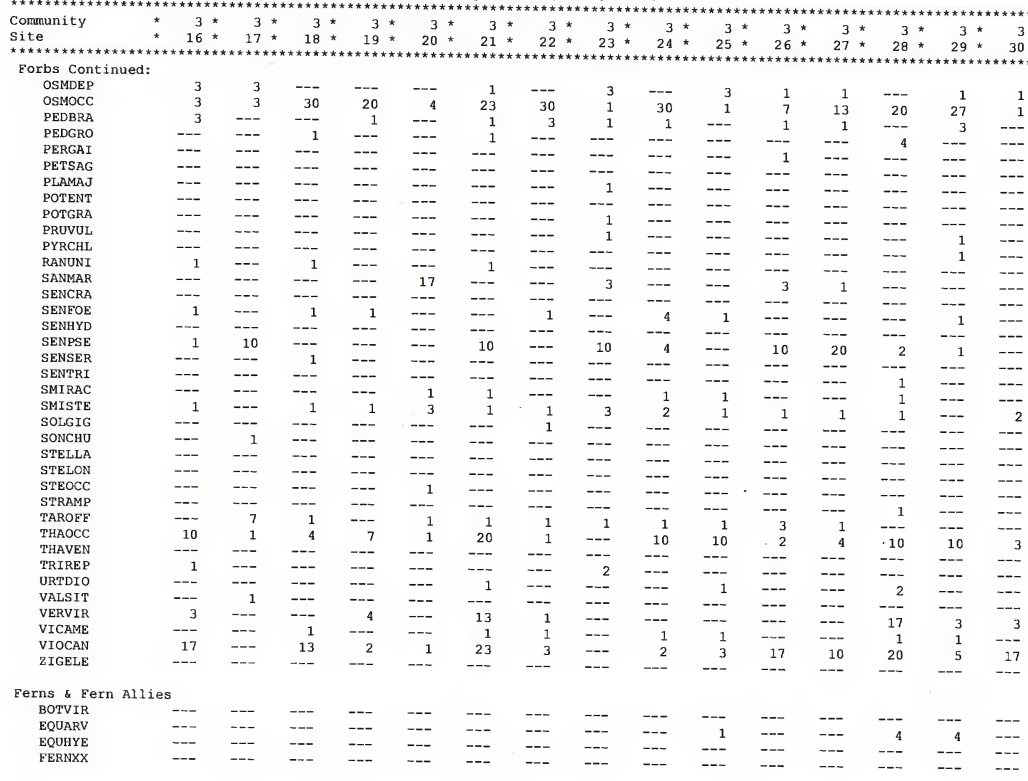



APPENDIX A. BLACKFEET INDIAN RESERVATION TREMBLING ASPEN-BLACK COTTONWOOD COMMUNITIES * Cover Synthesis (Stand) Table *

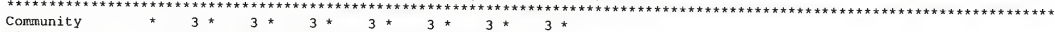
Site

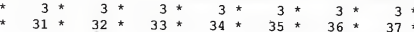

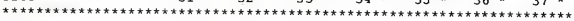

Trees

ABILAS

PICEAX

PICENG

PINCON

PINELE

POPTRE

POPTRI

PSEMEN

$\begin{array}{rrrrrrr}--- & --- & 1 & 1 & 1 & --- & --- \\ --- & --- & 1 & --- & 4 & --- & --- \\ --- & -- & --- & --- & --- & --- & 1 \\ -- & --- & --- & --- & --- & --- & --- \\ 50 & 30 & -- & --- & --- & --- & -- \\ 68 & 50 & 50 & 30 & 20 & 75 & 9 \\ --- & --- & --- & --- & --- & --- & ---\end{array}$

Shrubs:

AMEALN

BERREP

BETOCC

CORSTO

CRADOU

JUNCOM

LONINV

LONUTA
POTERU

PRUVIR

RHAALN

RHAPUR

RIBAME

RIBLAC

RIBSET

ROSACI

ROSWOO

RUBIDA

RUBPAR

SALBEB

SALBOO

SALGEY

SALIXX

SALLUT

SALTWE

SHECAN

SORSCO

SPIBET

SYMALB

\begin{tabular}{|c|c|c|c|c|c|c|}
\hline 2 & -- & 3 & --- & --- & 1 & 10 \\
\hline-- & -- & -- & -- & -- & -- & --- \\
\hline-- & --- & -- & -- & $\therefore-$ & -- & $-\cdots$ \\
\hline--- & 1 & -- & 3 & 1 & 1 & --- \\
\hline$\cdots$ & --- & -- & -- & -- & -- & -- \\
\hline$\cdots$ & -- & --- & $\cdots$ & --- & -- & --- \\
\hline$\cdots$ & $\cdots$ & -- & -- & $\cdots$ & -- & --- \\
\hline-- & 1 & $\cdots$ & -- & --- & -- & -- \\
\hline-- & -- & -- & -- & -- & -- & -- \\
\hline--- & $\cdots$ & -- & $-\bar{s}$ & --- & 3 & -- \\
\hline 1 & 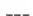 & -1 & 3 & $\cdots$ & $\cdots$ & $\cdots$ \\
\hline--- & $\ldots$ & -- & 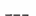 & $-x$ & -- & -- \\
\hline$\rightarrow$ & --- & -- & -- & -- & - & - \\
\hline-- & --- & -- & 3 & 1 & 1 & -- \\
\hline$\rightarrow$ & -- & -- & -- & -- & -- & -- \\
\hline 3 & -- & --- & -- & 1 & 2 & 3 \\
\hline--- & -- & $-\infty$ & -- & -- & -- & -- \\
\hline-- & 20 & -- & 27 & --- & -- & 2 \\
\hline-- & 1 & +- & -- & --- & -- & -- \\
\hline$\cdots$ & $\cdots$ & 1 & -- & 1 & -- & -- \\
\hline$\cdots$ & --- & 1 & - & & -- & -- \\
\hline$\cdots$ & $=-$ & $\cdots$ & 1 & 3 & 3 & 3 \\
\hline 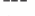 & -1 & $\cdots$ & $\cdots$ & $-x$ & +- & -- \\
\hline 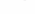 & -- & 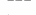 & -- & - & -- & $\cdots$ \\
\hline$=$ & 3 & $\cdots$ & -- & -- & $\cdots$ & -- \\
\hline-- & 1 & -- & -- & 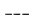 & 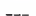 & -7 \\
\hline-- & - & --- & --- & --- & - & - \\
\hline 1 & 1 & 17 & 30 & -- & 10 & 23 \\
\hline
\end{tabular}



APPENDIX A. BLACKFEET INDIAN RESERVATION TREMBLING ASPEN-BLACK COTTONWOOD COMMUNITIES * Cover Synthesis (Stand) Table *

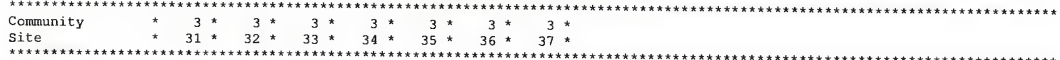

Graminoids :

AGROS

AGRREP

AGRSCA

ALOALP

ALOPRA

BROCIL

BROINE

BROPUM

CALCAN

CALRUB

CALSTR
CARBRE

CAREXX

CARGEY

CARHOO

CARMIC

CARRAY

CARROS

CINLAT

DACGLO

DESCES

ELYGLA

FESSUB

GLYSTR

JUNBAL

MELSUB

PHLPRA

POAINT

POAPAL

POAPRA

SCHPUR

\begin{tabular}{|c|c|c|c|c|c|c|}
\hline-- & -- & -- & -- & -- & -- & -- \\
\hline- & -- & --- & -- & -- & -- & -- \\
\hline-- & $-\cdots$ & 1 & --- & --- & -- & 1 \\
\hline-- & --- & 1 & -- & -- & -- & --- \\
\hline--- & --- & -- & -- & 1 & 1 & $-\cdots$ \\
\hline-- & -- & 3 & 1 & 1 & 1 & 1 \\
\hline--- & --- & --- & -- & $\cdots$ & --- & -- \\
\hline+- & -- & --- & -- & -- & -- & -- \\
\hline--- & -- & -- & 3 & $\cdots$ & 1 & 2 \\
\hline 10 & --- & --- & --- & -- & --- & 1 \\
\hline 2 & -- & 17 & -- & -- & -- & -- \\
\hline -- & - & $\cdots$ & -- & -.- & -- & -- \\
\hline 1 & $\cdots$ & -- & -- & $-\cdots$ & -- & --- \\
\hline 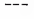 & -- & $\cdots$ & +-- & -- & -- & -- \\
\hline--- & $\cdots$ & $\cdots$ & $\cdots$ & $\cdots$ & -- & --- \\
\hline$\cdots$ & $\cdots$ & -- & $\cdots$ & -- & -- & -- \\
\hline & & -5 & $\cdots$ & $\cdots$ & $\cdots$ & 1 \\
\hline-1 & 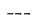 & 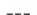 & 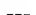 & 1 & - & $\cdots$ \\
\hline-- & -- & --- & --- & -- & 1 & - \\
\hline--- & --- & --- & -- & - & --- & -- \\
\hline 10 & 3 & 3 & 13 & 3 & 20 & 23 \\
\hline 3 & 23 & --- & 4 & -- & 10 & -- \\
\hline-- & --- & --- & -- & --- & -- & - \\
\hline$-\cdots$ & -- & --- & -- & 1 & -- & --- \\
\hline-- & -- & --- & -- & --- & --- & $\cdots$ \\
\hline 1 & --- & 10 & -- & -- & 3 & 3 \\
\hline--- & --- & -- & -- & --- & -- & --- \\
\hline- & --- & $--\overline{1}$ & -- & $\cdots$ & -- & $\cdots$ \\
\hline-- & -- & 17 & -- & --- & -- & 1 \\
\hline 3 & -- & 1 & -- & $-\cdots$ & $\cdots$ & --- \\
\hline-- & $\cdots$ & -- & $\cdots$ & $\cdots$ & -- & -- \\
\hline
\end{tabular}

Forbs:

ACHMI L

ACTRUB

ALLCER

ALLIUM

ALLSCH

ANGARG

ARABIS

ARAGLA

ARAHIR

\begin{tabular}{rrrrrrr}
--- & --- & 1 & --- & --- & --- & 1 \\
1 & 7 & --- & 2 & 1 & 10 & 1 \\
--- & --- & --- & --- & --- & --- & --- \\
--- & --- & --- & --- & --- & --- & --- \\
1 & --- & --- & --- & --- & --- & --- \\
--- & 7 & 4 & 3 & 1 & --- \\
--- & --- & --- & --- & --- & --- & --- \\
--- & 1 & --- & --- & --- & --- & --- \\
\hline-- & --- & --- & --- & ---
\end{tabular}



APPENDIX A. BLACKFEET INDIAN RESERVATION TREMBLING ASPEN-BLACK COTTONWOOD COMMUNITIES Cover Synthesis (Stand) Table *

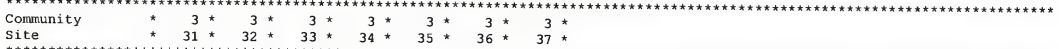

Site

Forbs Continued:

ARCMIN

ARELAT

ARNCHA

ASTCON

ASTENG

ASTFOL

A.STLAE

CAMQUA

CAMROT

CASLUT

CASMIN

CASRH:

CASTIL

CERAST

CIRARV

CIRHOO

CIRSCA

CIRSIU

CIRVUL

DESPIN

DISTRA

EPIANG

EPICIL

EPILOB

ERYGRA

FRAVES

FRAVIR

GALBOR

GALTET

GALTRI

GERRIC

GERVIS

GEUMAC

HABDIL

HABSAC

HABUNA

HACFLO

HERLAN

IRrMT

IRrmis

LATOCH

LOMDIS

MEDSAT

MONFIS

\begin{tabular}{|c|c|c|c|c|c|}
\hline-- & -- & --- & --- & -- & 2 \\
\hline-- & $-\cdots$ & -- & --- & -- & --- \\
\hline 1 & 1 & -- & --- & 1 & -- \\
\hline- & $\cdots$ & -- & --- & -- & 1 \\
\hline 3 & -- & 1 & 2 & -- & --- \\
\hline--- & 1 & -- & -- & 1 & --- \\
\hline-- & --- & 3 & 1 & 3 & -- \\
\hline-- & -- & -- & --- & 1 & -- \\
\hline-- & --- & -- & -- & --- & -- \\
\hline-- & -- & -- & --- & 1 & --- \\
\hline$\sim-$ & -- & 1 & -- & --- & -- \\
\hline-- & -- & --- & -- & -- & --- \\
\hline-- & -- & -- & -- & -- & -- \\
\hline-- & -- & --- & --- & -- & 1 \\
\hline$-\cdots$ & -- & -- & --- & --- & -- \\
\hline$\cdots$ & $\cdots$ & +- & $-\cdots$ & --- & $\cdots$ \\
\hline-- & -- & -- & -- & $\overline{--}$ & $-\infty$ \\
\hline 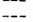 & - & 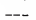 & - & -- & 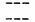 \\
\hline--- & 1 & -.- & - & -- & 1 \\
\hline--- & 25 & -- & -- & -- & - \\
\hline 1 & -- & -- & --- & --- & 1 \\
\hline-- & -- & -- & --- & -- & 1 \\
\hline--- & -- & 1 & 1 & -- & -- \\
\hline-- & -- & --- & -- & -- & -- \\
\hline-- & 1 & -- & --- & $\cdots$ & $\cdots$ \\
\hline$-\overline{3}$ & -+ & $\overline{10}$ & -- & $\overline{-1}$ & -- \\
\hline $\begin{array}{l}3 \\
2\end{array}$ & - & 3 & -- & 10 & 1 \\
\hline$-\ldots$ & $\ldots$ & -- & -- & $\begin{array}{r}1 \\
---\end{array}$ & $\begin{array}{r}1 \\
---\end{array}$ \\
\hline- & 13 & -- & 1 & -- & 10 \\
\hline 3 & 1 & 17 & 3 & 10 & 10 \\
\hline-- & -- & -- & $\cdots$ & --- & $-\cdots$ \\
\hline 1 & 1 & 3 & 1 & 2 & 20 \\
\hline-- & -- & --- & -- & -- & -- \\
\hline-- & -- & $\cdots$ & -- & $-\cdots$ & -- \\
\hline$\cdots$ & $\overline{-}$ & -- & -- & -- & $\cdots$ \\
\hline$-\overline{-}$ & 60 & -- & -- & 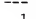 & -- \\
\hline 4 & -- & -- & 17 & 1 & 18 \\
\hline 1 & $\ldots$ & - & - & -- & $=-$ \\
\hline-- & -- & --- & $\ldots$ & -7 & -- \\
\hline- & --- & --- & -- & -- & -- \\
\hline$--\cdot-$ & $\ldots$ & 1 & -- & --- & -- \\
\hline
\end{tabular}



APPENDIX A. BLACKFEET INDIAN RESERVATION TREMBLING ASPEN-BLACK COTTONWOOD COMMUNITIES * Cover Synthesis (Stand) Table *

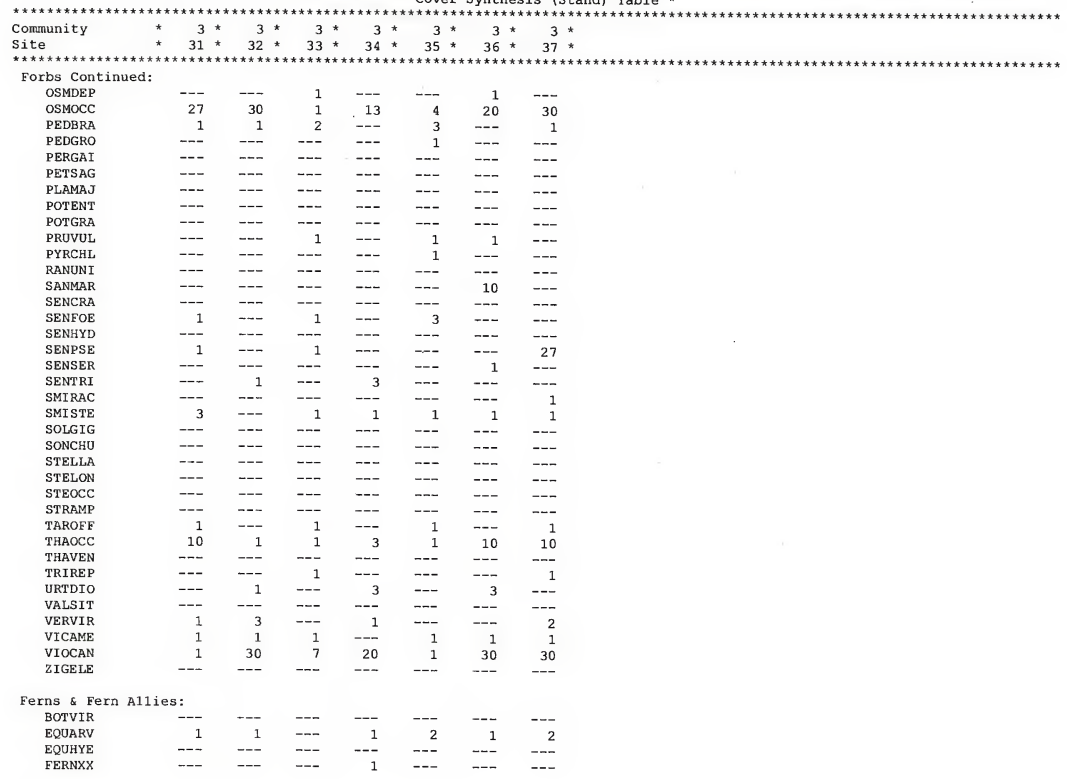


APPENDIX B. BLACKFEET INDIAN RESERVATION TREMBLING ASPEN-BLACK COTTONWOOD COMMUNITY TYPES: Cover Constancy Table: Constancy (Average Abundance) [Range, Minimum - Maximum]

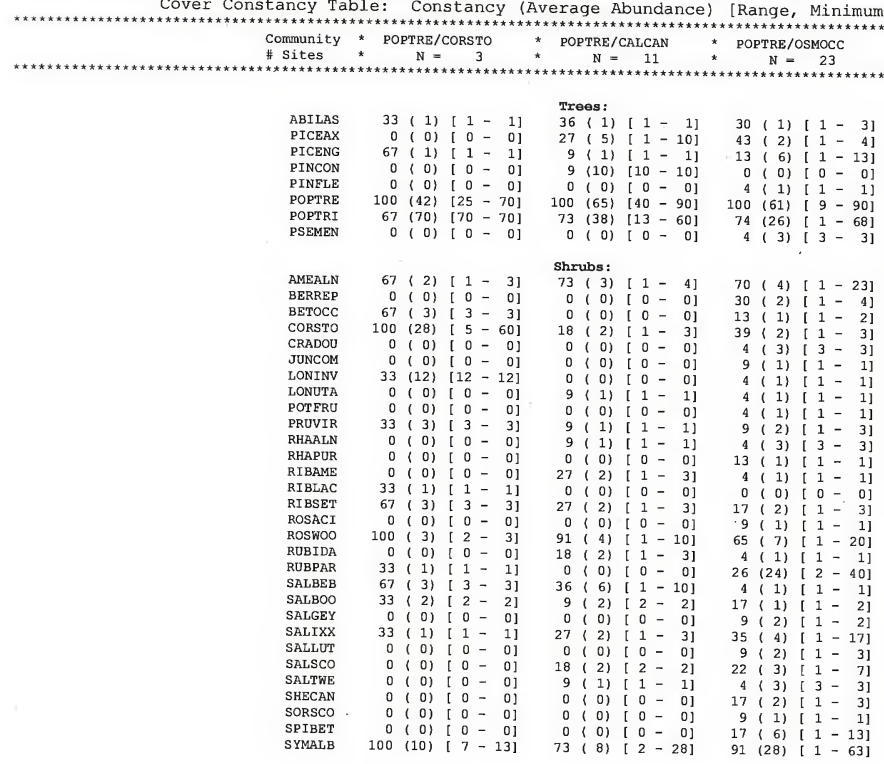


APPENDIX B. BLACKEEET INDIAN RESERVATION TREMBLING ASPEN-BLACK COTTONWOOD COMMUNITY TYPES: Cover Constancy Table: Constancy (Average Abundance) [Range, Minimum - Maximum]

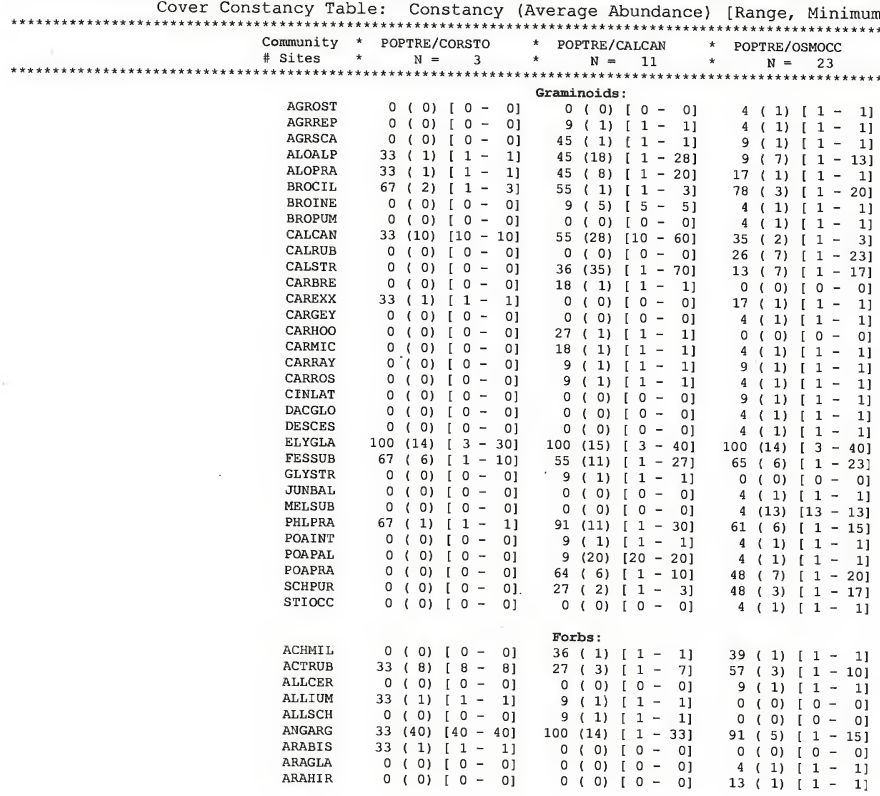



APPENDIX B. BLACKFEET INDIAN RESERVATION TREMBLING ASPEN-BLACK COTTONWOOD COMMUNITY TYPES: Cover Constancy Table: Constancy (Average Abundance) [Range, Minimum - Maximum]

\begin{tabular}{|c|c|c|c|c|c|c|c|c|c|c|c|c|c|c|c|}
\hline \multirow{46}{*}{ 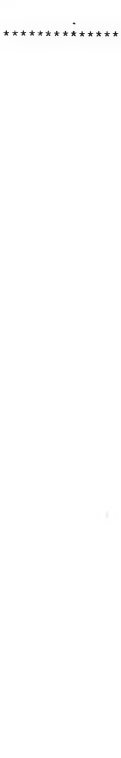 } & \multirow{2}{*}{ 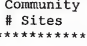 } & \multirow{2}{*}{\multicolumn{4}{|c|}{$\begin{array}{ccc}\star & \text { POPTRE } \\
\star & \mathrm{N}= & 3\end{array}$}} & & \multirow{2}{*}{$\begin{array}{l}\star \\
* \\
* \star \star\end{array}$} & \multirow{2}{*}{\multicolumn{3}{|c|}{$\begin{array}{l}\text { POPTRE/CALCAN } \\
\qquad \mathrm{N}=11\end{array}$}} & & \multicolumn{4}{|c|}{ * POPTRE/OSMOCC } \\
\hline & & & & & & & & & & & & & $\mathrm{N}=$ & & 23 \\
\hline & and & $x * \pi * \pi$ & $x \times x \leqslant x$ & $* \star * \pi$ & $\star \star \star$ & 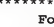 & 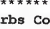 & Contin & $\begin{array}{l}\star \star \star \star \star \\
\text { ued: }\end{array}$ & & & & & & \\
\hline & ARCMIN & 0 & & & & -01 & 0 & $(0)$ & 10 & $0-$ & 0] & 4 & $(2)$ & [ 2 & $2-$ \\
\hline & ARELAT & 0 & $(0)$ & 10 & 0 & - 01 & 0 & $(0)$ & [ 0 & $0-$ & 0] & 4 & (1) & 1 & $1-1]$ \\
\hline & ARNCHA & 0 & $(0)$ & [ & 0 & -01 & 82 & $(2)$ & [ 1 & $1-$ & 4] & 22 & ( 1$)$ & [ 1 & $1-1]$ \\
\hline & ASTCON & 33 & (1) & [ & 1 & $-1]$ & 0 & $(0)$ & {$[0$} & $0-$ & . 0$]$ & 9 & (1) & I 1 & $1-1]$ \\
\hline & ASTENG & 33 & ( 1$)$ & [ & 1 & $-1]$ & 27 & $(1)$ & [ 1 & $1-$ & 2] & 30 & $(2)$ & [ 1 & $1-4]$ \\
\hline & ASTFOL & 67 & $(6)$ & [ 1 & 1 & $-10]$ & 36 & ( 4) & [ 1 & $1-$ & 13] & 35 & $(2)$ & I 1 & $1-10]$ \\
\hline & ASTLAE & 0 & $(0)$ & 10 & 0 & -01 & 73 & $(5)$ & [ 2 & $2-$ & $13]$ & 61 & (3) & [ 1 & $1-7]$ \\
\hline & CAMQUA & 33 & ( 1$)$ & I 1 & 1. & $-1]$ & 36 & $(2)$ & [ 1 & $1-$ & 4] & 17 & (1) & [ 1 & $1-1]$ \\
\hline & CAMROT & 67 & ( 1$)$ & [ 1 & 1 & -11 & 27 & ( 1$)$ & [ 1 & $1-$ & 1] & 17 & ( 1$)$ & [ 1 & $1-1]$ \\
\hline & CASLUT & 0 & $(0)$ & [ 0 & 0 & - 01 & 18 & $(1)$ & [ 1 & $1-$ & 1] & 9 & $(2)$ & [ 1 & {$[-3]$} \\
\hline & CASMIN & 0 & $(0)$ & I & 0 & - 01 & 9 & (1) & [ 1 & $1-$ & 1] & 22 & ( 1$)$ & [ 1 & {$[-1]$} \\
\hline & CASRHE & 0 & $(0)$ & 10 & 0 & - 01 & 9 & ( 1$)$ & I 1 & $1-$ & 1] & 0 & $(0)$ & i 0 & $-0]$ \\
\hline & CASTIL & 33 & ( 1$)$ & {$[1$} & 1 & $-1]$ & 9 & ( 1$)$ & [ 1 & $1-$ & 1] & 0 & $(0)$ & 0 & $-0]$ \\
\hline & CERAST & 0 & $(0)$ & 10 & 0 & - 01 & 0 & $(0)$ & 10 & - & 0] & 4 & ( 1$)$ & [ 1 & {$[-1]$} \\
\hline & CIRARV & 33 & ( 1$)$ & [ ] & 1 & $-1]$ & 0 & $(0)$ & [ 0 & - & 0] & 0 & $(0)$ & {$[0$} & $-0]$ \\
\hline & CIRHOO & 0 & $(0)$ & 10 & 0 & -01 & 0 & $(0)$ & 10 & - & 0] & 4 & ( 1$)$ & 1 & {$[-1]$} \\
\hline & CIRSCA & 0 & $(0)$ & {$[0$} & 0 & $-\quad 0]$ & 0 & $(0)$ & 10 & - & 0] & 4 & ( 1$)$ & [ 1 & {$\left[\begin{array}{l}-1] \\
0\end{array}\right.$} \\
\hline & CIRSIU & 0 & $(0)$ & 10 & 0 & $-0]$ & 9 & (1) & [ 1 & $1-$ & 1] & 0 & $(0)$ & {$[0$} & - 0 ] \\
\hline & CIRVUL. & 0 & $(0)$ & [ 0 & 0 & $-\quad 0]$ & 0 & $(0)$ & {$[0$} & - & 0] & 4 & $(1)$ & [ 1 & $-1]$ \\
\hline & DESPIN & 0 & $(0)$ & [ 0 & 0 & $-\quad 0]$ & 0 & $(0)$ & 10 & - & 0] & 9 & $(1)$ & [ 1 & $-1]$ \\
\hline & DISHOO & 33 & (4) & [ 4 & 4 & $-4]$ & 9 & $(10)$ & {$[10$} & - & $10]$ & 35 & $(12)$ & [ 1 ] & -301 \\
\hline & DISTRA & 33 & (1) & [ 1 & 1 & $-1]$ & 0 & $(0)$ & {$[0$} & - & 0] & 22 & $(1)$ & [ 1 & -11 \\
\hline & EPIANG & 33 & ( 1$)$ & [ 1 & 1 & $-1]$ & 18 & ( 1$)$ & [ 1 & - & 1] & 17 & ( 3$)$ & [ 1 & -71 \\
\hline & EPICIL & 0 & $(0)$ & [ 0 & & $-\quad 0]$ & 64 & $(1)$ & [ 1 & - & 2] & 9 & $(1)$ & [ 1 & $-1]$ \\
\hline & EPILOB & 33 & ( 1$)$ & [ 1 & 1 & $-1]$ & 9 & ( 1$)$ & [ 1 & - & 1] & 0 & $(0)$ & 10 & $-0]$ \\
\hline & ERYGRA & 0 & $(0)$ & [ 0 & 0 & $-\quad 0]$ & 18 & $(8)$ & [ 3 & - & 13] & 35 & $(16)$ & [ 1 & $-30]$ \\
\hline & FRAVES & 0 & $(0)$ & [ 0 & & $-\quad 0]$ & 9 & ( 1$)$ & [ 1 & - & 1] & 4 & (1) & [ 1 & $-1]$ \\
\hline & FRAVIR & 67 & $(1)$ & I 1 & & - 1$]$ & 91 & $(8)$ & [ 1 & - & $20]$ & 78. & $(5)$ & [ 1 & $-17]$ \\
\hline & GALBOR & 33 & $(3)$ & {$[3$} & 3 & - $\quad 3]$ & 82 & (2) & [ 1 & - & 4] & 61 & ( 2) & [ 1 & $-7]$ \\
\hline & GALTET & 0 & $(0)$ & {$[0$} & 0 & $-\quad 0]$ & 9 & ( 1$)$ & [ 1 & - & 1] & 0 & $(0)$ & {$[0$} & $\left.\begin{array}{ll}- & 0\end{array}\right]$ \\
\hline & GALTRI & 33 & $(3)$ & [ 3 & 3 & - 3] & 36 & (1) & [ 1 & - & 1] & 30 & $(5)$ & [ 1 & $-13]$ \\
\hline & GERRIC & 100 & $(7)$ & [ 3 & 3 & $-10]$ & 100 & (3) & [ 1 & - & 101 & 87 & (4) & [ 1 & - 17] \\
\hline & GERVIS & 33 & (1) & [ 1 & & $-\quad 1]$ & 0 & $(0)$ & 10 & - & 0] & 9 & ( 3$)$ & [ 1 & $-5]$ \\
\hline & GEUMAC & 67 & ( 3$)$ & 13 & 3 & $-\quad 31$ & 91 & (5) & [ 1 & - & 13] & 74 & (3) & I 1 & -201 \\
\hline & HABDI I & 33 & (1) & [ 1 & $1-$ & $-\quad 1]$ & 9 & ( 1$)$ & [ 1 & - & $1]$ & 0 & $(0)$ & 10 & $\begin{array}{ll}- & 0\end{array}$ \\
\hline & HABSAC & 0 & $(0)$ & {$[0$} & 0 & $-\quad 0]$ & 0 & $(0)$ & {$[0$} & - & 0] & 4 & (1) & [ 1 & $-1]$ \\
\hline & HABUNA & 0 & $(0)$ & 10 & 0 & - 0$]$ & 9 & ( 1$)$ & [ 1 & - & 1] & 4 & (1) & [ 1 & $-1]$ \\
\hline & HACFLO & 33 & (1) & [ 1 & 1 & $-\quad 1]$ & 27 & ( 1$)$ & [ 1 & - & 1] & 43 & (1) & [ 1 & $-1]$ \\
\hline & HERLAN & 67 & (23) & {$[20$} & - & $-25]$ & 55 & $(8)$ & [ 1 & - & 40] & 61 & (17) & [ 1 & $-60]$ \\
\hline & IRIMIS & 0 & $(0)$ & 10 & 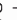 & $-\quad 0]$ & 0 & $(0)$ & [ 0 & - & 0] & 4 & (1) & [ 1 & - 1] \\
\hline & LATOCH & 0 & $(0)$ & 10 & - & $-\quad 01$ & 64 & ( 1$)$ & [ 1 & - & 3] & 48 & $(2)$ & [ 1 & - 3] \\
\hline & LOMDIS & 0 & $(0)$ & {$[0$} & - & -01 & 01 & $(0)$ & {$[0$} & - & 0] & 4 & (3) & {$[3$} & - 3] \\
\hline & MEDSAT & 0 & $(0)$ & 10 & $0-$ & - $\quad 01$ & 01 & $(0)$ & {$[0$} & - & 0] & 4 & (1) & [ 1 & $-1]$ \\
\hline
\end{tabular}



APPENDIX B.BLACKEEET INDIAN RESERVATION TREMBLING ASPEN-BLACK COTTONWOOD COMMUNITY TYPES: Cover Constancy Table: Constancy (Average Abundance) [Range, Minimum - Maximum]

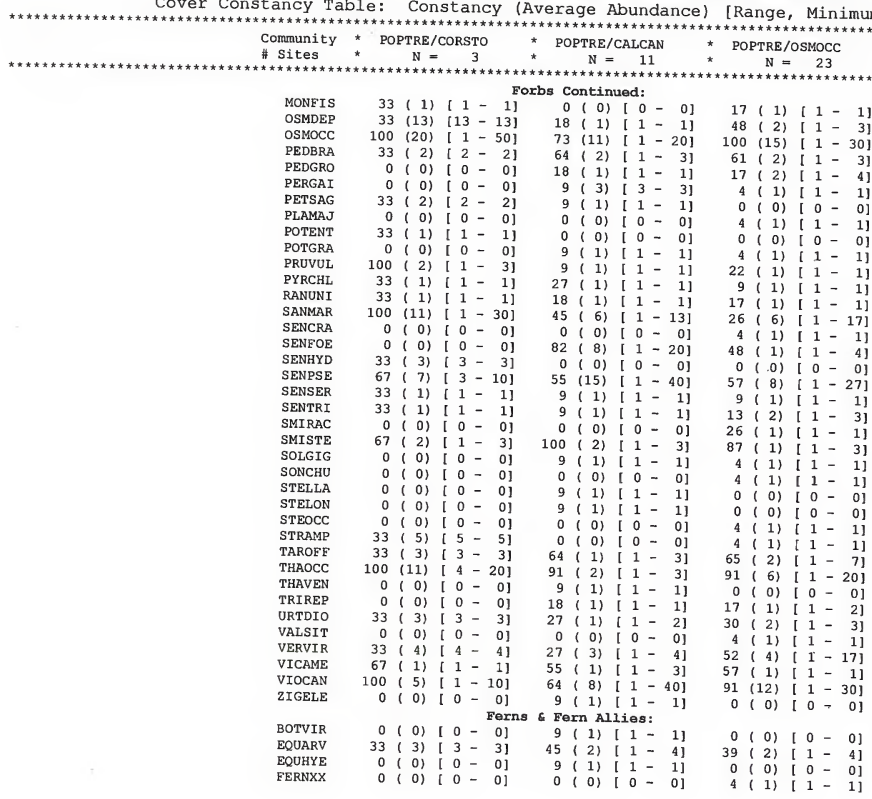



APPENDIX C. Scatterplots of stem density by 2 inch size classes without regard to species. (Separate plots for live and dead; plots arranged in ascending order of stand number, five stands per scatterplot; see Appendix D for breakdown of stem density by species, size classes, and live versus dead)

\section{Live Stem Desity; Stands 17, 18, 19, 20, \& 21}

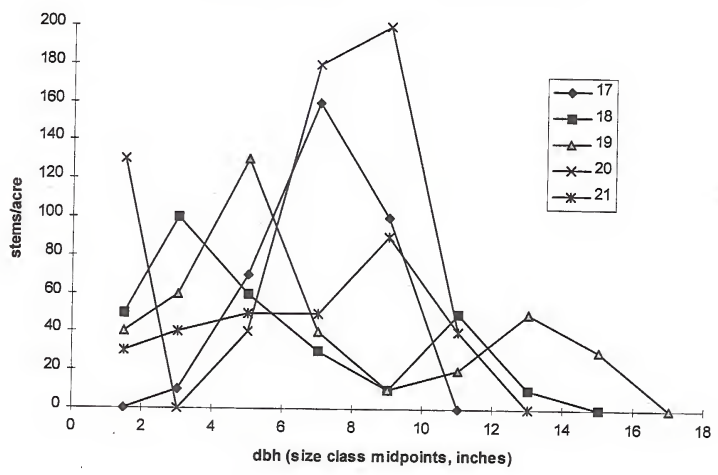

Dead Stem Density: Stands 17, 18, 19, 20, 21

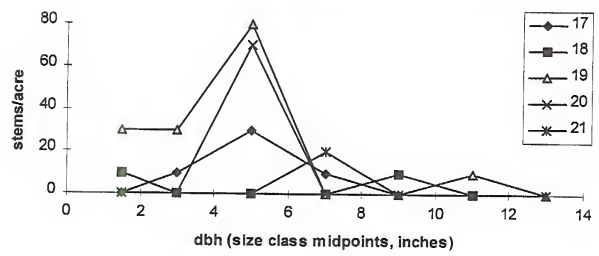





\section{APPENDIX C (Continued)}

Live Stem Density; Stands 23, 24, 25, 26, 27

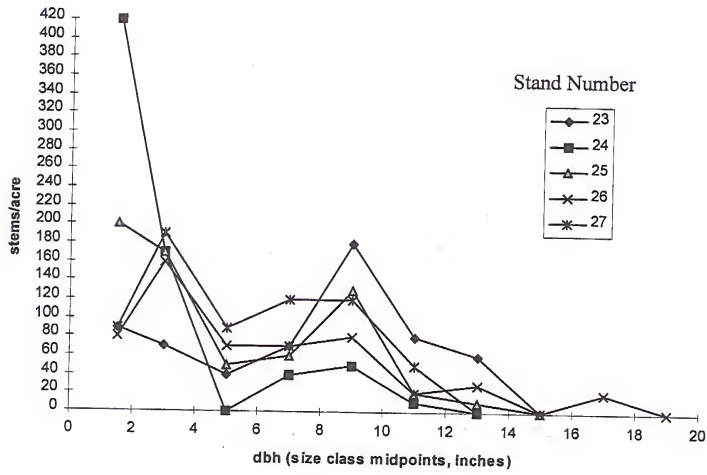

Live Stem Density; Stands 23, 24, 25, 26, 27

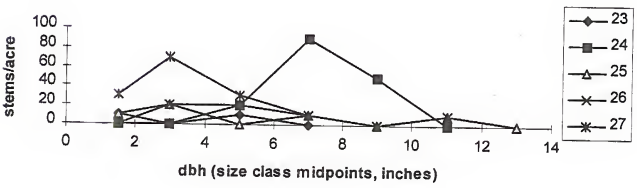



Live Stem Density; Stands 28, 29, 30, 31, 32
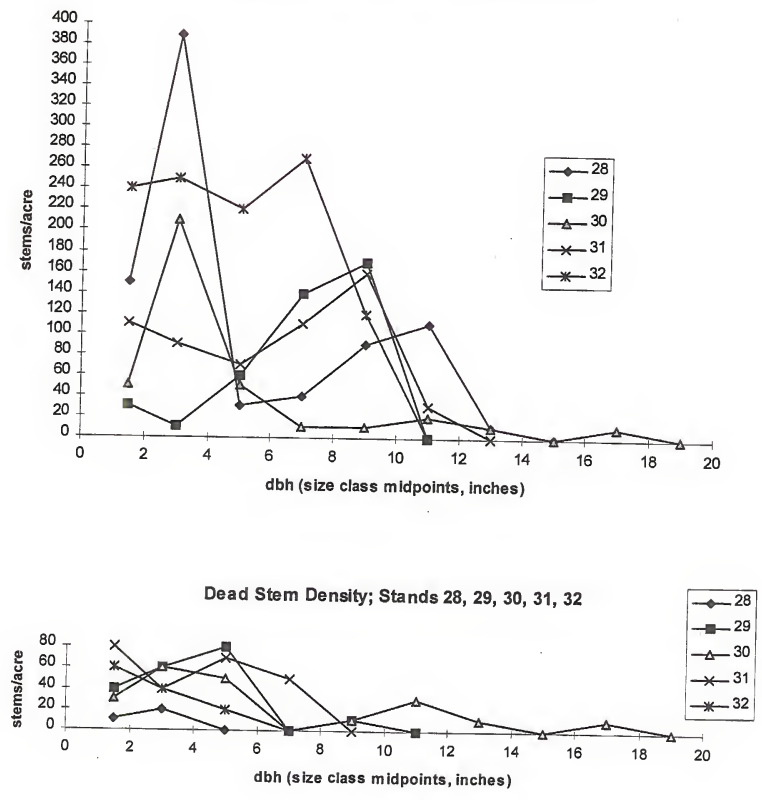



\section{APPENDIX C (Continued)}

Live Stem Density; Stand 33, 34, 35, 36, 37

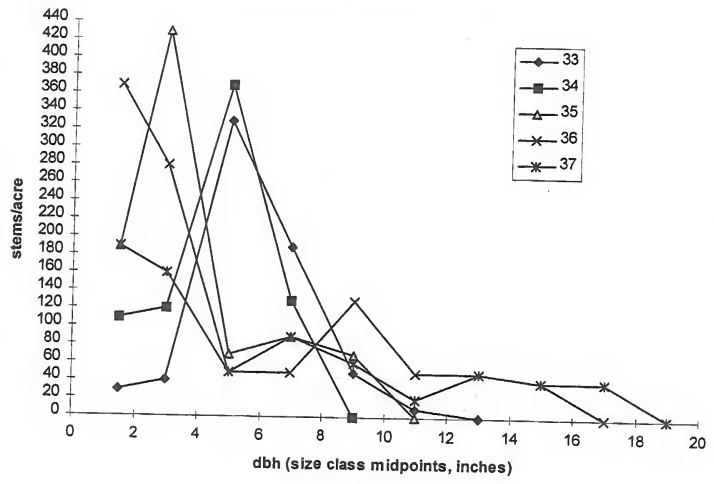

Dead Stem Density; Stands 33, 34, 35, 36, 37

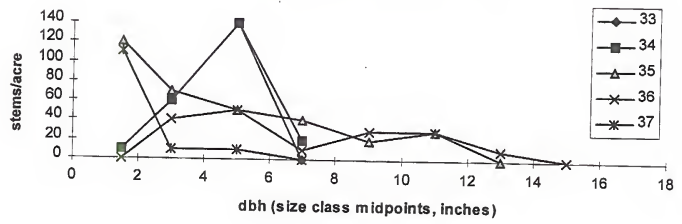




\section{APPENDIX C (Continued)}

Live Stem Density; Stands 38, 39, 40, 41, 42

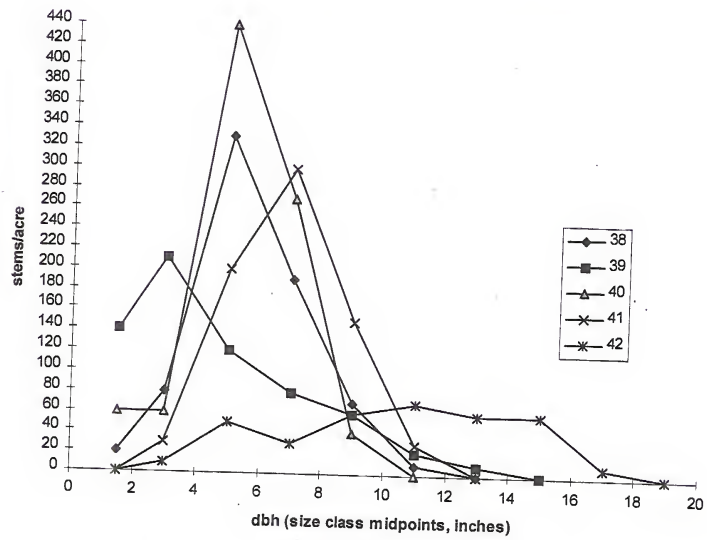

Dead Stem Density; Stands 38, 39, 40, 41, 42

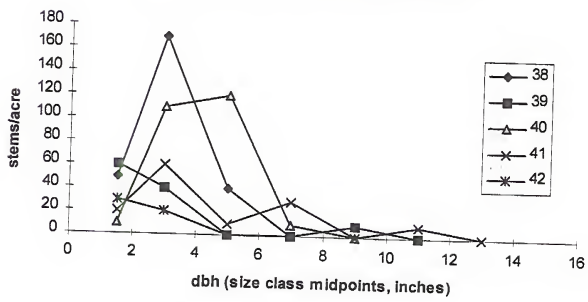





\section{APPENDIX C (Continued)}
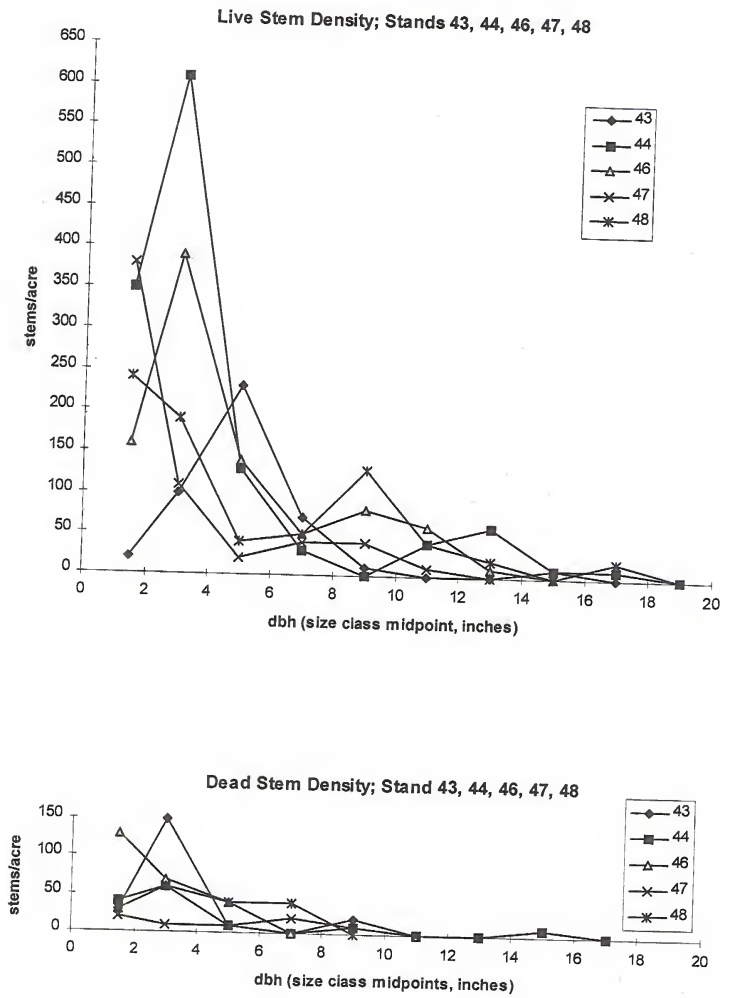



\section{APPENDIX C (Continued)}

\section{Live Stem Density; Stands 50, 51}

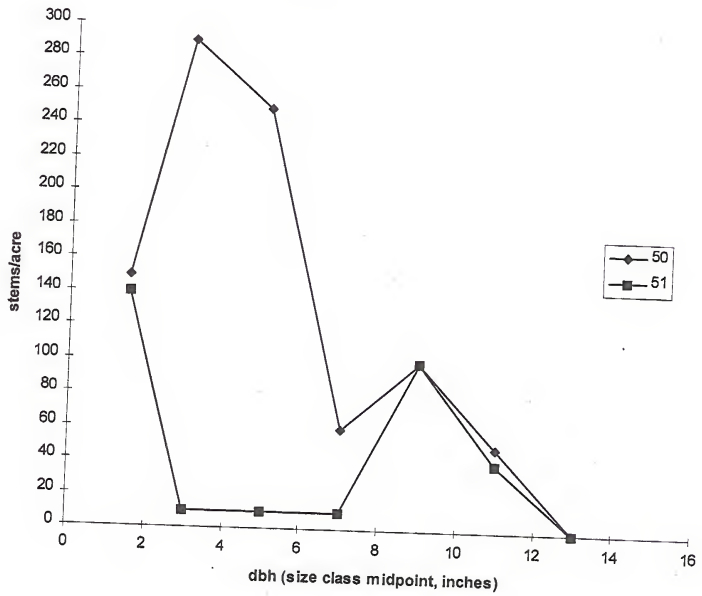

Dead Stem Density; Stands 50, 51

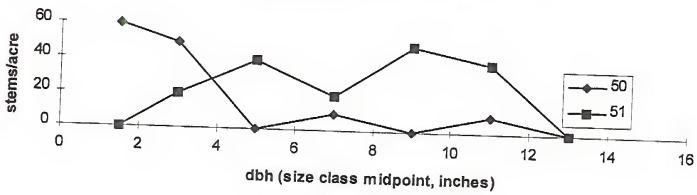


APPENDIX D (continued) TREMBLING ASPEN-BLACK COTTONWOOD TREE POPULATIONS BY SITE AND SPECIES DIAMETER CLASSF DIAMETER CLASSES BY 1 AND 2 INCH INCREMENTS (CELL VALUES, NUMBER OF TREES PER ACRE)

\begin{tabular}{|c|c|c|c|c|c|c|c|c|c|c|c|c|c|c|c|c|c|c|c|c|c|c|c|c|c|c|c|c|}
\hline 1 & 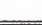 & $1-2$ & 1 & & $>2-4$ & I & & $4-6$ & 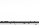 & & $>6-8$ & & & $8-10$ & , & $y$ & $10-12$ & & $>$ & $12-14$ & 1 & $y$ & $14-16$ & & & & 16 & \\
\hline TITE & $\mathrm{TA}^{\prime}$ & $\mathrm{BC}^{2}$ & $\mathrm{OT}^{3}$ & TA & $\mathrm{BC}$ & OT & TA & $\mathrm{BC}$ & OT & $\mathrm{TA}$ & $\mathrm{BC}$ & OT & $\mathrm{TA}$ & $\mathrm{BC}$ & OT & $\mathrm{TA}$ & $B C$ & OT & $\mathrm{TA}$ & $\mathrm{BC}$ & OT & TA & $\mathrm{BC}$ & OT & $\mathrm{T}$ & & $\mathrm{BC}$ & OT \\
\hline $038 \mathrm{~L}^{\circ}$ & 20 & & & 80 & & & 330 & & & 190 & & & 70 & & & 10 & & & 0 & & & & & & & & & \\
\hline 038D & 50 & & & 170 & & & 40 & & & 0 & & & & & & & & & & & & & & & & & & \\
\hline 039L & 140 & & & 210 & & & 120 & & & 80 & & & 60 & & & 20 & & & 10 & & & & & & & & & \\
\hline 039D & 60 & & & 40 & & & 0 & & & 0 & & & 10 & & & 0 & & & & & & & & & & & & \\
\hline $040 \mathrm{~L}$ & 50 & 0 & 10 & 60 & 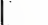 & & 440 & & & 270 & & & 40 & & & 0 & & & & & & & & & & & & \\
\hline 040D & 10 & & & 110 & & & 120 & & & 10 & & & 0 & & & & & & & & & & & & & & & \\
\hline $041 \mathrm{~L}$ & 0 & & & 30 & & & 190 & 10 & & 260 & 40 & & 140 & 10 & & 30 & & & 0 & & & & & & & & & \\
\hline $041 \mathrm{D}$ & 20 & 0 & & 60 & 0 & & 10 & 0 & & 30 & 0 & & 0 & 0 & & 0 & 10 & & & & & & & & & & & \\
\hline $042 \mathrm{~L}$ & 0 & & & 10 & & & 50 & & & 30 & & & so & 0 & 10 & 70 & & & 50 & 0 & 10 & 60 & & & & 0 & & \\
\hline $042 \mathrm{D}$ & 30 & & & 20 & & & 0 & & & & & & & & & & & & & & & & & & & & & \\
\hline $043 \mathrm{~L}$ & 20 & & & 100 & & & 230 & & & 30 & 40 & & 0 & 10 & & 0 & & & 0 & & & 0 & 10 & & & & & \\
\hline 043D & 10 & 20 & & 140 & 10 & & 10 & 0 & & 0 & & & 0 & 20 & & & & & & & & & & & & & & \\
\hline $044 \mathrm{~L}$ & 280 & 70 & & 510 & 100 & & 0 & 130 & & 0 & 30 & & 0 & 0 & & 0 & 40 & & 0 & 60 & & 0 & 10 & & & 0 & 10 & \\
\hline $044 \mathrm{D}$ & 40 & 0 & & 0 & 60 & & 0 & 10 & & 0 & 0 & & 0 & 10 & & 0 & 0 & & 0 & 0 & & 0 & 10 & & & & & \\
\hline $045 \mathrm{~L}$ & $\mathrm{Nl}^{4}$ & & & & & & & & & & & & & & & & & & & & & & & & & & & \\
\hline 045D & $\mathrm{N} 1$ & & & & & & & & & & & & & & & & & & & & & & & & & & & \\
\hline $046 \mathrm{~L}$ & 110 & 50 & & 330 & 60 & & 90 & 40 & 10 & 50 & 0 & & 70 & 10 & & 60 & & & 10 & & & & & & & & & \\
\hline $046 \mathrm{D}$ & I10 & 20 & & 70 & & & 40 & 0 & & 0 & & & 10 & & & & & & & & & . & & & & & & \\
\hline $047 \mathrm{~L}$ & 180 & 200 & & 60 & 40 & 10 & 20 & & & 40 & & & 40 & & & 10 & & & & & & & & & & & & \\
\hline 047D & 0 & 20 & & 0 & 10 & & 0 & 10 & & 20 & 0 & & 0 & 10 & & & & & & & & & & & & & & \\
\hline
\end{tabular}

A = trembling aspen (Populus tremuloides)

C = black cottonwood (Populus trichocarpa)

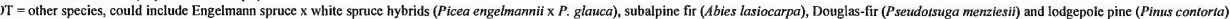

$\mathrm{I}=$ not inventoried 

APPENDIX D. TREMBLING ASPEN-BLACK COTTONWOOD TREE POPULATIONS BY SITE AND SPECIES DIAMETER CLASSES

DIAMETER CLASSES BY 1 AND 2 INCH INCREMENTS (CELL VALUES, NUMBER TREES PER ACRE)

\begin{tabular}{|c|c|c|c|c|c|c|c|c|c|c|c|c|c|c|c|c|c|c|c|c|c|c|c|c|c|c|c|}
\hline SITE $I$ & & $>1.2$ & 1 & & $2-4$ & 1 & & $4-6$ & 1 & & $>6-8$ & 1 & & $3-10$ & 1 & $>1$ & $10-12$ & 1 & $>1$ & $2-14$ & 1 & & $14-16$ & 1 & & 16 & \\
\hline $\begin{array}{l}\text { SIIE } \\
\text { No }\end{array}$ & $\mathrm{IA}^{\prime}$ & $\mathrm{BC}^{2}$ & $\mathrm{OT}^{*}$ & $T A$ & $\mathrm{BC}$ & OT & TA & $B C$ & OT & $\mathrm{TA}$ & $\mathrm{BC}$ & OT & $\overline{T A}$ & BC & OT & TA & $\mathrm{BC}$ & OT & $\mathrm{TA}$ & BC & or & $\mathrm{TA}$ & $\mathrm{BC}$ & OT & $\mathrm{TA}$ & $\overline{B C}$ & 01 \\
\hline $017 \mathrm{~L}^{\circ}$ & 0 & & & 10 & & & 70 & & & 160 & & & 100 & & & 0 & & & & & & & & & & & \\
\hline 0170 & 0 & & & 10 & & & 30 & & & 10 & & & 0 & & & 0 & & & & & & & & & & & \\
\hline $018 \mathrm{~L}$ & 50 & & & 100 & & & 60 & & & 30 & & & 10 & & & 50 & & & 10 & & & & & & & & \\
\hline 01815 & 10 & & & 0 & & & 0 & & & 0 & & & 10 & & & 0 & & & & & & & & & & & \\
\hline o19L. & 0 & 40 & & 30 & 30 & & 100 & 30 & & 40 & 0 & & 10 & 0 & & 0 & 20 & & 0 & 50 & & 10 & 20 & & & & \\
\hline 019D & 0 & 30 & & 10 & 20 & & 80 & 0 & & 0 & 0 & & 0 & 0 & & 0 & 10 & & 0 & 0 & & & & & & & \\
\hline 0201. & 130 & & & 0 & & & 40 & & & 180 & & & 200 & & & 40 & & & 0 & & & & & & & & \\
\hline $020 \mathrm{D}$ & 0 & & & 0 & & & 70 & & & 0 & & & 0 & & & 0 & & & & & & & & & & & \\
\hline 021L. & 30 & & & 40 & & & so & & & 50 & & & 90 & & & 40 & & & 0 & & & & & & & & \\
\hline U210 & 0 & & & 0 & & & 0 & & & 20 & & & 0 & & & 0 & & & & & & & & & & & \\
\hline 0221. & $\mathrm{Ni}^{\circ}$ & & & & & & & & & & & & & & & & & & & & & & & & & & \\
\hline 0220 & $\mathrm{NI}$ & & & & & & $\cdot$ & & & & & & & & & & & & & & & & & & & & \\
\hline v231. & 70 & 20 & & so & 20 & & 30 & 10 & & 30 & 40 & & 90 & 90 & & 40 & 40 & & 40 & 20 & & 0 & 0 & & & & \\
\hline 0230 & 0 & 10 & & 0 & 0 & & 0 & 10 & & 0 & 0 & & & & & & & & & & & & & & & & \\
\hline 0241. & 420 & & & 170 & & & 0 & & & 40 & & & 50 & & & 10 & 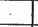 & & & & & & & & & & \\
\hline 0240 & 0 & & & 0 & & & 20 & & & 90 & & & 50 & & & 0 & & & & & & & & & & & \\
\hline 0231 & 160 & 40 & & 70 & 100 & & 0 & so & & 20 & 40 & & 80 & 30 & & 20 & 0 & & 10 & 0 & & 0 & 0 & & & & \\
\hline 0251) & 10 & 0 & & 0 & 20 & & 0 & 0 & & 0 & 10 & & 0 & 0 & & 10 & 0 & & 0 & 0 & & & & & & & \\
\hline 0261. & 80 & 0 & & 80 & 80 & & 20 & 50 & & 10 & 60 & & so & 30 & & 20 & 0 & & 0 & 30 & & 0 & 0 & & 0 & 20 & \\
\hline $02(1)$ & 0 & 0 & & 0 & 20 & & 0 & 20 & & 0 & 10 & & 0 & 0 & & & & & & & & & & & & & \\
\hline 0271 & 20 & 70 & & 100 & 90 & & 30 & 60 & & 0 & 120 & & 110 & 10 & & 50 & 0 & & & & & & & & & & \\
\hline 0270 & 10 & 20 & & 10 & 60 & & 0 & 30 & & 0 & 10 & & 0 & 0 & & 10 & 0 & & & & & & & & & & \\
\hline
\end{tabular}

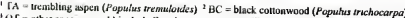

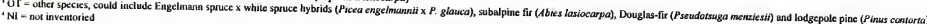



APPENDIX D (continued). TREMBLING ASPEN-BLACK COTTONWOOD TREE POPULATIONS BY SITE AND SPECIES DIAMETER CLASSES

\begin{tabular}{|c|c|c|c|c|c|c|c|c|c|c|c|c|c|c|c|c|c|c|c|c|c|c|c|c|c|c|c|}
\hline 1 & & $1-2$ & 1 & & $2-4$ & 1 & & $4-6$ & 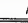 & & $>6-8$ & 1 & $>$ & $8-10$ & 1 & $>$ & $0-12$ & 1 & $\geq$ & $2-14$ & I & $>$ & $14-16$ & 1 & & 16 & 1 \\
\hline \begin{tabular}{|l}
$S I I E$ \\
No \\
\end{tabular} & $\mathrm{TA}^{\mathrm{i}}$ & $B C^{*}$ & $\mathrm{Or}^{3}$ & TA & $\mathrm{BC}$ & OT & TA & $\mathrm{BC}$ & OT & TA & $\mathrm{BC}$ & or & $\mathrm{TA}$ & $\mathrm{BC}$ & OT & $T \mathrm{TA}$ & $\mathrm{BC}$ & OT & $\mathrm{TA}$ & $\mathrm{BC}$ & OT & TA & $\overline{B C}$ & OT & TA & BC & or \\
\hline $281^{\circ}$ & 150) & & & 390 & & & 30 & & & 40 & & & 90 & & & 110 & & & 10 & & & & & & & & \\
\hline (1) $\left.2 x_{1}\right)$ & 10 & & & 20 & & & 0 & & & & & & & & & & & & & & & & & & & & \\
\hline 0291 & 10 & 20 & & 10 & & & 60 & & & 140 & & & 170 & & & 0 & & & & & & & & & & & \\
\hline 0291 & 40 & 0 & & 60 & & & 80 & & & 0 & & & 10 & & & 0 & & & & & & & & & & & \\
\hline 0301 & 50 & & & 210 & & & 50 & & & 10 & & & 10 & & & 20 & & & 10 & & & 0 & & & 0 & 10 & \\
\hline U30D & 30 & & & 60 & & & so & & & 0 & & & 10 & & & 30 & & & 10 & & & 0 & & & 10 & & \\
\hline 03HL & 110 & & & 90 & & & 70 & & & 110 & & & 160 & & & 30 & & & 0 & & & & & & & & \\
\hline 0310 & $y_{0}$ & & & 40 & & & 70 & & & so & & & 0 & & & & & & & & & & & & & & \\
\hline $632 \mathrm{~L}$ & 180 & 60 & & 210 & 40 & & 190 & 30 & & 260 & 10 & & 120 & & & & & & & & & & & & & & \\
\hline 0320 & 50 & 10 & & 40 & 0 & & 20 & 0 & & 0 & 0 & & & & & & & & & & & & & & & & \\
\hline 0331. & 10 & 20 & & 20 & 10 & 10 & 330 & 0 & & 190 & 0 & & 30 & 20 & & 0 & 10 & & & & & & & & & & \\
\hline 0330 & 10 & 0 & & 60 & 0 & & 140 & 0 & & & & & & & & & & & . & & & . & & & & & \\
\hline 03.1. & 110 & & & 120 & & & 370 & & & 130 & & & & & & & & & & & & & & & & & \\
\hline 0340 & 10 & & & 60 & & & 140 & & & 20 & & & & & & & & & & & & & & & & & \\
\hline 0351 & 190 & & & 430 & & & 70 & & & 90 & & & 70 & & & 0 & & & & & & & & & & & \\
\hline 035D & 120 & & & 70 & & & 50 & 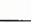 & & 40 & & & 20 & & & 30 & & & & & & & & & & & \\
\hline 0361 & 230 & 140 & & 210 & 70 & & 30 & 20 & & 10 & 40 & & 80 & 50 & & 10 & 40 & & 0 & 50 & & 0 & 40 & & & & \\
\hline $036 \mathrm{D}$ & 0 & 0 & & 10 & 30 & & 30 & 20 & & 0 & 10 & & 0 & 30 & & 0 & 30 & & 0 & 10 & & & & & & & \\
\hline 6371. & 100 & 70 & 10 & 120 & 40 & & 30 & 20 & & 70 & 20 & & 60 & 0 & & 10 & 10 & & 0 & 50 & & 0 & 40 & & 0 & 40 & \\
\hline $037 \mathrm{D}$ & 30 & 60 & & 10 & 0 & & 10 & 0 & & 0 & 0 & & & & & & & & & & & & & & & & \\
\hline
\end{tabular}

${ }^{1}[\mathrm{~A}-$ trembling aspen (Populus iremuloides)

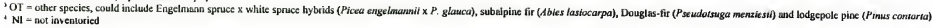


APPENDIX D (continued) TREMBLING ASPEN-BLACK COTTONWOOD TREE POPULATIONS BY SITE AND SPECIES DIAMETER CLASSES DIAMETER CLASSES BY 1 AND 2 INCH INCREMENTS (CELL VALUES, NUMBER OF TREES PER ACRE)

\begin{tabular}{|c|c|c|c|c|c|c|c|c|c|c|c|c|c|c|c|c|c|c|c|c|c|c|c|c|c|c|c|}
\hline 1 & & 81.2 & 1 & & $>2-4$ & 1 & & $>4-6$ & f & 1 & $>6-8$ & 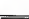 & & $8-10$ & 1 & & $10-12$ & 1 & & $12-14$ & 1 & & $14-16$ & 1 & & 16 & \\
\hline $\begin{array}{l}\text { SIIE } \\
\text { No } \\
\end{array}$ & $\mathrm{IA}^{\prime}$ & $\mathrm{BC}^{2}$ & $\mathrm{OI}^{\prime}$ & TA & $\mathrm{BC}$ & OT & $\mathrm{TA}$ & $\mathrm{BC}$ & OT & $\mathrm{TA}$ & $\mathrm{BC}$ & OT & $\mathrm{TA}$ & $\mathrm{BC}$ & OT & $\mathrm{TA}$ & $\mathrm{BC}$ & Oт & $\mathrm{TA}$ & $\mathrm{BC}$ & OT & TA & $\mathrm{BC}$ & OT & IA & $B C$ & or \\
\hline $038 \mathrm{~L}^{\circ}$ & 20 & & & 80 & & & 330 & & & 190 & & & 20 & & & 10 & & & 0 & & & & & & & & \\
\hline U381s & 50 & & & 170 & & & 40 & & & 0 & & & & & & & & & & & & & & & & & \\
\hline 1391 & $1 \neq 0$ & & & 210 & & & 120 & & & 80 & & & 60 & & & 20 & & & 10 & & & & & & & & \\
\hline $039 \mathrm{D}$ & 60 & & & 40 & & . & 0 & & & 0 & & & 10 & & & 0 & & & & & & & & & & & \\
\hline 040L & so & 0 & 10 & 60 & & & 440 & & & 270 & & & 40 & & & 0 & & & & & & & & & & & \\
\hline $040 \mathrm{D}$ & 10 & & & 110 & & & 120 & & & 10 & & & 0 & & & & & & & & & & & & & & \\
\hline $0+1 \mathrm{~L}$ & 0 & & & 30 & & & 190 & 10 & & 260 & 40 & & 140 & 10 & & 30 & & & 0 & & & & & & & & \\
\hline OAID & 20 & 0 & & 60 & 0 & & 10 & 0 & & 30 & 0 & & 0 & 0 & & 0 & 10 & & & & & & & & & & \\
\hline 0421 & 0 & & & 10 & & & 50 & & & 30 & & & so & 0 & 10 & 70 & & & 50 & 0 & 10 & 60 & & & 10 & & \\
\hline $\mathrm{OAN}_{20}$ & 30 & & & 20 & & & 0 & & & & & & & & & & & & & & & & & & & & \\
\hline $043 \mathrm{~L}$ & 20 & & & 100 & & & 230 & & & 30 & 40 & & 0 & 10 & & 0 & & & 0 & & & 0 & 10 & & & & \\
\hline $10+30$ & 10 & 20 & & 140 & 10 & & 10 & 0 & & 0 & & & 0 & 20 & & & & & & & & & & & & & \\
\hline vit1. & 280 & 70 & & 510 & 100 & & 0 & 130 & & 0 & 30 & & 0 & 0 & & 0 & 40 & & 0 & 60 & & 0 & 10 & & 0 & 10 & \\
\hline $0+410$ & to & 0 & & 0 & 60 & & 0 & 10 & & 0 & 0 & & 0 & 10 & & 0 & 0 & & 0 & 0 & & 0 & 10 & & & & \\
\hline $0+451$ & $\mathrm{NH}^{*}$ & & & & & & & & & & & & & & & & & & & & & & & & & & \\
\hline GASD & NI & & & & & & & & & & & & & & & & & & & & & & & & & & \\
\hline HOL & 110 & 50 & & 330 & 60 & & 90 & 40 & 10 & 50 & 0 & & 70 & 10 & & 60 & & & 10 & & & & & & & & \\
\hline (HED & 110 & 20 & & 70 & & & 40 & 0 & & 0 & & & 10 & & & & & & & & & & & & & & \\
\hline 0471. & 180 & 200 & & 60 & 40 & 10 & 20 & & & 40 & & & 40 & & & 10 & & & & & & & & & & & \\
\hline 0471$)$ & 0 & 20 & & 0 & 10 & & 0 & 10 & & 20 & 0 & & 0 & 10 & & & & & & & & & & & & & \\
\hline
\end{tabular}

IA $=$ tembling aspen (Populus stremulondes)

BC = blach cotlunworod (Poputus trrehocarpa)

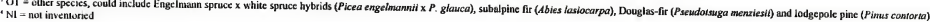


APPENDIX D (continued). TREMBLING ASPEN-BLACK COTTONWOOD TREE POPULATIONS BY SITE AND SPECIES DIAMETER CLASSES DIAMETER CLASSES BY 1 AND 2 INCH INCREMENTS (CELL VALUES, NUMBER OF TREES PER ACRE)

\begin{tabular}{|c|c|c|c|c|c|c|c|c|c|c|c|c|c|c|c|c|c|c|c|c|c|c|c|c|c|c|c|}
\hline 1 & & $>1-2$ & 1 & & $2-4$ & 1 & & $4-6$ & 1 & & $>6-8$ & 1 & & $8-10$ & 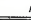 & & $10-12$ & 1 & & $12-14$ & 1 & & $14-16$ & 1 & & 16 & \\
\hline $\begin{array}{l}\text { Silt } \\
\text { No() }\end{array}$ & $1 A^{\prime}$ & $\mathrm{BC}^{2}$ & $\mathrm{OT}^{\prime}$ & $\mathrm{TA}$ & $\mathrm{BC}$ & OT & $\mathrm{TA}$ & $\mathrm{BC}$ & OT & TA & $\mathrm{BC}$ & OT & TA & $B C$ & от & TA & $\mathrm{BC}$ & or & $T A$ & $B C$ & OT & $\mathrm{TA}$ & $\mathrm{BC}$ & OT & $\mathrm{T}_{\mathrm{A}}$ & $B C$ & OI \\
\hline 0481 & 90 & 150 & & 40 & 150 & & 10 & 30 & & 30 & 20 & & 80 & 30 & & 10 & 30 & & & 20 & & 0 & 0 & & 0 & 20 & \\
\hline $0+812$ & 0 & 30 & & 0 & 60 & & 0 & 40 & & 30 & 10 & & 0 & 0 & & & & & & & & & & & & & \\
\hline 영. & $\mathrm{Na}^{-}$ & & & & & & & & & & & & & & & & & & & 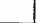 & & & & & & & \\
\hline 0490 & $\mathrm{~N} 1$ & & & & & & & & & & & & & & & & . & & & & & & & & & & \\
\hline osol. & 30 & 120 & & 100 & 180 & 10 & 70 & 160 & 20 & 0 & 60 & 0 & so & 50 & & 20 & 30 & & 0 & 0 & & & & & & & \\
\hline OSab & 20 & 40 & & 10 & 40 & & & & & 0 & 10 & & & & & 0 & 10 & & & & & & & & & & \\
\hline 05ИL & 70 & 70 & & 10 & 0 & & 0 & 10 & & 10 & 0 & & 100 & 0 & & 40 & 0 & & 0 & 0 & & & & & & & \\
\hline $050 \mathrm{D}$ & 0 & 0 & ${ }^{\circ}$ & 0 & 20 & & 0 & 40 & & 20 & 0 & & 50 & 0 & & 40 & 0 & & 0 & 0 & & & & & & & \\
\hline $052 \mathrm{~L}$ & $\mathrm{NI}$ & & & & & & & & & & & & & & & & & & & & & & & & & & \\
\hline $052 D$ & $\mathrm{NI}$ & & & & & & & & & & & & & & & & & & & & & & & & & & \\
\hline 0531. & $\mathrm{NI}$ & & & & & & & & & & & & & & & & & & & & & & & & & & \\
\hline (453) & $\mathrm{NI}$ & & & & & & & & & & & & & & & & & & & & & & & & & & \\
\hline & & & & & & & & & & & & & & & & & & & & & & & & & & & \\
\hline & & & & & & & & & & & & & & & & & & & & & & & & & & & \\
\hline & & & & & & & & & & & & & & & & & & & & & & & & & & & \\
\hline & & & & & & & & & & & & & & & & & & & & & & & & & & & \\
\hline & & & & & & & & & & & & & & & & & & & & & & & & & & & \\
\hline & & & & & & & & & & & & & & & & & & & & & & & & & & & \\
\hline & & & & & & & & & & & & & & & & & & & & & & & & & & & \\
\hline & & & & & & & & & & & & & & & & & & & & & & & & & & & \\
\hline
\end{tabular}

'L., line trices, D. dead irees

' I A - trembling aspen (Populus trevauloules)

"BC= = blach cottonu ood (Populus irwhociarpa)

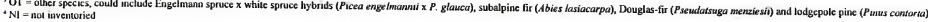



APPENDIX A.

BLACK-FEET INDIAN RESERVATION TREMBLING ASPEN-BLACK COTTONWOOD PLANT COMMUNITIES

Index for associating particular ECODATA plot numbers with their position in the Cover Synthesis (Stand) Table

1. POPTRE/CORSTO:

1. NHMTECBR96SC0017

2. NHMTECBR96SC0022

3. NHMTECBR96SC0019

2. POPTRE/CALCAN:

4. NHMTECBR96SC0039

7. NHMTECBR96SC0051

10. NHMTECBR $96 \mathrm{SC} 0023$

13. NHMTECBR96SC0025

5. NHMTECBR96SC0042

8. NHMTECBR96SC0046

6. NHMTECBR96SC0024

11. NHMTECBR96SC0036

9. NHMTECBR96SC0021

14. NHMTECBR96SC0048

12. NHMTECBR96SC0052

3. POPTRE/OSMOCC:

15. NHMTECBR96SC0035

18. NHMTECBR96SC0028

21. NHMTECBR96SC0029

24. NHMTECBR96SC0041

27. NHMTECBR96SC0033

30. NHMTECBR96SC0043

33. NHMTECBR96SC0047

16. NHMTECBR96SC0040

19. NHMTECBR96SC0038

17. NHMTECBR96SC0045

22. NHMTECBR96SC0053

20. NHMTECBR96SC0034

25. NHMTECBR96SC0030

23. NHMTECBR96SC0031

28. NHMTECBR96SC0027

26. NHMTECBR96SC0032

31. NHMTECBR96SC0044

29. NHMTECBR96SC0049

34. NHMTECBR96SC0037

35. NHMTECBR96SC0050

36. NHMTECBR96SC0018

32. NHMTECBR96SC0026

37. NHMTECBR96SC0020 

APPENDIX D (continued). TREMBLING ASPEN-BLACK COTTONWOOD TREE POPULATIONS BY SITE AND SPECIES DIAMETER CLASSI DIAMETER CLASSES BY 1 AND 2 INCH INCREMENTS (CELL VALUES, NUMBER OF TREES PER ACRE)

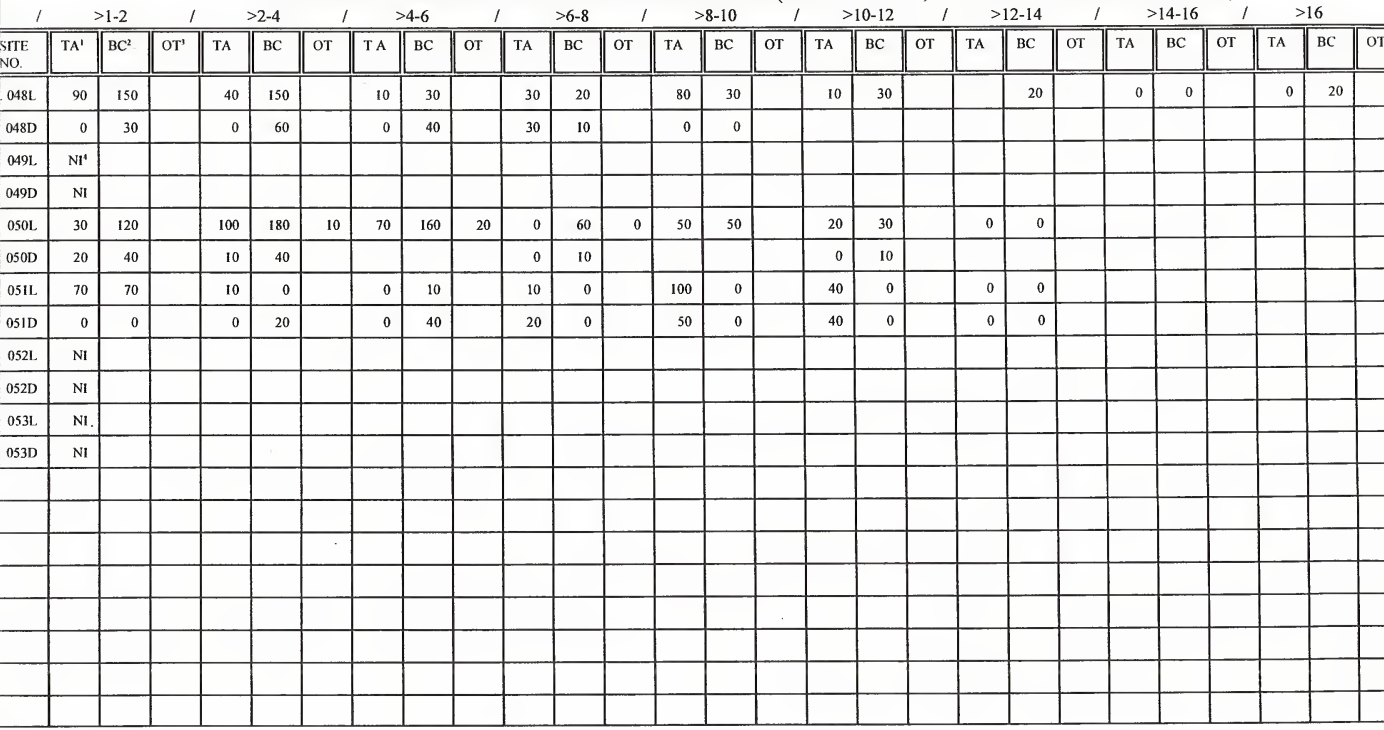

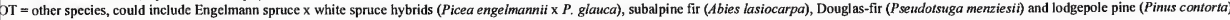

$\mathrm{NI}=$ not inventoried 

APPENDIX D. TREMBLING ASPEN-BLACK COTTONWOOD TREE POPULATIONS BY SITE AND SPECIES DIAMETER CLASSES DIAMETER CLASSES BY 1 AND 2 INCH INCREMENTS (CELL VALUES, NUMBER TREES PER ACRE)

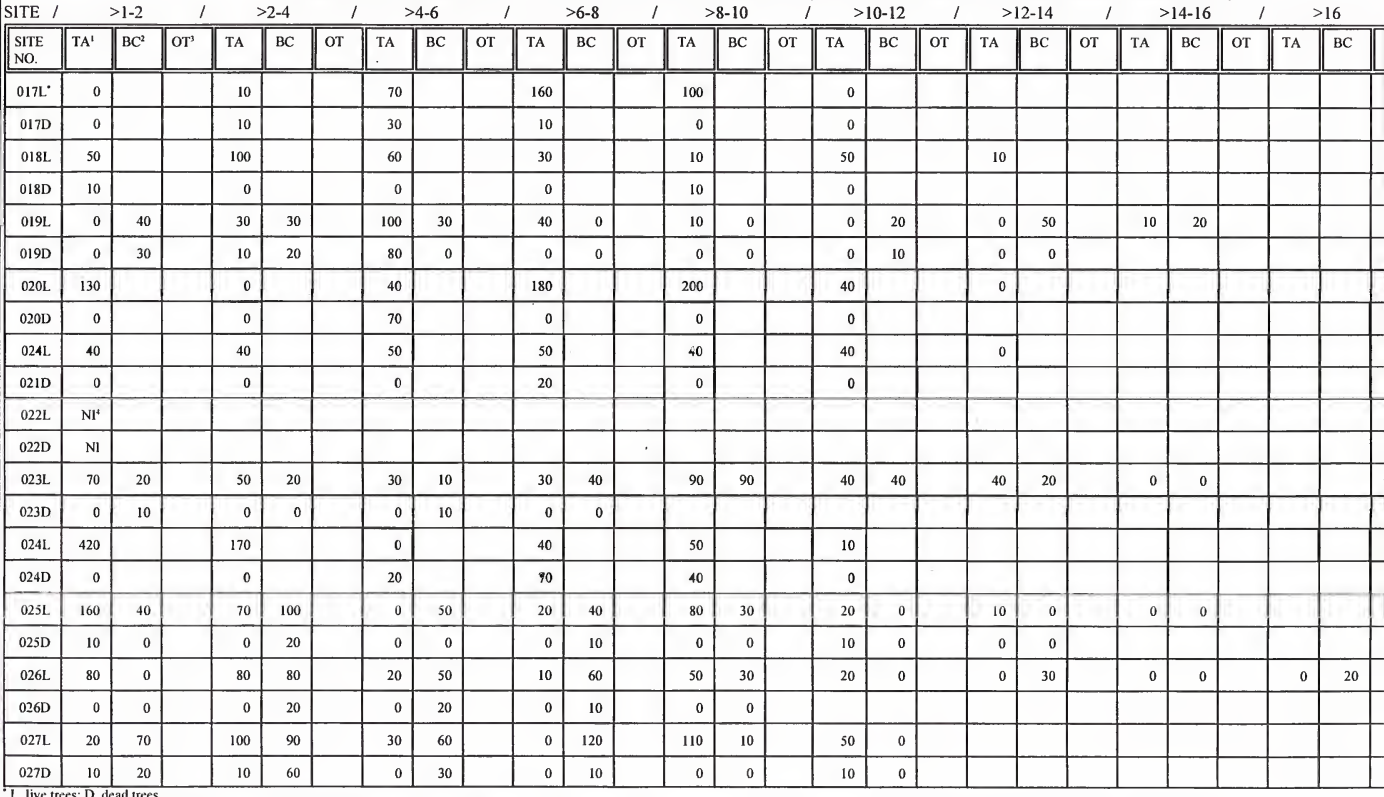

L, live trees; D, dead trees

${ }^{1} \mathrm{TA}=$ trembling aspen (Populus tremuloides) ${ }^{2} \mathrm{BC}=$ black cottonwood (Populus trichocarpa)

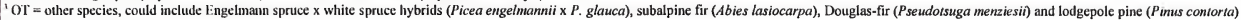

$4 \mathrm{NI}=$ not inventoried 
APPENDIX D. TREMBLING ASPEN-BLACK COTTONWOOD TREE POPULATIONS BY SITE AND SPECIES DIAMETER CLASSES DIAMETER CLASSES BY 1 AND 2 INCH INCREMENTS (CELL VALUES, NUMBER TREES PER ACRE)

\begin{tabular}{|c|c|c|c|c|c|c|c|c|c|c|c|c|c|c|c|c|c|c|c|c|c|c|c|c|c|c|c|}
\hline \multicolumn{2}{|c|}{ SITE } & $-1-2$ & \multicolumn{3}{|r|}{$>2-4$} & 1 & \multicolumn{2}{|c|}{$>4-6$} & \multicolumn{2}{|c|}{1} & $>6-8$ & 1 & \multicolumn{2}{|c|}{$>8-10$} & \multicolumn{3}{|c|}{$>10-12$} & 1 & \multicolumn{2}{|c|}{$>12-14$} & 1 & \multicolumn{2}{|c|}{$>14-16$} & \multicolumn{2}{|c|}{1} & \multicolumn{2}{|c|}{-16} \\
\hline \begin{tabular}{|l} 
SIII \\
vil
\end{tabular} & $1 \mathrm{~A}^{\prime}$ & $B C^{\circ}$ & $\mathrm{Or}^{\prime}$ & TA & $B C$ & or & $T A$ & $\mathrm{BC}$ & OT & TA & $\mathrm{BC}$ & OT & $T A$ & $\mathrm{BC}$ & OT & TA & $\mathrm{BC}$ & OT & TA & $B C$ & OT & TA & $B C$ & OT & $1 \mathrm{~A}$ & $B C$ & 111 \\
\hline יודים & 0 & & & 10 & & & 70 & & & 160 & & . & 100 & & & 0 & & & & & & & & & & & \\
\hline $01 \div 0$ & 0 & & & 10 & & & 30 & & & 10 & & & 0 & & & 0 & & & & & & & & & & & \\
\hline $018 \mathrm{~L}$ & 50 & & & 100 & & & 60 & & & 30 & & & 10 & & & 50 & & & 10 & & & & & & & & \\
\hline 0180 & 10 & & & 0 & & & 0 & & & 0 & & & 10 & & & 0 & & & & & & & & & & & \\
\hline 0191 & 0 & 40 & & 30 & 30 & & 100 & 30 & & 40 & 0 & & 10 & 0 & & 0 & 20 & & 0 & so & & 10 & 20 & & & & \\
\hline Юण & 0 & 30 & & 10 & 20 & & 80 & 0 & & 0 & 0 & & 0 & 0 & & 0 & 10 & & 0 & 0 & & & & & & & \\
\hline $0=24$ & 1.30 & & & 0 & & & 40 & & & 180 & & & 200 & & & 40 & & & 0 & & & & & & & & \\
\hline $0 \leq n$ & 0 & & & 0 & & & 70 & & & 0 & & & 0 & & & 0 & & & & & & & & & & & \\
\hline 1111 & 30 & & & 40 & & & 50 & & & 50 & & & 90 & & & 40 & & & 0 & & & & & & & & \\
\hline (1211) & 0 & & & 0 & & & 0 & & & 20 & & & 0 & & & 0 & & & & & & & & & & & \\
\hline 1921 & $\mathrm{NI}^{\circ}$ & . & & & & & & & & & & & & & & & & & & & & & & & & & \\
\hline $0: 20$ & $\mathrm{~N} 1$ & & & & & & & & & & & . & & & & & & & & & & & & & & & \\
\hline 021 & 70 & 20 & & so & 20 & & 30 & 10 & & 30 & 40 & & 90 & 90 & & 40 & 40 & & 40 & 20 & & 0 & 0 & & & & \\
\hline 0230 & 0 & 10 & & 0 & 0 & & 0 & 10 & & 0 & 0 & & & & & & & & & & & & & & & & \\
\hline $0: 41$ & 420 & & & 170 & & & 0 & & & 40 & & & 50 & & & 10 & & & & & & & & & & & \\
\hline 0241$)$ & 0 & & & 0 & & & 20 & & & 90 & & & so & & & 0 & & & & & & & & & & & \\
\hline 024 & 160 & 40 & & 70 & 100 & & 0 & 50 & & 20 & 40 & & 80 & 30 & & 20 & 0 & & 10 & 0 & & 0 & 0 & & & & \\
\hline $1025 \mathrm{D}$ & 10 & 0 & & 0 & 20 & & 0 & 0 & & 0 & 10 & & 0 & 0 & & 10 & 0 & & 0 & 0 & & & & & & & \\
\hline $10+1$ & 80 & 0 & & 80 & 80 & & 20 & 50 & & 10 & 60 & & 50 & 30 & & 20 & 0 & & 0 & 30 & & 0 & 0 & & 0 & 20 & \\
\hline$(126,1)$ & 0 & 0 & & 0 & 20 & & 0 & 20 & & 0 & 10 & & 0 & 0 & & & & & & & & & & & & & \\
\hline 0271 & 20 & 70 & & 100 & 90 & & 30 & 60 & & 0 & 120 & & 110 & 10 & & so & 0 & & & & & & & & & & \\
\hline 0271 & 10 & 20 & & 10 & 60 & & 0 & 30 & & 0 & 10 & & 0 & 0 & & 10 & 0 & & & & & & & & & & \\
\hline
\end{tabular}

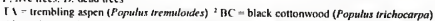

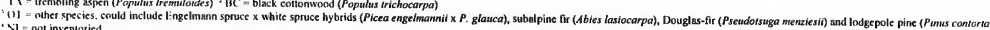



APPENDIX D (continued). TREMBLING ASPEN-BLACK COTTONWOOD TREE POPULATIONS BY SITE AND SPECIES DIAMETER CLASSES

DIAMETER CLASSES BY I AND 2 INCH INCREMENTS (CELL VALUES, NUMBER OF TREES PER ACRE)

\begin{tabular}{|c|c|c|c|c|c|c|c|c|c|c|c|c|c|c|c|c|c|c|c|c|c|c|c|c|c|c|c|}
\hline & & $1-2$ & 1 & & $2-4$ & 1 & $>$ & $4-6$ & 1 & & $>6-8$ & 1 & $>$ & $3-10$ & 1 & $>1$ & $10-12$ & 1 & $>1$ & $2-14$ & I & $>1$ & $14-16$ & 1 & -1 & 16 & \\
\hline $\begin{array}{l}411 \\
411 \\
10 \\
\end{array}$ & $\mathrm{IA}^{\prime}$ & $\mathrm{BC}^{\circ}$ & $\mathrm{OT}^{\prime}$ & TA & $\mathrm{BC}$ & OT & TA & $\mathrm{BC}$ & от & TA & BC & от & TA & BC & от & TA & $\mathrm{BC}$ & OT & TA & $B C$ & OT & TA & $\mathrm{BC}$ & Oा & $1 \mathrm{~A}$ & 13 & 01 \\
\hline $21^{\circ}$ & 150 & & & 390 & & & 30 & & & 40 & & & 90 & & & 110 & & & 10 & & & & & & & & \\
\hline 0280 & 10 & & & 20 & & & 0 & & & & & & & & & & & & & & & & & & & & \\
\hline $0=9 \mathrm{~L}$ & 10 & 20 & & 10 & & & 60 & & & 140 & & & 170 & & & 0 & & & & & & & & & & & \\
\hline $0=90$ & 40 & 0 & & 60 & & & 80 & & & 0 & & & 10 & & & 0 & & & & & & & & & & & \\
\hline $\mathrm{BrOH}$ & 50 & & & 210 & & & so & & & 10 & & & 10 & & & 20 & & & 10 & & & 0 & & & 0 & 10 & \\
\hline ก301 & 30 & & & 60 & & & 50 & & & 0 & & & 10 & & & 30 & & & 10 & & & 0 & & & 10 & & \\
\hline 0311 & IIII & & & 90 & & & 70 & & & 110 & & & 160 & & & 30 & & & 0 & & & & & & & & \\
\hline (1311) & 80 & & & 40 & & & 70 & & & 50 & & & 0 & & & & & & & & & & & & & & \\
\hline 0321 & 180 & 60 & & 210 & 40 & & 190 & 30 & & 260 & 10 & & 120 & & & & & & & & & & & & & & \\
\hline 0.20 & 50 & 10 & & 40 & 0 & & 20 & 0 & & 0 & $\theta$ & & & & & & . & & & & & & & & & & \\
\hline $0: 31$ & 10 & 20 & & 20 & 10 & 10 & 330 & 0 & & 190 & 0 & & 30 & 20 & & 0 & 10 & & & & & & & & & & \\
\hline $03: 0$ & 10 & 0 & & 60 & 0 & & 140 & 0 & & & & & & & & & & & & & & & & & & & \\
\hline $0 x+1$ & 110 & & & 120 & & & 370 & & & 130 & & & & & & & & & & & & & & & & & \\
\hline $03+0$ & 10 & & & 60 & & & 140 & & & 20 & & & & & & & & & & & & & & & & & \\
\hline 0351 & 190 & & & 430 & & & 70 & & & 90 & & & 70 & & & 0 & & & & & & & & & & & \\
\hline 0,300 & 120 & & & 70 & & & 50 & & & 40 & & & 20 & & & 30 & & & & & & & & & & & \\
\hline 0761. & 230 & 140 & & 210 & 70 & & 30 & 20 & & 10 & 40 & & 80 & 50 & & 10 & 40 & & 0 & 50 & & 0 & 40 & & & & \\
\hline$(0,3,0.1)$ & 0 & 0 & & 10 & 30 & & 30 & 20 & & 0 & 10 & & 0 & 30 & & 0 & 30 & & 0 & 10 & & & & & & & \\
\hline $037 \mathrm{~L}$ & 100 & 70 & 10 & 120 & 40 & & 30 & 20 & & 70 & 20 & & 60 & 0 & & 10 & 10 & & 0 & so & & 0 & 40 & & 0 & In & \\
\hline 0370 & 50 & 60 & & 10 & 0 & & 10 & 0 & & 0 & 0 & & & & & & & & & & & & & & & & \\
\hline
\end{tabular}

IA = trembling aspen (Populus tremuloides)

BC = hlack cotontwed (Foplius trichocarpa)

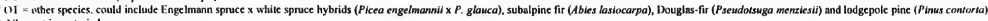

$\cdot \mathrm{N}=$ nol inventoried 

APPENDIX D (continued) TREMBLING ASPEN-BLACK COTTONWOOD TREE POPULATIONS BY SITE AND SPECIES DIAMETER CLASSES DIAMETER CLASSES BY 1 AND 2 INCH INCREMENTS (CELL VALUES, NUMBER OF TREES PER ACRE)

\begin{tabular}{|c|c|c|c|c|c|c|c|c|c|c|c|c|c|c|c|c|c|c|c|c|c|c|c|c|c|c|c|}
\hline & & $1-2$ & 1 & & $2-4$ & 1 & & $4-6$ & 1 & & $>6.8$ & 1 & $>$ & $8-10$ & 1 & & $10-12$ & 1 & $>1$ & $2-14$ & 1 & & $14-16$ & 1 & & 16 & \\
\hline $\begin{array}{l}411 \mathrm{E} \\
20 \\
\end{array}$ & $\mathbf{T A}^{\prime}$ & $\mathrm{BC}^{2}$ & от' & $\mathrm{TA}$ & $\mathrm{BC}$ & от & TA & $\mathrm{BC}$ & OT & TA & BC & OT & $\mathrm{TA}$ & BC & OT & TA & $B C$ & OT & TA & $\mathrm{BC}$ & OT & $\mathrm{TA}$ & $\mathrm{BC}$ & OT & $1 \mathrm{~A}$ & $B C$ & 191 \\
\hline $0 \div 81^{\circ}$ & 20 & & & 80 & & & 330 & & & 190 & & & 70 & & & 10 & & & 0 & & & & & & & & \\
\hline$(1: 81)$ & sil & & & 170 & & & 40 & & & 0 & & & & & & & & & & & & & & & & & \\
\hline $10 ; 91$ & $1+0$ & & & 210 & & & 120 & & & 80 & & & 60 & & & 20 & & & 10 & & & & & & & & \\
\hline 11390 & 60 & & & 40 & & & 0 & & & 0 & & & 10 & & & 0 & & & & & & & & & & & \\
\hline ROCL & 50 & 0 & 10 & 60 & & & 440 & & & 270 & & & 40 & & & 0 & & & & & & & & & & & \\
\hline OASOD & 10 & & & 110 & & & 120 & & & 10 & & & 0 & & & & & & & & & & & & & & \\
\hline "111. & 0 & & & 30 & & & 190 & 10 & & 260 & 40 & & 140 & 10 & & 30 & & & 0 & & & & & & & & \\
\hline 0410 & 20 & 0 & & 60 & 0 & & 10 & 0 & & 30 & 0 & & 0 & 0 & & 0 & 10 & & & & & & & & & & \\
\hline 0421 & 0 & & & 10 & & & 50 & & & 30 & & & 50 & 0 & 10 & 70 & & & 50 & 0 & 10 & 60 & & & 10 & & \\
\hline (0+21) & 30 & & & 20 & & & 0 & & & & & $\cdot$ & & & & & & & & & & & & & & & \\
\hline 10431 & 20 & & & 100 & & & 230 & & & 30 & 40 & & 0 & 10 & & 0 & & & 0 & & & 0 & 10 & & & & \\
\hline 0430 & 10 & 20 & & 140 & 10 & & 10 & 0 & & 0 & & & 0 & 20 & & & & & & & & & & & & & \\
\hline م+11 & 280 & 70 & & 510 & 100 & & 0 & 130 & & 0 & 30 & & 0 & 0 & & 0 & 40 & & 0 & 60 & & 0 & 10 & & 0 & 10 & \\
\hline (4)10 & 40 & 0 & & 0 & 60 & & 0 & 10 & & 0 & 0 & & 0 & 10 & & 0 & 0 & & 0 & 0 & & 0 & 10 & & & & \\
\hline ભำL. & $\mathrm{Nl}^{4}$ & & & & & & & & & & & & & & & & & & & & & & & & & & \\
\hline $145 \mathrm{D}$ & $\mathrm{NI}$ & & & & & & & & & & & & & & & & & & & & & & & & & & \\
\hline $0+61$. & 110 & $s_{0}$ & & 330 & 60 & & 90 & 40 & 10 & so & 0 & & 70 & 10 & & 60 & & & 10 & & & & & & & & \\
\hline (M)1 & 110 & 20 & & 70 & & & 40 & 0 & & 0 & & & 10 & & & & & & & & & & & & & & \\
\hline $14+7 \mathrm{~L}$. & 180 & 200 & & 60 & 40 & 10 & 20 & & & 40 & & & 40 & & & 10 & & & & & & & & & & & \\
\hline $\mathrm{A}^{\circ} \mathrm{D}$ & 0 & 20 & & 0 & 10 & & 0 & 10 & & 20 & 0 & & 0 & 10 & & & & & & & & & & & & & \\
\hline
\end{tabular}

TA = trembling aspen (Populus fremuloides)

BC = blach cottonwond (Populus trichocarpa)

OT = other species, could include Engelmann spruce $\mathrm{x}$ white spruce hybrids (Picea engelmannii x P. glauca), subalpine fir (Abies lasiocarpa), Douglas-fir (Pseudotsuga menziesii) and lodgepole pine (Ptrus contorla) $\cdot \mathrm{Nl}=$ not insentoried 
APPENDIX D (continued). TREMBLING ASPEN-BLACK COTTONWOOD TREE POPULATIONS BY SITE AND SPECIES DIAMETER CLASSES DIAMETER CLASSES BY 1 AND 2 INCH INCREMENTS (CELL VALUES, NUMBER OF TREES PER ACRE)

\begin{tabular}{|c|c|c|c|c|c|c|c|c|c|c|c|c|c|c|c|c|c|c|c|c|c|c|c|c|c|c|c|}
\hline & & $1-2$ & $I$ & & $2-4$ & I & & $4-6$ & I & & $>6-8$ & 1 & & $8-10$ & 1 & & $0-12$ & 1 & & $2-14$ & 1 & & $14-16$ & 1 & & 16 & \\
\hline $\begin{array}{l}\text { SIIE } \\
\vdots 11 \\
\end{array}$ & $I \mathbf{A}^{\prime}$ & $\mathrm{BC}^{\prime}$ & OT $^{\prime}$ & TA & $\mathrm{BC}$ & OT & TA & BC & Oт & $\mathrm{TA}$ & BC & от & TA & $\mathrm{BC}$ & OT & $\mathrm{TA}$ & BC & OT & TA & $\mathrm{BC}$ & OT & $\mathrm{TA}$ & $\mathrm{BC}$ & От & TA & $\mathrm{BC}$ & 011 \\
\hline $0+1 \times 1$ & 90 & 150 & & 40 & 150 & & 10 & 30 & & 30 & 20 & & 80 & 30 & & 10 & 30 & & & 20 & & 0 & 0 & & 0 & 211 & \\
\hline 0480 & 0 & 30 & & 0 & 60 & & 0 & 40 & & 30 & 10 & & 0 & 0 & & & & & & & & & & & & & \\
\hline 0491 & $\mathrm{NI}^{4}$ & & & & & & & & & & & & & & & & & & & & & & & & & & \\
\hline 0490 & NI & & & & & & & & & & & & & & & & & & & & & & & & & & \\
\hline $0 \leq 0 \mathrm{OL}$ & 30 & 120 & & 100 & 180 & 10 & 70 & 160 & 20 & 0 & 60 & 0 & 50 & 50 & & 20 & 30 & & 0 & 0 & & & & & & & \\
\hline $0 \leqslant 00$ & 20 & to & & 10 & 40 & & & & & 0 & 10 & & & & & 0 & 10 & & & & & & & & & & \\
\hline $0 \leqslant \mathrm{IL}$ & 70 & 70 & & 10 & 0 & & 0 & 10 & & 10 & 0 & & 100 & 0 & & 40 & 0 & & 0 & 0 & & & & & & & \\
\hline $0 \leq 10$ & 0 & 0 & & 0 & 20 & & 0 & 40 & & 20 & 0 & & so & 0 & & 40 & 0 & & 0 & 0 & & & & & & & \\
\hline 11521 & NI & & & & & & & & & & & & & & & & & & & & & & & & & & \\
\hline $0 \leqslant 20$ & $\mathrm{NI}$ & & & & & & & & & & & & & & & & & . & & & & & & & & & \\
\hline $0 \leq 31$ & $\mathrm{NI}$ & & & & & & & & & & & & & & & & & & & & & & & & & & \\
\hline$(1) ; 0 ; 1)$ & $\mathrm{NI}$ & & & & & & & & & & & & & & & & & & & & & & & & & & \\
\hline & & & & & & & & & & & & & & & & & & & & & & & & & & & \\
\hline & & & & & & & & & & & & & & & & & & & & & & & & & & & \\
\hline & & & & & & & & & & & & & & & & & & & & & & & & & & & \\
\hline & & & & & & & & & & & & & & & & & & & & & & & & & & & \\
\hline & & & & & & & & & & & & & & & & & & & & & & & & & & & \\
\hline & & & & & & & & & & & & & & & & & & & & & & & & & & & \\
\hline & & & & & & & & & & & & & & & & & & & & & & & & & & & \\
\hline & & & & & & & & & & & & & & & & & & & & & & & & & & & \\
\hline
\end{tabular}

1. Ine trees. 1). dead trees

IA = trembling aspen (Populus tremuloides)

lust trichocarpa)

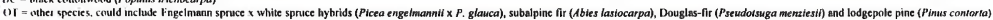

$\mathrm{Nl}=$ net insentoried 

APPENDIX E. TREMBLING ASPEN-BLACK COTTONWOOD BASAL AREA BY SITE, SPECIES, AND SAMPLING TECHNIQUE

BASAL AREA (FT'2/ACRE)

\begin{tabular}{|c|c|c|c|c|c|c|c|c|c|c|c|c|c|c|}
\hline \multirow{2}{*}{$\begin{array}{l}\text { SITE } \\
\text { NUMBER }\end{array}$} & \multicolumn{2}{|c|}{ POPTRE ${ }^{1}$} & \multicolumn{2}{|c|}{ POPTRI $^{2}$} & \multicolumn{2}{|c|}{ PICENG $^{3}$} & \multicolumn{2}{|c|}{ ABILAS $^{4}$} & \multicolumn{2}{|c|}{$\mathrm{PINCON}^{5}$} & \multicolumn{2}{|c|}{ TOTAL } & \multicolumn{2}{|c|}{ TOTAL } \\
\hline & LIVE & DEAD & LIVE. & DEAD & LIVE & DEAD & LIVE & DEAD & LIVE & DEAD & LIVE & DEAD & LIVE & DEAD \\
\hline 017 & 86.7 & 6.5 & & & & & & & & & 86.7 & 6.5 & 57 & $\mathrm{NI}$ \\
\hline 018 & 66.5 & 4.1 & & & & & & & & & 66.5 & 4.1 & 72 & 25 \\
\hline 019 & 43.0 & 4.1 & 88.6 & 7.3 & & & & & & & 131.6 & 11.4 & 124 & NI \\
\hline 020 & 171.5 & 9.9 & & & & & & & & & 171.5 & 9.9 & 156 & $\mathrm{~N} 1$ \\
\hline 021 & 135.8 & 9.8 & 22.4 & 43.9 & & & & & & & 158.2 & 53.7 & 125 & NI \\
\hline 022 & N1 & & & & & & & & & & & & 120 & NI \\
\hline 023 & 115.8 & 0 & 96.6 & 0.1 & & & & & & & 212.4 & 0.1 & 160 & NI \\
\hline 024 & 51.0 & 47.2 & & & & & & & & & 51.0 & 47.2 & 65 & 12 \\
\hline 025 & 64.7 & 6.1 & 33.5 & 5.3 & & & & & & & 98.2 & 11.4 & 85 & 20 \\
\hline 026 & 44.4 & 0 & 114.9 & 6.9 & & & & & & & 159.3 & 6.9 & 90 & N1 \\
\hline 027 & 88.3 & 10.6 & 57.1 & 9.6 & & & & & & & 145.4 & 20.2 & 120 & NI \\
\hline 028 & 142.9 & 1.4 & & & & & & & & & 142.9 & 1.4 & 80 & NI \\
\hline 029 & 120.6 & 19.1 & 0.2 & 0 & & & & & & & 120.8 & 19.1 & 60 & 12 \\
\hline 030 & 45.4 & 43.3 & 1.4 & 0 & & & & & & & 46.8 & 43.3 & 50 & 25 \\
\hline 031 & 133.3 & 25.5 & & & 31.0 & 0 & & & & & 164.3 & 25.5 & 88 & 04 \\
\hline 032 & 160.0 & 5.1 & 8.8 & 0.1 & & & & & & & 168.8 & 5.2 & 122 & 04 \\
\hline 033 & 108.6 & 20.6 & 16.3 & 0 & 0.7 & 0 & & & & & 125.6 & 20.6 & 72 & 08 \\
\hline 034 & 85.2 & 27.2 & & & & & & & & & 85.2 & 27.2 & 50 & 10 \\
\hline 035 & 81.0 & 47.9 & & & & & & & & & 81.0 & 47.9 & 65 & 20 \\
\hline 036 & 75.5 & 4.7 & 157.9 & 46.3 & & & & & & & 233.4 & 51.0 & 140 & 32 \\
\hline
\end{tabular}

${ }^{1} \mathrm{POPTRE}=$ Populus tremuloides $;{ }^{2} \mathrm{POPTRI}=$ Populus trichocarp $; ;{ }^{3} \mathrm{PICENG}=$ Picea engelmannii; ${ }^{4} \mathrm{ABILAS}=$ Abies lasiocarpa $;{ }^{5} \mathrm{PINCON}=$ Pinus contorta 

APPENDIX E (cont.). TREMBLING ASPEN-BLACK COTTONWOOD BASAL AREA BY SITE, SPECIES, AND SAMPLING TECHNIQUE

BASAL AREA (FT²/ACRE)

\begin{tabular}{|c|c|c|c|c|c|c|c|c|c|c|c|c|c|c|}
\hline \multirow{2}{*}{$\begin{array}{l}\text { SITE } \\
\text { NUMBER }\end{array}$} & \multicolumn{2}{|c|}{ POPTRE $^{1}$} & \multicolumn{2}{|c|}{ POPTRI $^{2}$} & \multicolumn{2}{|c|}{$\mathrm{PICENG}^{3}$} & \multicolumn{2}{|c|}{ ABILAS $^{4}$} & \multicolumn{2}{|c|}{$\mathrm{PINCON}^{5}$} & \multicolumn{2}{|c|}{ TOTAL } & \multicolumn{2}{|c|}{ TOTAL } \\
\hline & LIVE & DEAD & LIVE & DEAD & LIVE & DEAD & LIVE & DEAD & LIVE & DEAD & LIVE & DEAD & LIVE & DEAD \\
\hline 037 & 61.7 & 2.0 & 166.1 & 0.7 & & & 0.1 & 0 & & & 227.9 & 2.7 & 144 & 20 \\
\hline 038 & 133.5 & 14.6 & & & & & & & 0.1 & 0 & 133.6 & 14.6 & 85 & 7.5 \\
\hline 039 & 101.6 & 6.3 & & & & & & & & & 101.6 & 6.3 & 72 & 0 \\
\hline 040 & 155.9 & 23.5 & & & 0.1 & 0 & & & & & 160.0 & 23.5 & 96 & 0 \\
\hline 041 & 177.5 & 11.2 & 17.7 & 6.0 & & & & & & & 195.2 & 17.2 & 108 & 12 \\
\hline 042 & 206.8 & 0.5 & & & 4.9 & 0 & & & · $\quad 9.9$ & 0 & 221.6 & 0.5 & 104 & 02 \\
\hline 043 & 44.6 & 6.2 & 26.1 & 8.4 & & & & & & & 70.7 & 14.6 & 87 & 06 \\
\hline 044 & 15.6 & 0.5 & 136.8 & 22.1 & & & & & & & 152.4 & 22.6 & 72 & 08 \\
\hline 045 & $\mathrm{~N} 1$ & NI & & & & & & & & & & . & NI & NI \\
\hline 046 & 116.3 & 13.9 & 3.3 & 0.2 & & & & & & & 121.3 & 14.1 & 80 & 04 \\
\hline 047 & 42.6 & 5.3 & 121.7 & 5.8 & 0.3 & 0 & & & & & 164.6 & 11.1 & 102 & 0 \\
\hline 048 & 49.0 & 7.7 & 123.2 & 9.8 & & & & & & & 172.2 & 17.5 & 100 & 10 \\
\hline 049 & N1 & & & & & & & & & & & & 55 & 65 \\
\hline 050 & 50.2 & 0.5 & 96.4 & 12.5 & 2.5 & 0 & & & & & 149.1 & 13.0 & 88 & 16 \\
\hline 051 & 77.8 & 51.8 & 2.5 & 6.2 & & & & & & & 80.3 & 58.0 & 48 & 08 \\
\hline 052 & $\mathrm{Nl}$ & & & & & & & & & & & & 70 & 40 \\
\hline 053 & Nl & & & & & & & & & & & & $\mathrm{N} 1$ & $\mathrm{Nl}$ \\
\hline $\begin{array}{l}\text { MEAN } \\
\text { BASAL } \\
\text { AREA }\end{array}$ & 90.4 & 13.7 & 40.4 & 4.5 & 1.2 & 0 & $<0.01$ & 0 & 0.3 & 0 & 132.3 & 19.6 & 92 & 14 \\
\hline
\end{tabular}

POPTRE $=$ Populus tremuloides,${ }^{2}$ POPTRI $=$ Populus trichocarpa,${ }^{3}$ PICENG $=$ Picea engelmannii; ${ }^{4}$ ABILAS $=$ Abies lasiocarpa $;{ }^{5} \mathrm{PINCON}=$ Pinus contorta 
Appendix F. Vascular plant species occurring in aspen and black cottonwood stands; arranged by decreasing lifeform size and alphabetically within lifeform and including U.S. Fish and Wildlife Service wetland indicator status by administrative region.

\begin{tabular}{llll}
\hline LIFEFORM & SCIENTIFIC NAME & COMMON NAME & REGION 4 \\
\hline 1: Trees & REGION 9 & FACU 1 \\
\cline { 2 - 4 } & Abies lasiocarpa & Fic, Subalpine & FAC \\
\cline { 2 - 4 } & Picea glauca (x engelmannii) & Spruce, Engelmann & FAC \\
\cline { 2 - 4 } & Pinus contorta & Spruce, White x Engelmann & FAC- \\
\cline { 2 - 4 } & Pinus flexilis & Pine, Lodgepole & FACU \\
\cline { 2 - 4 } & Populus balsamifera (ssp. trichocarpa) & Pine, Limber & FACW \\
\cline { 2 - 4 } & Populus tremuloides & Aspen, Trembling & FAC+ \\
\cline { 2 - 4 } & Pseudotsuga menziesii & Douglas-fir & FACW \\
\hline
\end{tabular}

2: Shrubs

\begin{tabular}{|c|c|c|c|}
\hline Amelanchier alnifolia & Serviceberry, Westem & FACU & FACU \\
\hline Betula occidentalis & Birch, Water & FACW & FACW \\
\hline Cornus stolonifera & Dogwood, Red-osier & FACW & FACW \\
\hline Crataegus douglasii & Hawthorn, Black & FAC & NO \\
\hline Frangula (Rhamnus) purshiana & Buckthom, Cascara & $\underline{-}$ & 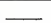 \\
\hline Juniperus communis & Juniper, Common & 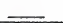 & \\
\hline Lonicera involucrata & Honeysuckle, Twin-berry & FAC & NO \\
\hline Lonicera utahensis & Honeysuckle, Utah & FACU+ & No \\
\hline Mahonia (Berberis) repens & Oregon-grape, Creeping & $\underline{-}$ & $\ldots$ \\
\hline Potentilla floribunda (fruticosa) & Cinquefoil, Shrubby & FAC- & FACW \\
\hline Prunus virginiana & Chokecherry, Common & FACU & FACU- \\
\hline Rhamnus alnifolia & Buckthorn, Alder & FACU & NI \\
\hline Ribes americanum & Currant, Black & FAC & FACW \\
\hline Ribes lacustre & Currant, Swamp & FAC+ & FACW \\
\hline Ribes oxyacanthoides (setosum) & Gooseberry, Missouri & $\underline{-}$ & NI \\
\hline Rosa acicularis & Rose, Prickly & FACU & FACU \\
\hline Rosa woodsii & Rose, Wood's & FACU & FACU \\
\hline Rubus idaeus & Raspberry, Red & FACU & FACU \\
\hline Rubus parviflorus & Thimbleberry & FACU+ & FACU \\
\hline Salix bebbiana & Willow, Bebb & FACW & FACW \\
\hline Salix boothii & Willow, Booth & FACW & 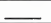 \\
\hline Salix geyeriana & Willow, Geyer & FACW+ & OBL \\
\hline Salix tutea & Willow, Watson & FACW+ & OBL \\
\hline Salix scouleriana & Willow, Scouler & FAC & FACU \\
\hline Salix tweedyi & Willow, Tweedy's & FACW+ & - \\
\hline Shepherdia canadensis & Buffaloberry, Canada & 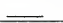 & $\underline{ }$ \\
\hline Sorbus scopulina & Mountain-ash, Cascade & NI & NI \\
\hline Spiraea betulifolia & Spiraea, Shiny-leaf & $\underline{-}$ & - \\
\hline Symphoricarpos albus & Snowberry, Common & FACU & FACU \\
\hline
\end{tabular}

3: Graminoids

Agrostis scabra

Alopecurus borealis (alpinus)

Alopecurus pratensis

Bromus ciliatus

Bromus inermis (ssp. pumpellianus
Tickle-grass

Foxtail, Alpine

Foxtail, Meadow

Brome, Fringed

Brome, Pumpelly
FAC

FACW

FACW

FAC+

(1)
FAC

NO

FACW

FAC 


\begin{tabular}{|c|c|c|c|c|}
\hline LIFEFORM & SCIENTIFIC NAME & COMMON NAME & REGION 4 & REGION 9 \\
\hline & Calamagrostis canadensis & Reedgrass, Bluejoint & FACW+ & FACW+ \\
\hline & Calamagrostis rubescens & Pinegrass & - & 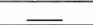 \\
\hline & Calamagrostis stricta & Reedgrass, Narrow-spiked & FACW & OBL \\
\hline & Carex brevior & Sedge, Short-beaked & $\mathrm{OBL}$ & FACU \\
\hline & Carex geyeri & Sedge, Elk & $\underline{-}$ & $\bar{c}$ \\
\hline & Carex hoodii & Sedge, Hood's & $\mathrm{NI}$ & NI \\
\hline & Carex microptera & Sedge, Small-wing & FAC & FAC \\
\hline & Carex raynoldsii & Sedge, Raynolds' & FACU & NO \\
\hline & Carex rostrata & Sedge, Beaked & $\mathrm{OBL}$ & $\mathrm{OBL}$ \\
\hline & Cinna latifolia & Woodreed, Drooping & FACW & $\mathrm{OBL}$ \\
\hline & Dactylis glomerata & Orchard-grass & FACU & FACU \\
\hline & Deschampsia cespitosa & Hairgrass, Tufted & FACW & FACW \\
\hline & Elymus glaucus & Wildrye, Blue & FACU & FACU \\
\hline & Elytrigia (Agropyron) repens & Quackgrass & FACU & FAC \\
\hline & Festuca subulata & Fescue, Bearded & FAC & UPL \\
\hline & Juncus balticus & Rush, Baltic & OBL & OBL \\
\hline & Melica subulata & Oniongrass, Alaska & FAC & 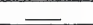 \\
\hline & Phleum pratense & Timothy, Common & FACU & FACU \\
\hline & Poa interior & Bluegrass, Inland & FAC & FAC \\
\hline & Poa palustris & Bluegrass, Fowl & FACW & FACUW \\
\hline & Poa pratensis & Bluegrass, Kentucky & FACU & FACU+ \\
\hline & Schizachne purpurascens & False Melic & UPL & FACU \\
\hline & Stipa occidentalis & Needlegrass, Western & - & $\overline{-}$ \\
\hline \multicolumn{5}{|l|}{ 4: Forbs } \\
\hline & Achillea millefolium & Yarrow, Common & FACU & FACU \\
\hline & Actaea rubra & Baneberry & 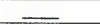 & 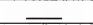 \\
\hline & Allium cemuum & Onion, Nodding & 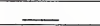 & $\underline{L}$ \\
\hline & Allium schoenoprasum & Chives & FACW+ & NO \\
\hline & Angelica arguta & Angelica, Sharptooth & FACW & 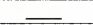 \\
\hline & Arabis glabra & Towermustard & $\ldots$ & - \\
\hline & Arabis hirsuta & Rockcress, Hairy & FACU & - \\
\hline & Arnica chamissonis & Arnica, Meadow & FACW & 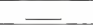 \\
\hline & Aster conspicuus & Aster, Showy & $\bar{C}$ & - \\
\hline & Aster engelmannii & Aster, Engelmann's & $\bar{L}$ & - \\
\hline & Aster foliaceus & Aster, Leafy & FACW- & NO \\
\hline & Aster laevis & Aster, Smooth & - & $=$ \\
\hline & Camassia quamash & Camas, Common & FACW & $=$ \\
\hline & Campanula rotundifolia & Harebell & FACU & FAC \\
\hline & Castilleja lutescens & Stiff Yellowish Indian Paintbrush & FAC & NO \\
\hline & Castilleja miniata & Greater Red Indian Paintbrush & FAC & FAC \\
\hline & Castilleja rhexiifolia & Rhexia-leaf Indian Paintbrush & FAC & No \\
\hline & Cirsium arvense & Thistle, Canada & FACU+ & FACU \\
\hline & Cirsium hookerianum & Hooker Thistle & $\underline{-}$ & 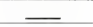 \\
\hline & Cirsium scariosum & Thistle, Elk & $\underline{-}$ & $\underline{-}$ \\
\hline & Cirsium vulgare & Thistle. Bull & FACU & UPL \\
\hline & Descurainia pinnata & Tansymustard, Pinnate & - & $\underline{-}$ \\
\hline & Disporum hookeri & Fairy-bell, Hooker & $\ldots$ & $\ldots$ \\
\hline & Disporum trachycarpum & Fairy-bell, Wartberry & $\mathrm{NI}$ & NI \\
\hline & Epilobium angustifolium & Fireweed & FACU+ & FAC \\
\hline
\end{tabular}




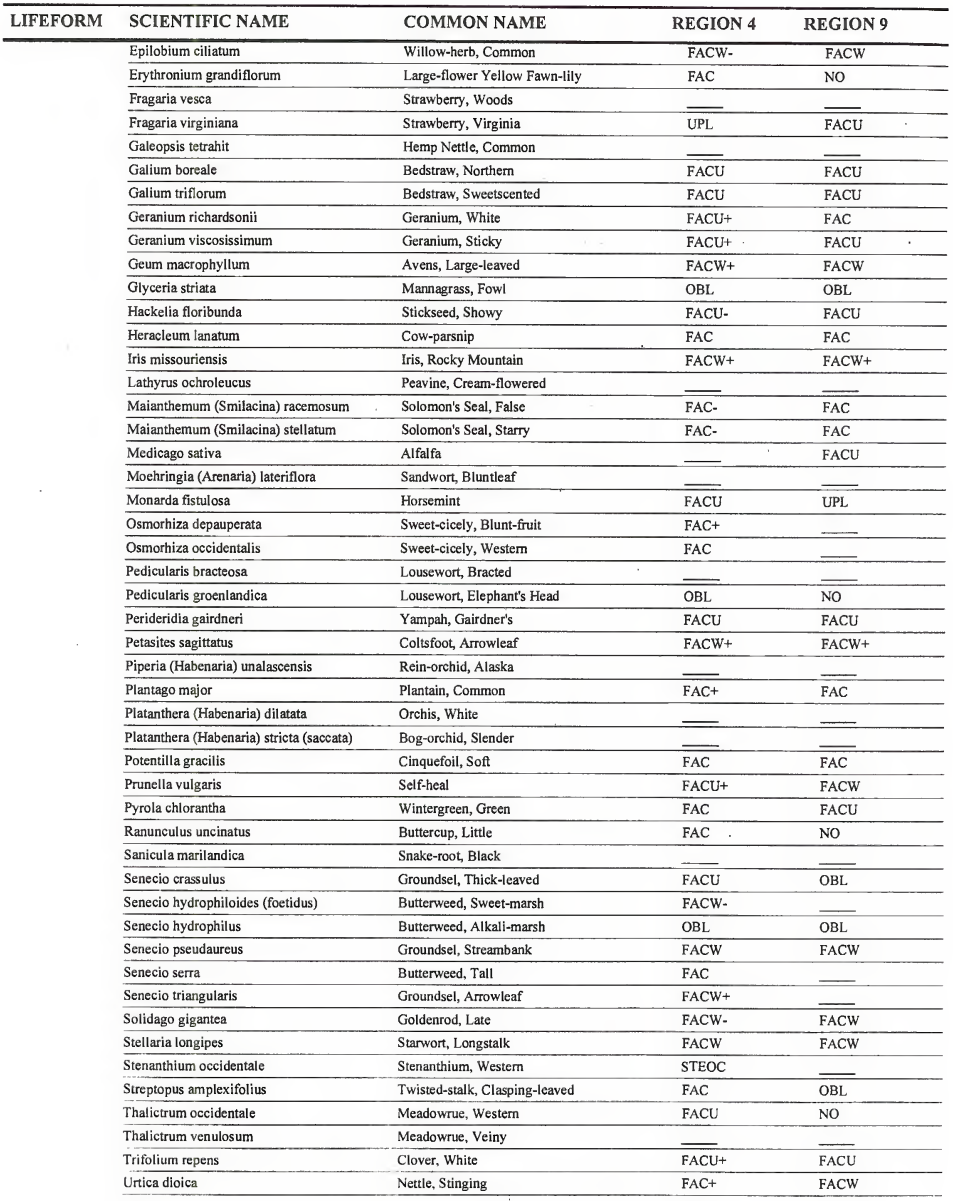





\begin{tabular}{|c|c|c|c|c|}
\hline LIFEFORM & SCIENTIFIC NAME & COMMON NAME & REGION 4 & REGION 9 \\
\hline & Valeriana sitchensis & Valerian, Sitka & FAC & $=$ \\
\hline & Veratrum viride & False Hellebore, Green & OBL & \\
\hline & Vicia americana & Vetch, American & 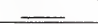 & $\longrightarrow$ \\
\hline & Viola canadensis & Viola, Canada & FAC & - \\
\hline & Zigadenus elegans & Death-camas, Glaucous & FAC+ & 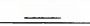 \\
\hline \multicolumn{5}{|c|}{ 5: Ferns \& Fern allies } \\
\hline & Botrychium virginianum & Grape-fern, Virginia & FACU & FACU \\
\hline
\end{tabular}

1 Wetland indicator status designations: OBL (obligate wetland species, those that almost always occur, i.e. with problability $>99 \%$, in wetlands under natural conditions), FACW (facultative wetland species those that usually occur in wetlands, i.e. with estimated probability of $67-99 \%$, but is occasionally found in non-wetlands, FAC (facultative species, those equally likely to occur in wetlands, i.e. estimated probability $34-66 \%$, or uplands), FACU (facultative upland species, those that usually occur in non-wetlands, i.e. with an estimated probability of $67-99 \%$ ) and $U$ (upland species, those found almost always in uplands, i.e. with a probability of $>99 \%$ ). Wetland categories and their values for species are from Reed (1988a and 1988b); for some species no information was available (blank entries in matrix cells). 

Appendix G. Application of comprehensive onsite determination method ${ }^{*}$ to selected trembling aspen-black cottonwood stands.

Plot Number: Sc017

Dominant Wetland Strat.

Plant Indicator

Species Status

POPTRE FAC+ T

CORSTO FACW S

THAOCC FACU $\mathrm{H}$

GERRIC FAC $\mathrm{H}$

OSMDEP FAC+ $\mathrm{H}$

- - - - - -

$-----ー \square-$
$------\square$

-ーーーーー -

- - - - - -

- - - - - -

- - - - -

- - - - -

$------\square$

Percent of Dominant Spp. That Are:

$$
\text { OBL: } 0
$$

FACW: 20

\section{FAC+/FAC: 40}

Total \% Wetlnd. Spp. 60 Hydroph. Veg. Y: $x$ N: Hydric Soil: $\quad \mathrm{Y}: \mathrm{x} \mathrm{N}$ :Wtind. Hydro. $\mathrm{Y}$ : $\times \mathrm{N}$ :

Jurisdic. WtInd. $\mathrm{Y}: \times \mathrm{N}$ :_
Plot Number: SC018

Dominant Wetland Strat.

Plant

Indicator

Species Status

POPTRE FAC+ T

SYMALB FACU S

PRUVIR FACU S

VIOCAN FAC H

OSMOCC FAC H

HERLAN FAC H

ELYGLA FACU H

GUEMAC FACW+ $\mathrm{H}$

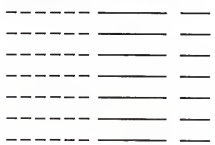

Percent of Dominant Spp.

That Are:

OBL: 0

FACW: 12

\section{FAC+/FAC: 50}

Total \% Wetlnd. Spp. 62

Hydroph. Veg. $\mathrm{Y}: \mathrm{X} \mathrm{N}$ :

Hydric Soil: Y: ? N:-

Wtind. Hydro. Y: $\times$ N:-

Jurisdic. Wtind. $\mathrm{Y}: \times \mathrm{N}$ :-
Plot Number: SC019

Dominant Wetland Strat.

Plant Indicator

Species Status

$\begin{array}{lll}\text { POPTRE } & \text { FAC+ } & \text { T } \\ \text { POPTRI } & \text { FACW } & \text { T } \\ \text { LONINV } & \text { FAC } & \text { S } \\ \text { SYMALB } & \text { FACU } & \text { S } \\ \text { OSMOCC } & \text { FAC } & \text { H } \\ \text { HERLAN } & \text { FAC } & \text { H } \\ \text { ELYGLA } & \text { FACU } & \text { H }\end{array}$

$------\square$

------ $\square-$

------ $-\square-$

- - - - -

------

$------$

Percent of Dominant Spp.

That Are:

OBL: 0
FACW: 14

FAC+/FAC: 57

Total \% Wetlnd. Spp. 71

Hydroph. Veg. Y: $x$ N:

Hydric Soil: $\quad$ Y: $\times$ N:-

Wtind. Hydro. $\mathrm{Y}: \times \mathrm{N}$ :

Jurisdic. Wtind. $\mathrm{Y}: \times \mathrm{N}$ :
Plot Number: SC020

Dominant Wetland Strat.

Plant

Indicator

Species Status

$\begin{array}{lll}\text { POPTRE } & \text { FAC+ } & \text { T } \\ \text { SYMALB } & \text { FACU } & \text { S } \\ \text { OSMOCC } & \text { FAC } & H \\ \text { SENPSE } & \text { FACW } & H \\ \text { VIOCAN } & \text { FAC } & H \\ \text { ELYGLA } & \text { FACU } & H \\ \text { ERYGRA } & \text { FAC } & H\end{array}$

ERYGRA FAC $\mathrm{H}$

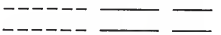

- - - $\longrightarrow$

- - - - -

- - - $\square--\square$

- - - - - -

Percent of Dominant Spp .

That Are:

$$
\text { OBL: } 0
$$

FACW: 14

FAC+/FAC: 57

Total \% Wetlnd. Spp. 71 Hydroph. Veg. Y: x N:

Hydric Soil: $\quad Y:-N: \bar{x}$ Wtind. Hydro. $\mathrm{Y}: \overline{\mathrm{T}} \mathrm{N}$ :

Jurisdic. Wtind. $\mathrm{Y}: \ldots \mathrm{N}: \mathrm{x}$
Plot Number: SCO21

Dominant Wetland Strat.

Plant Indicator

Species Status

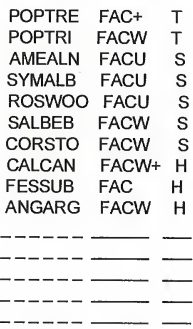

Percent of Dominant Spp. That Are:

$$
\begin{aligned}
& \text { OBL: } 0 \\
& \text { FACW: } 50
\end{aligned}
$$

FAC+/FAC: 20

Total \% Wetlnd. Spp. 70 Hydroph. Veg. $Y: x N$ : Hydric Soil: $\quad \mathrm{Y}: \times \mathrm{N}$ : Wtind. Hydro. Y: $\times \mathrm{N}:$

Jurisdic. Wtind. $\mathrm{Y}: \times \mathrm{N}$ :-

*Federal Manual for Identifying and Delineating Jurisdictional Wetlands (1987) 

Appendix G (Continued). Application of comprehensive onsite determination method* to selected trembling aspen-black cottonwood stands.

Plot Number: SC022

Dominant Wetland Strat.

Plan Indicator

Species Status

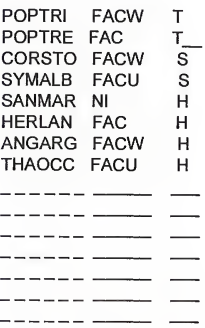

Percent of Dominant Spp. That Are:

OBL: 0

FACW: 43

\section{FAC+/FAC: 29}

Total \% Wetlnd. Spp. 72

Hydroph. Veg. Y: $x \mathrm{~N}$ :

Hydric Soil: $\quad Y: \times \mathrm{N}:$

Wtind. Hydro. $Y: \times \mathrm{N}$ :

Jurisdic. Wtind. $\mathrm{Y}: \mathrm{x} \mathrm{N}:$
Plot Number: SC023

Dominant Wetland Strat.

Plant Indicator

Species Status

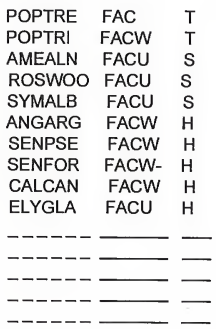

Percent of Dominant Spp.

That Are:

$$
\text { OBL: } 0
$$

FACW: 50

FAC+/FAC: 20

Total \% Wetlnd. Spp. 70

Hydroph. Veg. Y: $x$ N:

Hydric Soil: $\quad Y: X N:$

Wind. Hydro. $Y: x N$ :

Jurisdic. Wtind. $\mathrm{Y}: \mathrm{x} \mathrm{N}$ :
Plot Number: SC024

Dominant Wetland Strat.

Plant

Indicator

Species Status

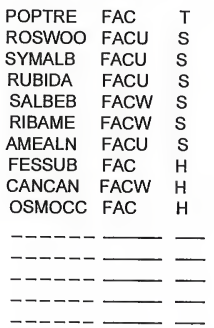

Percent of Dominant Spp. That Are:

$$
\begin{gathered}
\text { OBL: } 0 \\
\text { FACW: } 36
\end{gathered}
$$

FAC+/FAC: 27

Total \% Wetlnd. Spp. 63

Hydroph. Veg. Y: $x$ N:

Hydric Soil: $\quad Y: \times N$ :

Wtind. Hydro. Y: ? N:?

Jurisdic. WtInd. Y: ? N:
Plot Number: $\mathrm{SC} 025$

Dominant Wetland Strat.

Plant

Species

Indicator

POPTRI FACW T

POPTRE FAC T

SYMALB FACU S

RIBAME FACW S

ELYGLA FACU H

HERLAN FAC H

VIOCAN FAC $\mathrm{H}$

- - - - - -

-ー-ー-ー $\square$

-ーーーーー -

- - - - -

--ー-ーー —

Percent of Dominant Spp .

That Are:

$$
\begin{gathered}
\text { OBL: } 0 \\
\text { FACW: } 29
\end{gathered}
$$

FAC+/FAC: 43

Total \% Wetind. Spp. 72 Hydroph. Veg. Y: $x$ N: Hydric Soil: $\quad Y: \times N:$ Wtind. Hydro. Y: $\times$ N:-

Jurisdic. WtInd. $\mathrm{Y}: \mathrm{X} \mathrm{N}$ :
Plot Number: SC026

Dominant Wetland Strat.

Plant Indicator

Species Status

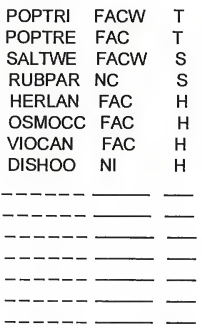

Percent of Dominant Spp. That Are:

$$
\begin{gathered}
\text { OBL: } 0 \\
\text { FACW: } 25
\end{gathered}
$$

FAC+/FAC: 50

Total \% Wetlnd. Spp. 75 Hydroph. Veg. Y: $x$ N: Hydric Soil: $Y: ? N$ : Wtind. Hydro. $\mathrm{Y}: \ldots \mathrm{N}: \overline{\mathrm{X}}$

Jurisdic. Wtind. $\mathrm{Y}: \ldots \mathrm{N}: \mathrm{X}$

* Federal Manual for Identifying and Delineating Jurisdictional Wetlands (1987) 

Appendix G (Continued). Application of comprehensive onsite determination method ${ }^{*}$ to selected trembling aspen-black cottonwood stands.

Plot Number: SC027

Dominant Wetland Strat.

Plant Indicator

Species Status

$\begin{array}{lll}\text { POPTRI } & \text { FACW } & \text { T } \\ \text { POPTRE } & \text { FAC } & \text { T } \\ \text { SYMALB } & \text { FACU } & \text { S } \\ \text { SALLUT } & \text { FACW } & \text { S } \\ \text { ELYGLA } & \text { FACU } & \text { H } \\ \text { HERLAN } & \text { FAC } & \text { H } \\ \text { VERVIR } & \text { FACW } & \text { H } \\ \text { DISHOO } & \text { NI } & \text { H }\end{array}$

$-----\longrightarrow$

$----\longrightarrow$

-ー-ーーー $\square$

- - - - - -

$-----\square-\square$

- - - - - -

Percent of Dominant Spp. That Are:

OBL: 10

FACW: 20

FAC+/FAC: 40

Total \% Wetlnd. Spp. 70 Hydroph. Veg. $\mathrm{Y}: \times \mathrm{N}$ : Hydric Soil: $\quad \mathrm{Y}: \times \mathrm{N}$ :Wtind. Hydro. $\mathrm{Y}: \times \mathrm{N}$ :

Jurisdic. Wtind. $\mathrm{Y}: \mathrm{x} \mathrm{N}$ :
Plot Number: SC028

Dominant Wetland Strat.

Plant Indicator

Species Status

POPTRE FAC T

SYMALB FACU $S$

OSMOCC FAC H

FRAVIR UPL H

------ $-\square$

------ $\square-$

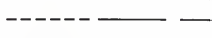

$------\square$

----- -

-ーーーーー

--ー-ー- $\square$

------ - -

------

Percent of Dominant Spp.

That Are:

$$
\text { OBL: } 0
$$

FACW: 0

FAC+/FAC: 50

Total \% Wetlnd. Spp. 50 Hydroph. Veg. Y: $x \mathrm{~N}: \mathrm{X}$ Hydric Soil: $\quad Y:-N: x$ Wtind. Hydro. $\mathrm{Y}:-\mathrm{N}: \mathrm{x}$

Jurisdic. Wtind. $\mathrm{Y}: \mathrm{N}: \mathrm{X}$
Plot Number: SC029

Dominant Wetland Strat.

Plant Indicator

Species Status

POPTRE FAC T

SYMALB FACU S

ELYGLA FACU H

HERLAN FAC H

OSMOCC FAC H

VIOCAN FAC H

THAOCC FACU H

$------\square-$

---- $\square-$

$-----\square$

----- -

----- -

$------\square$

- - - - -

Percent of Dominant Spp.

That Are:

OBL: 0

FACW: 0

FAC+/FAC: 57

Total \% Wetlnd. Spp. 57 Hydroph. Veg. Y: $x \mathrm{~N}$ :

Hydric Soil: $\quad \mathrm{Y}: \mathrm{N}: \overline{\mathrm{x}}$

Wtind. Hydro. $\mathrm{Y}:-\mathrm{N}: \mathrm{X}$

Jurisdic. Wtind. $\mathrm{Y}: \ldots \mathrm{N}: \mathrm{x}$
Plot Number: $\mathrm{SC030}$

$\begin{array}{ll}\text { Dominant } & \text { Wetland Strat. } \\ \text { Plant Indicator }\end{array}$

Species Status

POPTRE FAC T

POPTRI FACW T

SYMALB FACU S

AMEALN FACU S

SPIBET NI S

ELYGLA FACU $\mathrm{H}$

FESSUB FAC H

HERLAN FAC H

THAOCC FACU $\mathrm{H}$

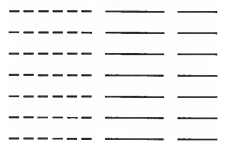

Percent of Dominant Spp . That Are: OBL: 0

FACW: 11

FAC+/FAC: 33

Total \% Wetlnd. Spp. 44 Hydroph. Veg. Y:_ N: $\mathrm{x}$ Hydric Soil: $\quad Y:-N: x$ Wtind. Hydro. $\mathrm{Y}: \mathrm{N}: \mathrm{x}$ Jurisdic. Wtind. $\mathrm{Y}: \ldots \mathrm{N}: \mathrm{x}$
Plot Number: $\mathrm{Sc} 031$

\section{Dominant Wetland Strat \\ Plant Indicator \\ Species Status

$\begin{array}{lll}\text { POPTRE } & \text { FAC } & \mathrm{T} \\ \text { PICENG } & \text { FAC } & \mathrm{T} \\ \text { ROSWOO } & \text { FACU } & \mathrm{S} \\ \text { SYMALB } & \text { FACU } & \mathrm{S} \\ \text { SENPSE } & \text { FACW } & \mathrm{H} \\ \text { GERRIC } & \text { FACU } & \mathrm{H} \\ \text { ANGARG } & \text { FACW } & \mathrm{H}\end{array}$

$------\square$
$------\square$
$------\square$
$------\square$
$------\square$
$------\square$
$------\square$
$------\square$
$------\square$

Percent of Dominant Spp. That Are:

OBL: 0

FACW: 28

FAC+/FAC: 28

Total \% Wetind. Spp. 57 Hydroph. Veg. Y: $x \mathrm{~N}$ :Hydric Soil: $\quad \mathrm{Y}: \times \mathrm{N}:$ Wtind. Hydro. Y: x N:-

Jurisdic. Wtind. $\mathrm{Y}: \mathrm{x} \mathrm{N}$ :

* Federal Manual for Identifying and Delineating Jurisdictional Wetlands (1987) 

Appendix G (Continued). Application of comprehensive onsite determination method to selected trembling aspen-black cottonwood stands.

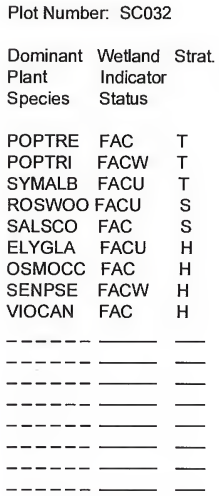

Percent of Dominant Spp. That Are:

OBL: 0

FACW: 20

\section{FAC+/FAC: 50}

Total \% Wetind. Spp. 70 Hydroph. Veg. $Y: x$ N: Hydric Soil: $\quad Y:-N: \bar{x}$ Wtind. Hydro. $\mathrm{Y}:-\mathrm{N}: \mathrm{X}$

Jurisdic. Wtind. $\mathrm{Y}: \mathrm{N}_{\mathrm{N}} \mathrm{X}$
Plot Number: SC033

Dominant Wetland Strat.

Plant Indicator

Species Status

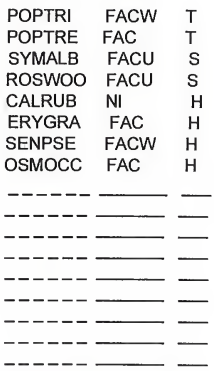

Percent of Dominant Spp. That Are:

$$
\text { OBL: } 0
$$

FACW: 25

FAC+/FAC: 37

Total \% Wetlnd. Spp. 62 Hydroph. Veg. $Y: x \quad N$ :

Hydric Soil: $\quad Y:-N: \bar{x}$ Wtind. Hydro. $Y:-N: X$

Jurisdic. Wtind. $\mathrm{Y}: \mathrm{N}_{\mathrm{N}} \mathrm{x}$
Plot Number: $\mathrm{Sc034}$

Dominant Wetland Strat.

Plant

Species Status

$\begin{array}{lll}\text { POPTRE } & \text { FAC } & \text { T } \\ \text { SALSCO } & \text { FAC } & \text { S } \\ \text { SYMALB } & \text { FACU } & \text { S } \\ \text { SANMAR } & \text { NI } & \text { H } \\ \text { PHLPRA } & \text { FACU } & \text { H } \\ \text { ELYGLA } & \text { FACU } & \text { H } \\ \text { POAPRA } & \text { FACU } & \text { H } \\ \text { ANGARG } & \text { FACW } & \text { H }\end{array}$

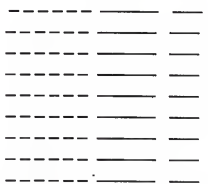

Percent of Dominant Spp. That Are:

OBL: 0
FACW: 12

FAC+/FAC: 25

Total \% Wetlnd. Spp. 37 Hydroph. Veg. Y: $-\mathrm{N}: \mathrm{x}$ Hydric Soil: $\quad Y:-N: X$ Wtind. Hydro. $Y:-N: X$

Jurisdic. Wtind. $Y: \ldots N: x$
Plot Number: SC035

Dominant Wetland Strat.

Plant Indicator

Species Status

$\begin{array}{lll}\text { POPTRE } & \text { FAC } & \text { T } \\ \text { SYMALB } & \text { FACU } & \text { S } \\ \text { ROSWOO } & \text { FACU } & \text { S } \\ \text { ELYGLA } & \text { FACU } & \text { H } \\ \text { OSMOCC } & \text { FAC } & \text { H }\end{array}$

FAC $\mathrm{H}$

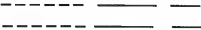

$-----\square$

------ $\square-$

------ -

$----\square-\square$

-ーー-ーー $-\square-\square-$

------ -

Percent of Dominant Spp .

That Are:

$$
\text { OBL: } 0
$$

FACW: 0

FAC+/FAC: 40

Total \% Wetind. Spp. 40 Hydroph. Veg. $Y: \quad N: x$ Hydric Soil: $\quad Y:-N: X$ Wtind. Hydro. $\mathrm{Y} ; \mathrm{N}: \mathrm{X}$

Jurisdic. Wtind. $\mathrm{Y}: \ldots \mathrm{N}: \mathrm{x}$
Plot Number: $\mathrm{Sc036}$

Dominant Wetland Strat.

Plant Indicator

Species Status

$\begin{array}{lll}\text { POPTRE } & \text { FAC } & \text { T } \\ \text { POPOTRI } & \text { FACW } & \text { T } \\ \text { ROSWOO } & \text { FACU } & \text { S } \\ \text { ELYGLA } & \text { FACU } & \text { H } \\ \text { OSMOCC } & \text { FAC } & \text { H } \\ \text { SENPSE } & \text { FACW } & \text { H }\end{array}$
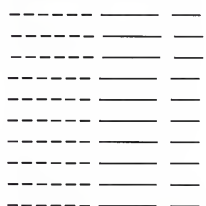

- -

Percent of Dominant Spp. That Are:

OBL: 0

FACW: 33

FAC+/FAC: 33

Total \% Wetlnd. Spp. 67 Hydroph. Veg. Y: $x$ N: Hydric Soil: Y:? N:Wtind. Hydro. Y: ? N:-

Jurisdic. Wtind. Y: ? N:

* Federal Manual for Identifying and Delineating Jurisdictional Wetlands (1987) 

Appendix G (Continued). Application of comprehensive onsite determination method ${ }^{\star}$ to selected trembling aspen-black cottonwood stands.

Plot Number: SC037

\begin{tabular}{|c|c|}
\hline $\begin{array}{l}\text { Dominant } \\
\text { Plant } \\
\text { Species }\end{array}$ & $\begin{array}{l}\text { Wetland } \\
\text { Indicator } \\
\text { Status }\end{array}$ \\
\hline $\begin{array}{l}\text { POPTRE } \\
\text { POPTRI } \\
\text { SYMALB } \\
\text { RUBPAR } \\
\text { ELYGLA } \\
\text { OSMOCC } \\
\text { VIOCAN } \\
\text { HERLAN }\end{array}$ & $\begin{array}{l}\text { FAC } \\
\text { FACW } \\
\text { FACU } \\
\text { FACU } \\
\text { FACU } \\
\text { FAC } \\
\text { FAC } \\
\text { FAC }\end{array}$ \\
\hline $\begin{array}{l}------ \\
------ \\
------ \\
------ \\
------ \\
------ \\
------ \\
------\end{array}$ & \\
\hline
\end{tabular}

Percent of Dominant Spp. That Are:

$$
\text { OBL: } 0
$$

FACW: 12

\section{FAC+/FAC: 50}

Total \% Wetlnd. Spp. 62 Hydroph. Veg. Y: x N: Hydric Soil: $\quad Y: \times N$ : Wtind. Hydro. $\mathrm{Y}: \times \mathrm{N}:-$

Jurisdic. Wtind. $\mathrm{Y}: \times \mathrm{N}$ :

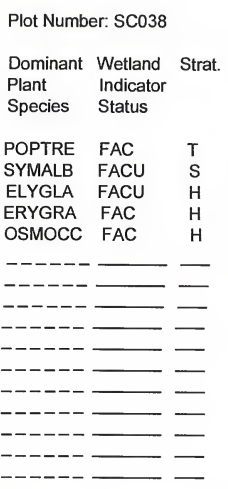

Percent of Dominant Spp. That Are:

$$
\text { OBL: } 0
$$

FACW: 0

FAC+/FAC: 60

Total \% WetInd. Spp. 60 Hydroph. Veg. Y: $x \mathrm{~N}$ :

Hydric Soil: $\quad Y:-N: \bar{x}$ Wtind. Hydro. $\mathrm{Y}: \mathrm{N}: \mathrm{x}$

Jurisdic. Wtind. $\mathrm{Y}: \mathrm{N}: \mathrm{X}$
Plot Number: SC039

$\begin{array}{ll}\text { Dominant } & \text { Wetland Strat. } \\ \text { Plant } & \text { Indicator } \\ \text { Species } & \text { Status }\end{array}$

POPTRE FAC T

ROSWOO FACU S

ALOALP FACW $\mathrm{H}$

CALSTR FACW H

PHLPRA FAC H

GEUMAC FACW+ $\mathrm{H}$

SENFOE FACW- $\mathrm{H}$

$------\square$

$-----\square$

$------$

$------\longrightarrow$

$------\square-$

-----ー $-\square$

Percent of Dominant Spp. That Are:

\section{OBL: 0}

FACW: 57

FAC+/FAC: 29

Total \% Wetlnd. Spp. 86 Hydroph. Veg. Y: $x$ N:_ Hydric Soil: Y: ? N:Wtind. Hydro. Y: $\times \mathrm{N}:-$

Jurisdic. Wtind. $\mathrm{Y}: \times \mathrm{N}$ :

\begin{tabular}{|c|c|c|}
\hline $\begin{array}{l}\text { Dominant } \\
\text { Plant } \\
\text { Species }\end{array}$ & $\begin{array}{l}\text { Wetland } \\
\text { Indicator } \\
\text { Status }\end{array}$ & Strat. \\
\hline $\begin{array}{l}\text { POPTRE } \\
\text { RUBPAR } \\
\text { SYMALB } \\
\text { ELYGLA } \\
\text { ERYGRA } \\
\text { THAOCC } \\
\text { VIOCAN }\end{array}$ & $\begin{array}{l}\text { FAC } \\
\text { FACU } \\
\text { FACU } \\
\text { FACU } \\
\text { FAC } \\
\text { FACU } \\
\text { FAC }\end{array}$ & $\begin{array}{l}T \\
S \\
S \\
H \\
H \\
H \\
H\end{array}$ \\
\hline $\begin{array}{l}----ー-~ \\
------ \\
------ \\
------ \\
------ \\
------ \\
------ \\
------\end{array}$ & & 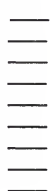 \\
\hline
\end{tabular}

Plot Number: $\mathrm{SC} 040$

Percent of Dominant Spp . That Are:

OBL: 0

FACW: 0

\section{FAC+/FAC: 42}

Total \% Wetlnd. Spp. 42

Hydroph. Veg. Y: $-\mathrm{N}: \mathrm{X}$ Hydric Soil: $\quad Y:-N: x$ Wtind. Hydro. $\mathrm{Y}: \mathrm{N}: \mathrm{X}$

Jurisdic. Wtind. $\mathrm{Y}: \ldots \mathrm{N}: \mathrm{x}$
Plot Number: SC041

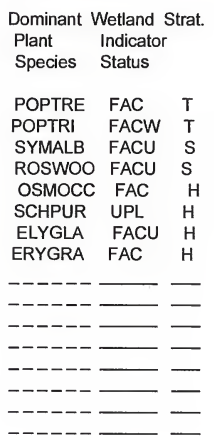

Percent of Dominant Spp. That Are:

OBL: 0

FACW: 12

FAC+/FAC: 37

Total \% Wetlnd. Spp. 50 Hydroph. Veg. Y: x N: x Hydric Soil: $\quad Y:-N: x$ Wtind. Hydro. $\mathrm{Y}: \mathrm{N}: \mathrm{x}$

Jurisdic. Wtind. $\mathrm{Y}: \ldots \mathrm{N}: \mathrm{x}$

* Federal Manual for Identifying and Delineating Jurisdictional Wetlands (1987) 

Appendix $\mathrm{G}$ (Continued). Application of comprehensive onsite determination method ${ }^{\mathrm{t}}$ to selected trembling aspen-black cottonwood stands.

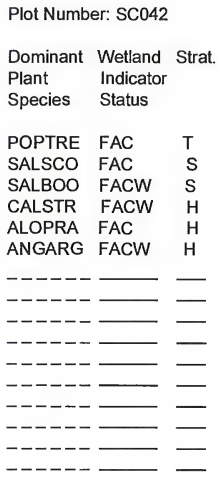

Percent of Dominant Spp. That Are:

$$
\text { OBL: } 0
$$

FACW: 50

\section{FAC+/FAC: 50}

Total \% Wetlnd. Spp. 100 Hydroph. Veg. Y: $x$ N: Hydric Soil: $\quad \mathrm{Y}: \mathrm{x} \mathrm{N}:-$ Wtind. Hydro. Y: $x \mathrm{~N}$ :-

Jurisdic. Wtind. Y: x N:
Plot Number: SC043

\begin{tabular}{|c|c|c|c|c|c|}
\hline $\begin{array}{l}\text { Dominant } \\
\text { Plant } \\
\text { Species }\end{array}$ & $\begin{array}{l}\text { Wetland } \\
\text { Indicator } \\
\text { Status }\end{array}$ & Strat. & $\begin{array}{l}\text { Dominant } \\
\text { Plant } \\
\text { Species }\end{array}$ & $\begin{array}{l}\text { Wetland } \\
\text { Indicator } \\
\text { Status }\end{array}$ & Strat. \\
\hline POPTRE & FAC & $\mathrm{T}$ & POPTRI & FACW & $\mathrm{T}$ \\
\hline POPTRI & FACW & $\mathrm{T}$ & POPTRE & FAC & $\mathrm{T}$ \\
\hline RUBPAR & FACU & S & ROSWOO & FACU & $s$ \\
\hline DISHOO & $\mathrm{NI}$ & $\mathrm{H}$ & AMEALN & FACU & S \\
\hline ACTRUB & $\mathrm{NI}$ & $\mathrm{H}$ & ELYGLA & FACU & $\mathrm{H}$ \\
\hline VIOCAN & FAC & $\mathrm{H}$ & CALRUB & NIT & $\mathrm{H}$ \\
\hline HERLAN & FAC & $\mathrm{H}$ & OSMOCC & FAC & $\mathrm{H}$ \\
\hline----- & & $\longrightarrow$ & THAOCC & FACU & $\mathrm{H}$ \\
\hline---- & & $\longrightarrow$ & ------ & & - \\
\hline---- & & - & -- & & - \\
\hline $\begin{array}{l}---- \\
----1\end{array}$ & & - & --ー-ー- & & - \\
\hline---1 & & $\overline{ }$ & $\begin{array}{l}---- \\
----\end{array}$ & & - \\
\hline--- & & - & ---- & & 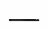 \\
\hline--- & & - & ------ & & \\
\hline
\end{tabular}

Percent of Dominant Spp. That Are:

$$
\text { OBL: } 0
$$

FACW: 14

FAC+/FAC: 43

Total \% Wetlnd. Spp. 57 Hydroph. Veg. Y: X N: Hydric Soil: $\quad \mathrm{Y}: \times \mathrm{N}:-$ Wtind. Hydro. Y: ? N:-

Jurisdic. WtInd. Y: ? N:

Percent of Dominant Spp. That Are:

\section{OBL: 0}

FACW: 12

FAC+/FAC: 25

Total \% Wetind. Spp. 37 Hydroph. Veg. Y: $N$ N: $\mathbf{x}$ Hydric Soil: $\quad Y:-N: x$ Wtind. Hydro. $\mathrm{Y}: \bar{?} \mathrm{~N}$ :
Dominant Wetland Strat.

Jurisdic. Wtind. $\mathrm{Y}:[\mathrm{N}: \mathrm{x}$
Plot Number: SC045

Plant Indicator

Species Status

$\begin{array}{lll}\text { POPTRE } & \text { FAC } & \text { T } \\ \text { ROSWOO } & \text { FACU } & \text { T } \\ \text { SALBOO } & \text { FACW } & \text { S } \\ \text { PHLPRA } & \text { FACU } & \text { H } \\ \text { POAPRA } & \text { FACU } & \text { H } \\ \text { ELYGLA } & \text { FACU } & \text { H } \\ \text { ALOPRA } & \text { FACW } & \text { H } \\ \text { TAROFF } & \text { FACU } & \text { H } \\ \text { SENPSE } & \text { FACW } & \text { H } \\ ------ & & - \\ ------ & & - \\ ------ & & - \\ ------ & & - \\ ------ & - & -\end{array}$

Plot Number: SC046

Dominant Wetland Strat.

Plant Indicator

Species Status

$\begin{array}{lll}\text { POPTRE } & \text { FAC } & \text { T } \\ \text { POPTRI } & \text { FACW } & \text { T } \\ \text { ROSWOO } & \text { FACU } & \text { S } \\ \text { AMEALN } & \text { FACU } & \text { S } \\ \text { SYMALB } & \text { FACU } & \text { S } \\ \text { ELYGLA } & \text { FACU } & \text { H } \\ \text { ALOPRA } & \text { FACW } & \text { H } \\ \text { PHLPRA } & \text { FACU } & \text { H } \\ \text { SENFOE } & \text { FACW } & \text { H } \\ \text { FRAVIR } & \text { FACU } & \text { H } \\ \text { ANGARG } & \text { FACW } & \text { H }\end{array}$

Percent of Dominant Spp . That Are:

OBL: 0

FACW: 33

FAC+/FAC: 11

Total \% Wetlnd. Spp. 44

Hydroph. Veg. Y: $N$ : X

Hydric Soil: $\quad Y:-N: x$

Wtind. Hydro. $\mathrm{Y}:-\mathrm{N}: \mathrm{x}$

Jurisdic. Wtind. $\mathrm{Y}: \mathrm{N}_{\mathrm{N}} \mathrm{X}$

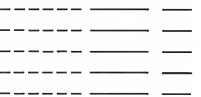

Percent of Dominant Spp. That Are:

OBL: 0

FACW: 36

FAC+/FAC: 09

Total \% Wetlnd. Spp. 45 Hydroph. Veg. Y: $-\mathrm{N}: \mathrm{x}$ Hydric Soil: $\quad Y: \bar{X} N$ : Wtind. Hydro. Y: $\times$ N: Jurisdic. Wtind. $\mathrm{Y}: \times \mathrm{N}$ :

* Federal Manual for Identifying and Delineating Jurisdictional Wetlands (1987) 

Appendix $\mathrm{G}$ (Continued). Application of comprehensive onsite determination method ${ }^{\star}$ to selected trembling aspen-black cottonwood stands.

Plot Number: SC047

Dominant Wetland Strat.

Plant Indicator

Species Status

\begin{tabular}{lll} 
POPTRE & FAC & $\mathrm{T}$ \\
POPTRI & FACW & $\mathrm{T}$ \\
SYMALB & FACU & $\mathrm{S}$ \\
AMEALN & FACU & $\mathrm{S}$ \\
POAPRA & FACU & $\mathrm{H}$ \\
GERRIC & FACU+ & $\mathrm{H}$ \\
PHLPRA & FACU & $\mathrm{H}$ \\
FRAVIR & FACU & $\mathrm{H}$ \\
ANGARG & FACW & $\mathrm{H}$ \\
VIOCAN & FAC & $\mathrm{H}$ \\
------ & & - \\
------ & & - \\
----- & - & - \\
\hline------ & - & - \\
----- & - & -
\end{tabular}

Percent of Dominant Spp.

That Are:

$$
\text { OBL: } 0
$$

FACW: 20

FAC+/FAC: 20

Total \% Wetlnd. Spp. 40 Hydroph. Veg. Y: $-N: X$ Hydric Soil: $\quad \mathrm{Y}:-\mathrm{N}: \mathrm{X}$ Wtind. Hydro, $Y:-N: x$

Jurisdic. WtInd. Y:_N: $\mathrm{X}$
Plot Number: SC048

Dominant Wetland Strat.

Plant Indicator

Species Status

$\begin{array}{lll}\text { POPTRE } & \text { FAC } & \text { T } \\ \text { POPTRI } & \text { FACW } & \text { T } \\ \text { SALBEB } & \text { FACW } & \text { S } \\ \text { SYMALB } & \text { FACU } & \text { S } \\ \text { CALCAN } & \text { FACW } & \text { H } \\ \text { ALOALP } & \text { FACW } & \text { H } \\ \text { SYMALB } & \text { FACU } & \text { S }\end{array}$

-----D - -

$-----\square-$

$------$

--・-ー- $\square-$

$----\square-$

$------\square$

------

Percent of Dominant Spp.

That Are:

OBL: 0

FACW: 57

FAC+/FAC: 29

Total \% Wetlnd. Spp. 86 Hydroph. Veg. Y: $x \mathrm{~N}$ : Hydric Soil: Y: $x \mathrm{~N}:-$ Wtind. Hydro. $\mathrm{Y}: \times \mathrm{N}:-$

Jurisdic. Wtind. $\mathrm{Y}: \mathrm{x} \mathrm{N}$ :-
Plot Number: SC049

Dominant Wetland Strat.

Plant Indicator

Species

Status

POPTRI FACW T

POPTRE FAC T

ROSWOO FACU S

SYMALB FACU S

BROCIL FAC+ $\mathrm{H}$

OSMOCC FAC $\mathrm{H}$

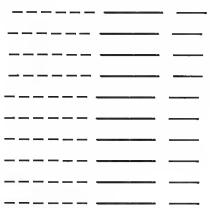

Percent of Dominant Spp. That Are:

\section{OBL: 0}

FACW: 12

FAC+/FAC: 50

Total \% Wetlnd. Spp. 62 Hydroph. Veg. Y: x N: Hydric Soil: $\quad \mathrm{Y}: \mathrm{N}: \overline{\mathrm{x}}$ Wtind. Hydro. $Y:-N: X$

Jurisdic. Wtind. $\mathrm{Y}: \ldots \mathrm{N}: \mathrm{x}$
Plot Number: SC050

Dominant Wetland Strat.

Plant Indicator

Species Status

$\begin{array}{lll}\text { POPTRI } & \text { FACW } & \text { T } \\ \text { POPTRE } & \text { FAC } & \text { T } \\ \text { GERRIC } & \text { FACU+ } & \text { S } \\ \text { FRAVIR } & \text { FACU } & \text { H } \\ \text { SALSCO } & \text { FAC } & \text { S }\end{array}$

SALSCO FAC S

------ $----\square$

$-----\square$

------ $\square-$

$-$

- - - - -

- - - - -

- - - - -

- - - -

- - - -

Percent of Dominant Spp . That Are:

OBL: 0

$$
\text { FACW: } 20
$$

FAC+/FAC: 40

Total \% Wetlnd. Spp. 60 Hydroph. Veg. Y: $x$ N: Hydric Soil: $\quad \mathrm{Y}: \times \mathrm{N}$ :

Wtind. Hydro. Y: $x$ N:-

Jurisdic. Wtind. Y: $x \mathrm{~N}$ :
Plot Number: SC051

Dominant Wetland Strat.

Plant Indicator

Species Status

$\begin{array}{lll}\text { POPTRE } & \text { FAC } & \text { T } \\ \text { POPTRI } & \text { FACW } & \text { T } \\ \text { SALBEB } & \text { FACW } & \text { S } \\ \text { SYMALB } & \text { FACU } & \text { S } \\ \text { AMEALN } & \text { FACU } & \text { S } \\ \text { ROSWOO } & \text { FACU } & \text { S } \\ \text { PHLPRA } & \text { FACU } & \text { H } \\ \text { POAPAL } & \text { FACW } & \text { H } \\ \text { ALOALP } & \text { FACW } & \text { H } \\ \text { POAPR } & \text { FACU } & \text { H } \\ \text { SANMAR } & \text { NI } & \text { H } \\ \text { ANGARG } & \text { FACW+ } & \text { H } \\ ------ & & - \\ ----- & & - \\ ----- & - & -\end{array}$

Percent of Dominant Spp. That Are:

OBL: 0

FACW: 42

FAC+/FAC: 08

Total \% WetInd. Spp. 50 Hydroph. Veg. Y: $x$ N: $x$ Hydric Soil: $Y: X N$ : Wtind. Hydro. Y: ? N:Jurisdic. Wtind. Y: $\times \mathrm{N}$ : 

Appendix $\mathrm{G}$ (Continued). Application of comprehensive onsite determination method* to selected trembling aspen-black cottonwood stands.

Plot Number: SC052

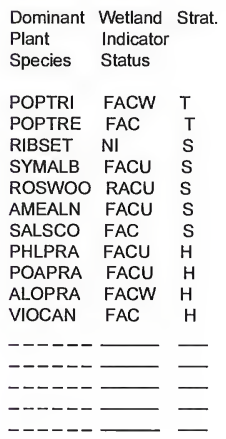

Percent of Dominant Spp. That Are:

OBL: 0

FACW: 18

FAC+/FAC: 18

Total \% Wetlnd. Spp. 36 Hydroph. Veg. Y: N: $\mathrm{X}$ Hydric Soil: $\quad \mathrm{Y}: \mathrm{N}: \mathrm{X}$ Wtind. Hydro. $\mathrm{Y}: \overline{\mathrm{T}} \mathrm{N}$ :

Jurisdic. Wtind. $\mathrm{Y}:-\mathrm{N}: \mathrm{X}$
Plot Number: SCO53

$\begin{array}{llll}\text { Dominant } & \text { Wetland Strat. } & \text { Dominant } & \text { Wetland Strat. } \\ \text { Plant } & \text { Indicator } & \text { Plant } & \text { Indicator } \\ \text { Species } & \text { Status } & \text { Species } & \text { Status }\end{array}$

POPTRE FAC T

RUBPAR FACU S

OSMOCC FAC H

ELYGLA FACU H

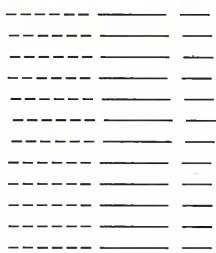

Percent of Dominant Spp.

That Are:

$$
\text { OBL: } 0
$$

FACW: 0

FAC+/FAC: 50

Total \% Wetlnd. Spp. 50

Hydroph. Veg. Y: $x$ N: X

Hydric Soil: $\quad Y:-N: x$

Wind. Hydro. $Y:-N: x$

Jurisdic. WtInd. Y:_ N: X

\section{Plot Number: Plot Number:}

$\begin{array}{ll}\text { Dominant } & \text { Wetland Strat } \\ \text { Plant } & \text { Indicator } \\ \text { Species } & \text { Status }\end{array}$

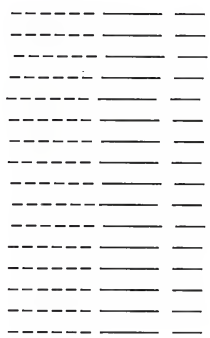

Percent of Dominant Spp. That Are:

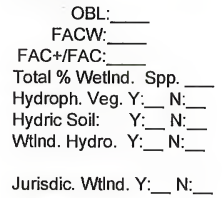

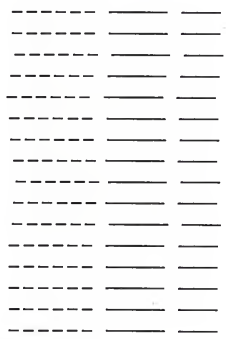

Percent of Dominant Spp . That Are:

$$
\text { OBL: }
$$

FAC+/FAC:

Total \% Wetind. Spp.

Hydroph. Veg. Y: $-\mathrm{N}:-$ Hydric Soil: $\mathrm{Y}:-\mathrm{N}$ :

Wtind. Hydro. $\mathrm{Y}: \mathrm{N}:-$

Jurisdic. Wtind. $\mathrm{Y}:$
Plot Number:

Dominant Wetland Strat.

Plant Indicator

Species Status

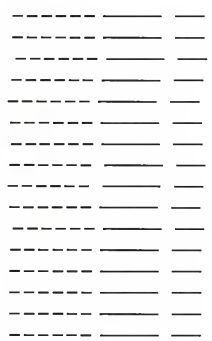

Percent of Dominant Spp. That Are:

$$
\begin{aligned}
& \text { OBL: } \\
& \text { FACW: }
\end{aligned}
$$

FAC+/FAC:

Total \% Wetlind. Spp. Hydroph. Veg. Y: $\mathrm{N}:-$ Hydric Soil: $\quad \mathrm{Y}: \mathrm{N}:-$ Wtind. Hydro. $\mathrm{Y}:-\mathrm{N}:-$ Jurisdic. Wtind. $\mathrm{Y}: \mathrm{N}_{\mathrm{N}}$

* Federal Manual for Identifying and Delineating Jurisdictional Wetlands (1987) 



\title{
APPENDIX $\mathrm{H}$. \\ COMMUNITY SURVEY FORM (MTNHP) \\ GENERAL PLOT DATA:
}

\author{
IDENTIFICATION AND LOCATION: \\ MANUAL: \\ UNITS: _ft. _m \\ PLOT NO. \\ EXAMNER(S): \\ POT. NAT. COMM. \\ :MON.__DAY: _ YEAR: _-_ EOCODE: \\ SITE NAME: \\ PURP: \\ PREC: \\ QUAD NAME: \\ LEGAL: \\ $\mathrm{T}$; \\ $\mathrm{R}$; _ S $\quad \mathrm{I} / \mathrm{4S}$ \\ C.T.: \\ LATITUDE: \\ (deg.);__ ( \\ PLOT TYPES: \\ PLOT SIZE: \\ PHOTOGRAPHY: \\ DIRECTIONS: \\ STATE \\ $\overline{\text { QUAD }}$ CODE: \\ 4/4; 4/4/4 COMM. SIZE (acres): \\ (sec.) LONGITUDE: _(deg.) (min.); \\ RADIUS/LN; — WIDTH SURVEY: \\ (sec.) \\ WIDTH SURVEY:
}

\section{CONSERVATION RANRING:}

CONDITION:

VIABILITY:

DEFENSIBL:

RANK:

COMMENT:

COMMENT:

COMMENT:

MANAGEMENT:

COMMENT:

PROTECTION :

\section{ENVIRONMENTAL FEATURES:}

DL: SOIL RPT:

SOIL UNIT: SOIL TAXON:

PARENT MAT:: LANDFORM: ASPECT(०): - SLOPE (\%): _- ELEVATION: HORIZON ANGLE: $\bar{N}$ SPECIAL FEATURE(S): GROUND COVER (classes): _ sOI $+\ldots$ GRVVE $+\ldots$ ROCK $+\ldots$ LITTER $+\ldots$ WOOD $+\ldots$ MOSS $+\ldots$ BASNL VEG $+\ldots$ OTHER $=100 \%$ DISTURBANCE HISTORY (type, intensity, frequency, season):

DISTUBANCE HSTORY (type, intensity, frequency, season):

\section{RIPARIAN FEATURES: NONE:} SURFACE WATER DEPTH: WETLAND FEATURES: NONE: DEPTH (cm or in., observed): PONDING EVIDENCE: DURATION OF INUNDATION: CAPILLARY FRINGE: ORGANIC HORIZON THICKNESS (cm or in.): CHANNEL WIDTH: HEIGHT ABOVE WATR: COWARDIN CLASSIFICATION: CHANNEL ENTRENCH.: DIST. FROM WATR.: $\overline{M E A N}$ MAXIMUM AVE ANN HIGH WATER

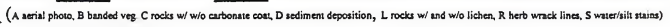
(days, this year) DEPTH TO CAP. FRNGE; SEDIMENT DEPOSITION: COVER (\%), THICKNESS CAP. FRINGE; MEPTH (cm or in.) $\mathrm{MN}$.__ MAX; _ Oa

\section{$\overline{\text { GENERAL SITE DESCRIPTION (landscape features, position in landscape, and position on catena, adjacent c.ts., disease, etc.): }}$}





\section{APPENDIX I. \\ OCULAR PLANT SPECIES DATA:}

PLOT NUMBER:

NO. SPECIES

PNC:

MINIMUM COVER VALUE:

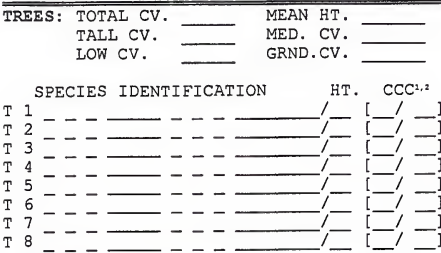

\section{SHRUBS: TOTAL CV TALL CV. LOW CV.}

S 1

$\mathrm{S}$

$S$

54

S 5

S 6

s 7

$\mathrm{S} 8$

59

S10

S11

S12

GRAMINOIDS: TOT. CV. MED. CV. GRND. CV

G 1

G 2

G 3

G

G 5 - - -

G $6---$

G 7

G

G 9

G10

G11

G12

G13

G14

G15

G16
MEAN HT

MED CV.

GRND.CV .

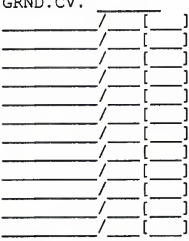

MEAN HT. LOW CV.

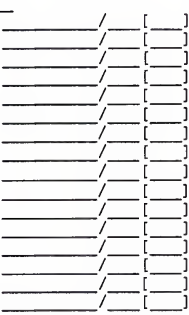

FORBS: TOTAL CV.

MED. CV.

GRND. CV.
MEAN HT

LOW CV.
SPECIES IDENTIFICATION

] 1

F 2

F $3---$

F 4

E 5

F $6--$

F $7--$

F 8

F 9

F10

F11

F12

F13

F14

F15

F16

F17

F18

F19

F20

F21

F22

F23

F24

F25

F26

F27

F28

F29

F30

F31

F 32

F33

F34

F35

F36

FERNS $\bar{A} N \bar{D}$ ALIIED FORMS:

TOTAL CV. MEAN HT.

LOW CV.

GRND CV.

\section{F 1}

F 2

F 3

$\begin{array}{ll}F & 4 \\ F & 5\end{array}$
HT. CCC

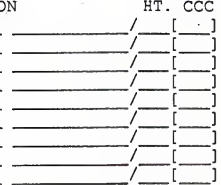

BRYOIDS: TOTAL CV.
B 1
B 3
B 5
B 7

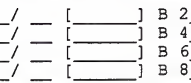

COMMENTS (EODATA)

2 Tree canopy cover for mature ( 5 in. dbh) and seedlings/saplings ( 5 in. dbh.)

1 Canopy Cover Classes (Percent Values): $0 ; T=0,<1 ; P=21,<5 ; 1=25,<15 ; 2=215,<25 ; 3=225,<35 ;$

$4=235,<45 ; 5=245,<55 ; 6=255,<65 ; 7=265,<75 ; 8=275,<85 ; 9=285,<95 ; F=295$ 

Appendix J.

Annotated photographs documenting examples of the Populus tremuloides / Cornus stolonifera, P. tremuloides / Calamagrostis canadensis, and $P$. tremuloides / Osmorhiza occidentalis plant associations. 



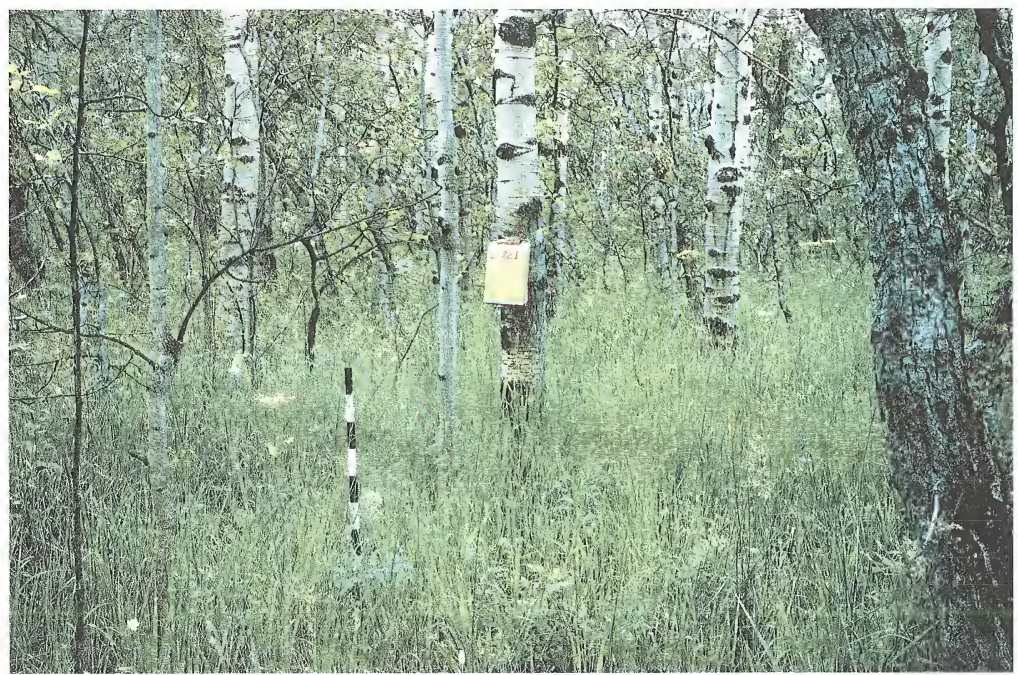

Popu/us tremuloides / Calamagrostis canadensis plant association: A multi-aged structure is apparent with $P$. tremuloides dominant in all layers; $C$. canadensis and Alopecurus alpinus form a tall sward mostly obscuring the dominant forbs Angelica arguta, Seneclo pseudaureus, and Geum macrophyllum. 


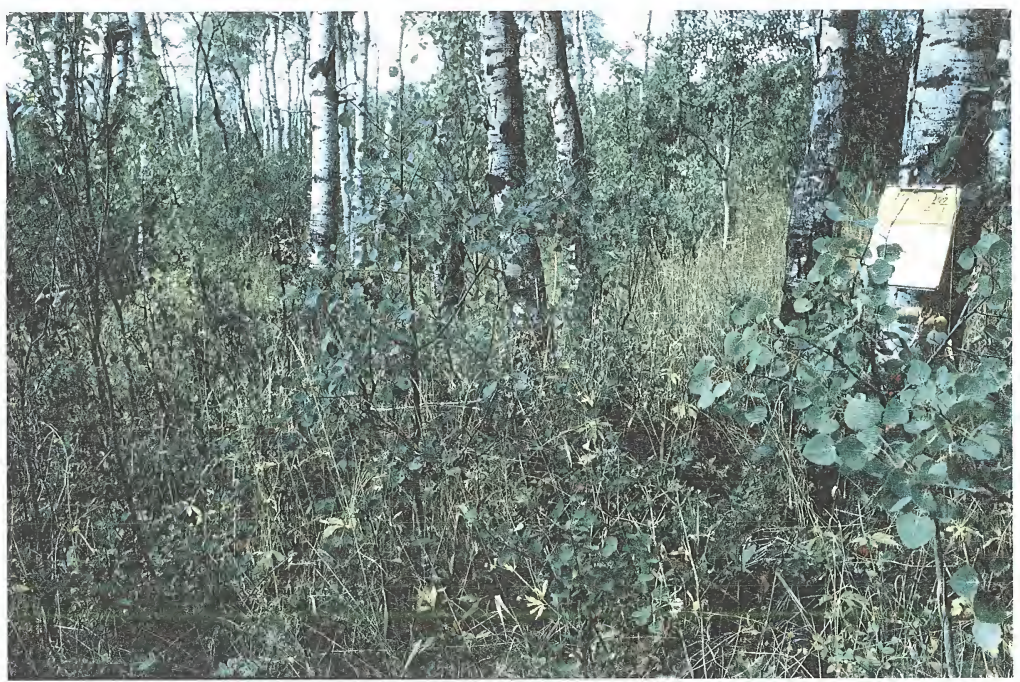

Populus tremuloides / Calamagrostis canadensis plant association: In contrast to previous stand of this p. a., this stand is primarily two-aged; the canopy is experiencing high mortality. Although the shrub component is significant, three grasses dominate the undergrowth: $C$. canadensis, Alopecurus pratensis, and Poa pratensis. 



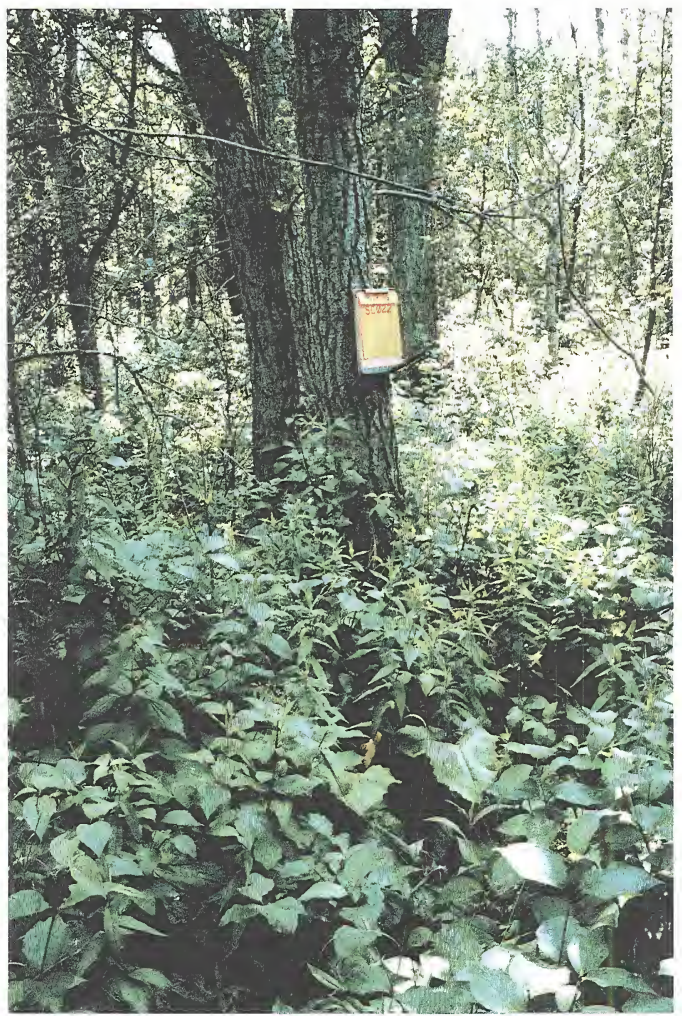

Populus tremuloides / Cornus stolonifera plant association: Upper canopy is dominated by $P$. trichocarpa with $P$. tremuloides ascendant in the understory; dominating the undergrowth are $C$. stolonifera (shrub layer) and forbs Angelica arguta, Heracleum lanatum and Sanicula marilandica. 



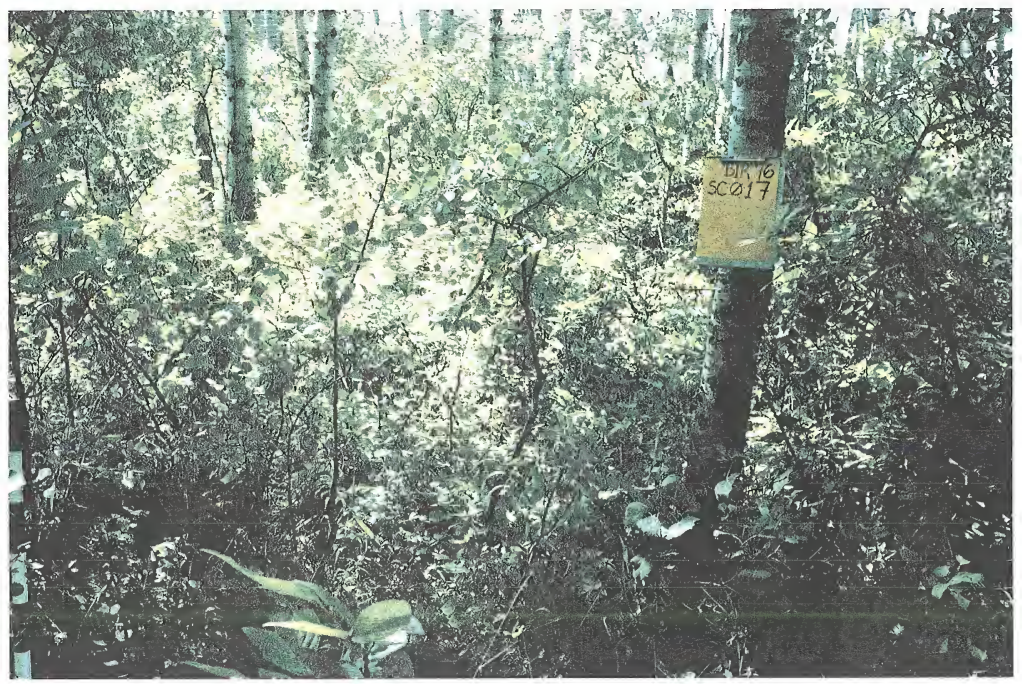

Populus tremuloides / Cornus stolonifera plant association: Abundant $P$. tremuloides reproduction combined with high coverage of Cornus stolonifera and Symphoricarpos albus result in a dense undergrowth. 


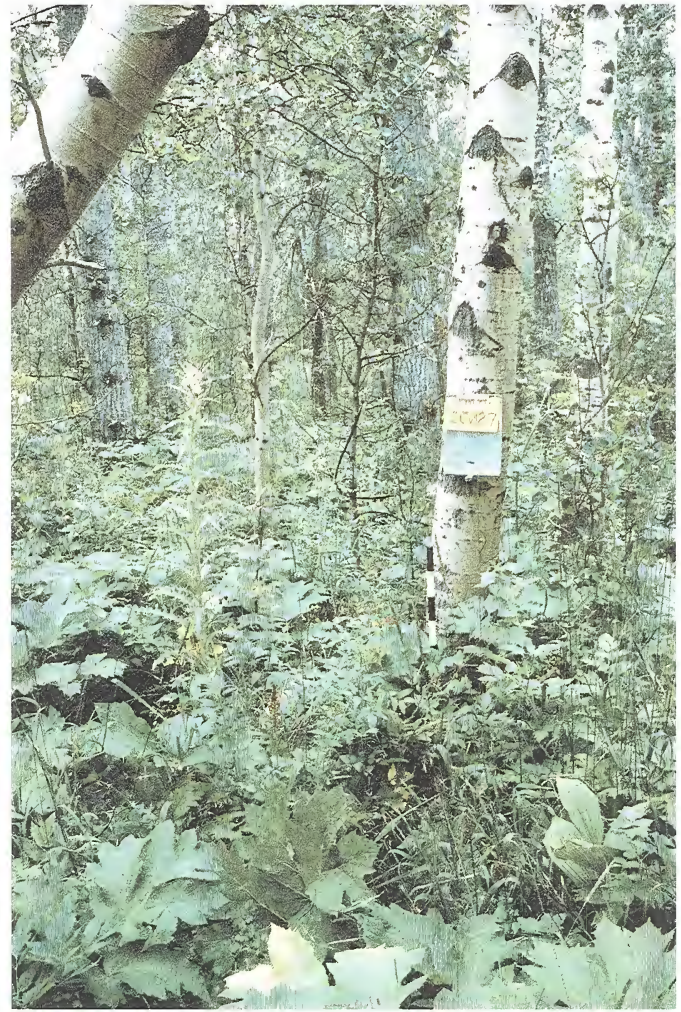

Populus tremuloides / Osmorhiza occidentalis plant association: Tree dominance shared between $P$. trichocarpa and $P$. tremuloides on this site that is unequivocally a wetland; the undergrowth is species rich with over 40 represented, the dominants being Heracleum lanatum, Veratrum viride, and Elymus glaucus. 


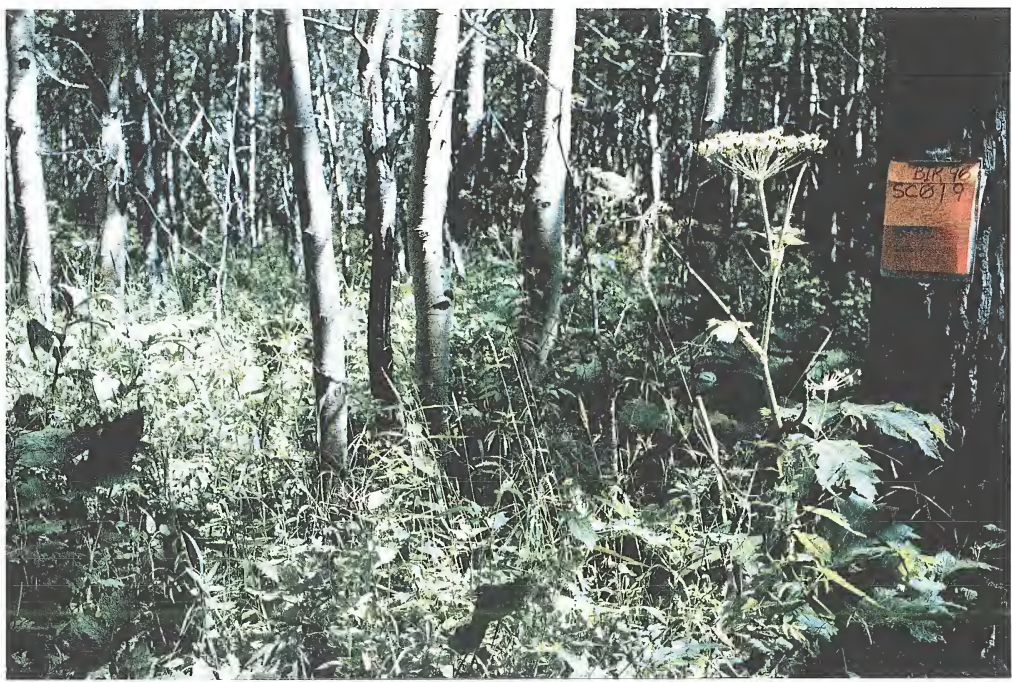

Populus tremuloides / Osmorhiza occidentalis plant association: This even-aged wetland stand is dominated by $P$. tremuloides in the overstory. The dominance of herbs Heracleum lanatum, O. occidentalis, Elymus glaucus and others $(135 \%$ combined cover) obscures the shrubs, which have a combined cover of $40 \%$. 


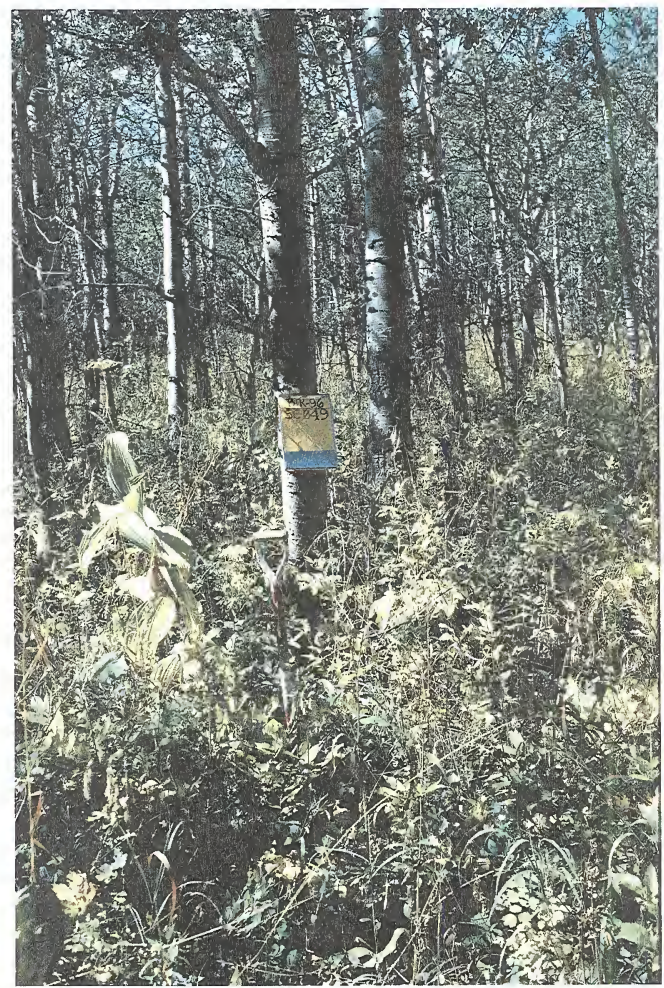

Populus tremuloides / Osmorhiza occidentalis plant association: This upland site is approaching autumnal coloration in late August; the undergrowth is dominated by the native rhizomatous grasses Elymus glaucus, Bromus ciliatus, and Festuca subulata, and by the forb 0 . occidentalis. 
